UNIVERSIDADE DE SÃO PAULO

INSTITUTO DE GEOCIÊNCIAS

ATIVIDADES AGRÍCOLAS E PROTEÇÃO CILIAR NA PORÇÃO LESTE DO RESERVATÓRIO DE BIRITIBA MIRIM (SP) E SUA IMPLICAÇÃO NA QUALIDADE DA ÁGUA E SEDIMENTOS DE FUNDO

\title{
Edvaldo Sorrini
}

Orientador: Prof. Dr. Joel Barbujiani Sígolo

\section{DISSERTAÇÃO DE MESTRADO}

Programa de Pós-Graduação em Recursos Minerais e Hidrogeologia

\author{
Versão Corrigida \\ SÃO PAULO \\ 2015
}


Autorizo a reprodução e divulgação total ou parcial deste trabalho, por qualquer meio convencional ou eletrônico, para fins de estudo e pesquisa, desde que citada a fonte.

Ficha catalográfica preparada pelo Serviço de Biblioteca e Documentação do Instituto de Geociências da Universidade de São Paulo

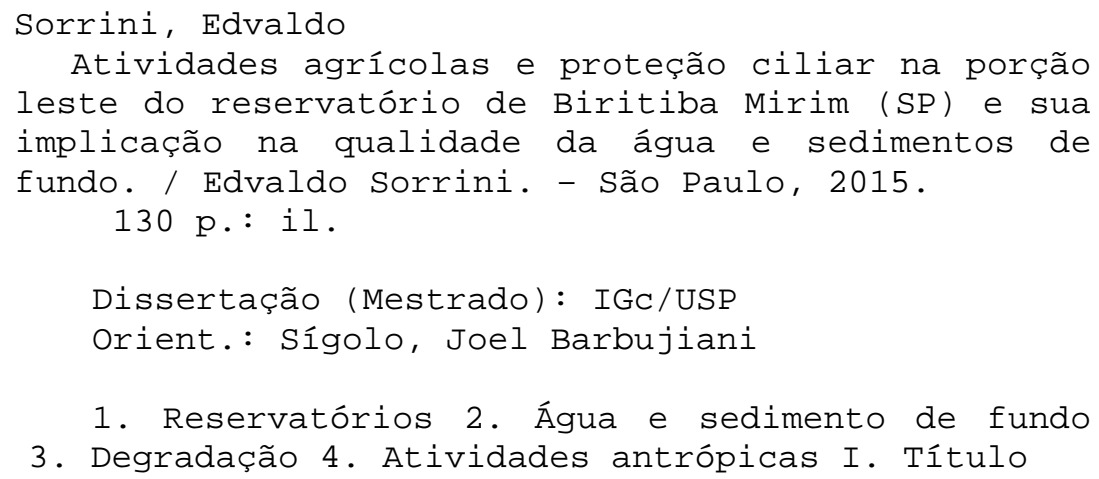


Dedico esse trabalho aos meus pais, minha esposa Regina e especialmente a minha filhota Taísi pelo incentivo e sentido da vida. 


\section{AGRADECIMENTOS}

A Deus, pela oportunidade da vida com saúde, pelo discernimento, amor, sabedoria e paz, pela minha família, pela graça de realizar o sonho do Mestrado.

Ao Prof. Dr. Joel Barbujiani Sígolo, pela oportunidade da orientação sem preconceitos, pela amizade, pelo incentivo, pela paciência, e por sempre acreditar que era possível. Obrigado também pelo apoio do seu técnico Samuel nos trabalhos de campo.

A minha esposa Regina e a minha filhota Taísi, pelo amor e apoio incondicional de sempre, e para realização desse sonho.

Agradecimento especial aos meus pais Alberto e Esperança, pela luta e dedicação, pela criação, educação, índole, humildade, caráter e princípios.

Ao engenheiro Pimentel, grande amigo, pelo apoio, compreensão e incentivo nas horas mais difíceis.

A engenheira Camila Kauling, pela amizade e disponibilidade em ajudar sempre.

Ao engenheiro Thomas Vianna pela contribuição.

Ao geógrafo Maurício Silva, pela amizade e colaboração técnica.

A engenheira Dra. Ana Lúcia, pela grande amizade, lealdade, disponibilidade e ajuda incondicional.

A equipe da SABESP do Sistema Alto Tietê: Ao meu amigo e Gerente Rodrigo Ferraz, aos técnicos Maurício e João Donizete, pelas informações, equipamentos, logística e toda infraestrutura para realização das amostragens na Represa de Biritiba-Mirim.

A equipe do DAEE da Barragem de Biritiba-Mirim: Diretor José Benedito, engenheiro Luis Carlos, Joaquim, Eder e Tiago, pelo apoio e disponibilidade em sempre ajudar. A Dra. Veridiana do IGc e ao Dr. José Guilherme da UNIFESP, pelas considerações importantes no exame de qualificação.

Ao químico Adilson Nunes, pelo apoio, informações e por disponibilizar a sonda multiparâmetro.

As colegas Camila e Ana nas amostragens.

Ao Laboratório de caracterização tecnológica (LCT) da Escola Politécnica da Universidade de São Paulo e equipe.

Agradeço também aqueles que direta ou indiretamente, contribuíram para realização desse sonho. 
"Tudo pode aquele que nele crê" Marcos 9:23 


\section{RESUMO}

SORRINI, E. Atividades agrícolas e proteção ciliar na porção leste do reservatório de Biritiba Mirim $(S P)$ e sua implicação na qualidade da água e sedimentos de fundo. 2015. 128 f. Dissertação (Mestrado) - Instituto de Geociências, Universidade de São Paulo, São Paulo, 2015.

O reservatório de Biritiba-Mirim (SP), um dos reservatórios do Sistema Produtor Alto Tietê, fornece água para aproximadamente 4 milhões de habitantes, principalmente para o leste da Região Metropolitana de São Paulo. Por localizar-se em uma região com grande pressão antrópica, o presente estudo objetivou a determinação de parâmetros físicos e químicos de água e de sedimentos de fundo em duas áreas a leste do reservatório de Biritiba-Mirim (SP), uma com atividade antrópica agrícola e outra em área protegida por mata ciliar. As amostras foram realizadas em número que permitiram um diagnóstico seguro da condição dessa área do reservatório. Nos mesmos locais foram amostradas alíquotas de água e sedimentos de fundo para análises químicas totais do conteúdo de elementos, buscando associar com compostos de degradação de rocha versus compostos utilizados em atividade agrícola, cinco pontos na área antrópica agrícola, cinco pontos na área protegida por mata ciliar e dois pontos, próximos a nascente do ribeirão Biritiba-Mirim. Os parâmetros utilizados para delimitar o padrão de qualidade, foram balizados pelos critérios do CONAMA e CETESB. Os resultados obtidos evidenciaram diferenças significativas nos parâmetros físico-químicos da água e dos sedimentos de fundo, entre as amostras realizadas nas áreas. Para água, mesmo que alguns resultados se apresentaram acima do padrão de qualidade, no ponto com proteção da mata ciliar, é evidente a presença de valores mais elevados dos elementos químicos analisados na área de estudo denominada antrópica agrícola. Para sedimentos de fundo, nenhum elemento químico analisado ultrapassou os padrões máximos de qualidade estabelecidos pelas legislações, e também se apresentaram mais elevados na área denominada antrópica agrícola, comparados com a área com proteção de mata ciliar. Essa observação também é válida quando os dados são comparados pela média de cada área. Comprovando que mesmo alguns elementos químicos se encontram presentes na composição do solo do Complexo Embu e também nos agroquímicos, a importância da proteção da mata ciliar e desse estudo.

Palavras-chave: Reservatório; Água e sedimento de fundo; Degradação; Atividades antrópicas. 


\begin{abstract}
SORRINI, E. Atividades agrícolas e proteção ciliar na porção leste do reservatório de Biritiba Mirim (SP) e sua implicação na qualidade da água e sedimentos de fundo. 2015. 128 f. Dissertação (Mestrado) - Instituto de Geociências, Universidade de São Paulo, São Paulo, 2015.
\end{abstract}

The reservoir Biritiba-Mirim (SP), one of the Alto Tietê Production System reservoirs, supplies water for approximately 4 million people, mainly to the east of Metropolitan Region of São Paulo. By locating in a region with high human pressure, this study aimed to determine the physical and chemical parameters of water and bottom sediments in two areas east of Biritiba-Mirim reservoir/SP, one with agricultural human activity and in another area protected by riparian vegetation. The samples were made in number to allow a safe diagnosis of the condition of the area of the reservoir. In the same sites were sampled aliquots of water and sediment from bottom to chemical analyzes of the content of total elements, seeking to associate with compounds degradation of rock versus compounds used in agricultural activity, five points in the anthropic area agricultural, five points in the area protected by riparian vegetation and two points, near the source of the stream Biritiba-Mirim. The parameters used to define the quality standard, were based by the criteria of CONAMA and CETESB. The results showed significant differences in physical and chemical parameters of water and bottom sediments, between the samples taken in the areas. For water, certain results presented above the quality standards, at the point with protection of riparian vegetation, evidencing the presence of higher levels of the chemical elements analyzed in the study area called anthropic agricultural. For bottom sediments, any chemical element analyzed exceeded the maximum quality standards established by legislation, and also they had higher in the area called anthropic agricultural, compared to the area with riparian protection. This observation is also valid when the data are compared by the mean of each area. Proving even that some chemical elements are present in the soil composition of Embu complex and also in agrochemicals, the importance of the protection of riparian forest and of this study.

Keywords: Reservoir; Water and bottom sediments; Degradation; Anthropic activities. 


\section{LISTA DE FIGURAS}

Figura 1 - Esquema de zonação longitudinal de um reservatório (COOKE et al.,2005)

Figura 2 - A importância das matas ciliares (Fonte: SMA, 2015) .35

Figura 3 - Unidade de Gerenciamento de Recursos Hídricos número 06 -UGHRI 06 (SIGRH, 2015).....

Figura 4 - Principais sub-bacias da bacia hidrográfica do Alto Tiete (Modificado de FIA, 2015). .43

Figura 5 - Sistemas Produtores da RMSP (SABESP, 2015) ................................4

Figura 6 - Sistema Produtor Alto Tietê - SPAT (SABESP, 2015) …........................46

Figura 7 - Perfil Hidráulico do Sistema Produtor do Alto Tietê (SABESP, 2015).......46

Figura 8 - Desenho esquemático do Sistema Alto Tietê (DAEE, 2015) ...................47

Figura 9 - Localização do município de Biritiba-Mirim no Estado de São Paulo

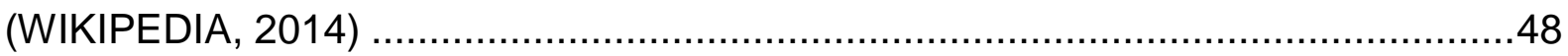

Figura 10 - Unidades geológicas na área de estudo (Fonte: Modificado de

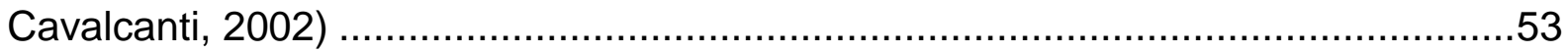

Figura 11 - Mapa hidrogeológico da área de estudo (Fonte: Modificado de Cavalcanti, 2002) .57

Figura 12 - Unidades geomorfológicas na área de estudo (Fonte: Modificado de Cavalcanti, 2002) 60

Figura 13 - Mapa de uso e ocupação do solo (Fonte: Modificado de Monteiro (2006, apud URAKAWA, 2011) .62

Figura 14 - Mapa de desapropriação. (Fonte: Modificado de FARIA, 2008) .63

Figura 15 - Mapa Florestal do Município de Biritiba-Mirim (SP) (SÃO PAULO, 2005)

Figura 16 - Imagem do LANDSAT 5 da Reservatório de Biritiba-Mirim (SP), com destaque das áreas de amostragens - (Fonte: MAPEIA, 2014) 69

Figura 17A e 17B - A - Visita a campo para reconhecimento da área de estudo. Fonte: J.B.Sígolo - $\quad$ B - Seleção dos pontos de amostragem e visita de parte do Ribeirão Biritiba-Mirim. Fonte: J.B.Sígolo. .70

Figura 18A e 18B - Área de amostragem protegida por Mata Ciliar. Fonte: E.Sorrini 
Figura 19 - Área de amostragem protegida por Mata Ciliar. Fonte: E.Sorrini. .71

Figura 20A e 20B - Área de amostragem denominada antrópica agrícola não protegida por mata ciliar e próxima da lâmina de água do reservatório. Fonte: E.Sorrini.

Figura 21 - Área de amostragem na cabeceira do Ribeirão Biritiba-Mirim, ponto referência e de recarga do reservatório. Fonte: E.Sorrini .71

Figura 22A e 22B - A - Marcação dos pontos de amostragens com sistema topofil no Reservatório de Biritiba-Mirim (SP). Fonte: E.Sorrini. B - Marcação dos mesmos pontos com bóias vermelhas. Fonte: J.B.Sígolo. .73

Figura 23 - Imagem do LANDSAT 5 do Reservatório de Biritiba-Mirim (SP), com destaque os pontos de amostragens na área com atividade agrícola (Fonte: MAPEIA, 2014).

Figura 24 - Imagem do LANDSAT 5 do Reservatório de Biritiba-Mirim (SP), com destaque os pontos de amostragens da área protegida por mata ciliar (Fonte: MAPEIA, 2014). 74

Figura 25 - Imagem do LANDSAT 5 do Ribeirão Biritiba-Mirim (SP), com destaque os pontos de amostragens considerados de referência (Fonte: MAPEIA, 2014)......74 Figura 26 - Tubo coletor Kajak-Birkehust modificado, armado para amostragem de água e sedimentos de fundo. Fonte: E.Sorrini ...................................................75

Figura 27 - Tubo coletor Kajak-Birkehust modificado, com água e sedimentos de fundo, retirado de um dos pontos de amostragem. Fonte: E.Sorrini 75 Figura 28 - Tubo coletor Kajak-Birkehust modificado, com água e sedimentos de fundo, retirado de um dos pontos de amostragem. Fonte: J.B.Sígolo. .75

Figura 29 - Procedimento de retirada dos sedimentos de fundo do tubo coletor. Fonte: J.B.Sígolo. .76

Figura 30A e 30B - A - Imagens da Sonda Multiparâmetro Modelo YSI 6820 V2, para determinação de parâmetros "in situ" no Reservatório de Biritiba-Mirim (SP) - B Imagem da mesma sonda, destacando os eletrodos dos parâmetros analisados Fonte: http://www.clean.com.br/

Figura 31 - Determinação de parâmetros "in situ" através da Sonda Multiparâmetro no Reservatório de Biritiba-Mirim (SP) - Fonte: J.B.Sígolo. .76 Figura 32A, 32B, 32C e 32D - Procedimento para digestão e leitura das amostras ambientais para determinação de metais (A - Volume com $50 \mathrm{~mL}$ de amostra, B - 
Acidificação com ácido nítrico, C - Digestão e D - Leitura do elemento químico) Fonte: SABESP .79

Figura 33 - Equipamento ICP OES utilizado para leitura de metais - Fonte: SABESP .79

Figura 34A, 34B, 34C e 34D - Procedimento para digestão e leitura das amostras ambientais para determinação de fósforo total (A-Volume com $5 \mathrm{~mL}$ de amostra, BAcidificação com ácido hidrolizável, C-Adição de $2 \mathrm{~mL}$ de Hidróxido de sódio e DLeitura do elemento químico). Fonte: SABESP. .80 Figura 35 - Equipamento DR5000 utilizado para leitura de fósforo total - Fonte: SABESP 


\section{LISTA DE GRÁFICOS}

Gráfico 1 - Intensidades de chuva mensais e anuais no Reservatório de BiritibaMirim (SP). - dados obtidos de índice pluviométrico da barragem do rio Biritiba-Mirim .

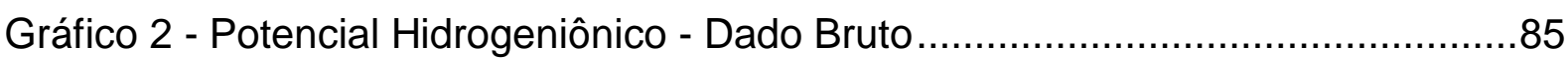

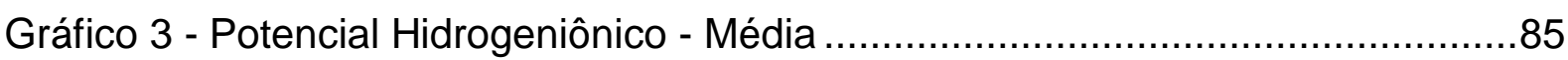

Gráfico 4 - Oxigênio Dissolvido (mg/L) - Dado Bruto..........................................86

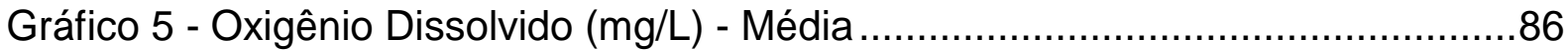

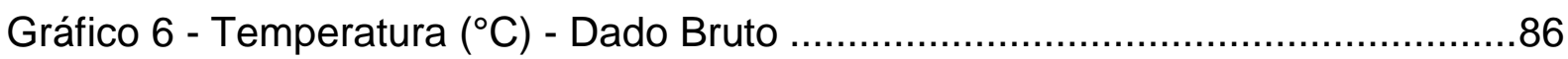

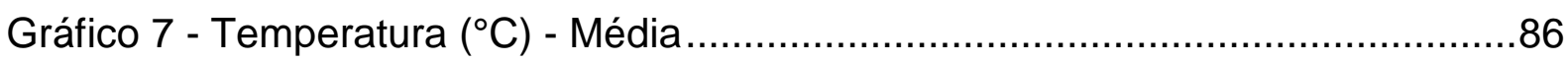

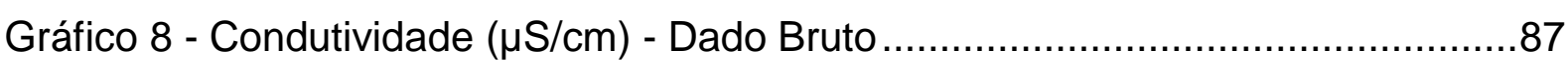

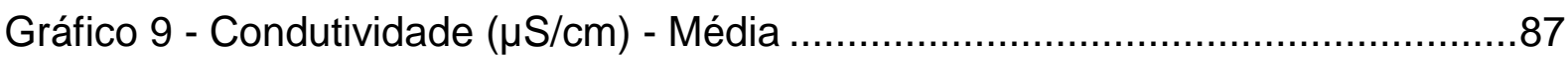

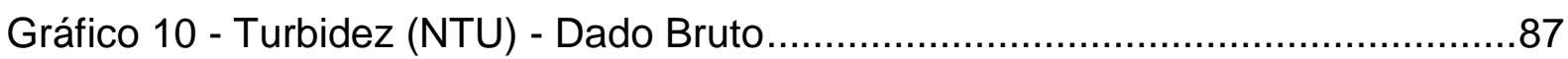

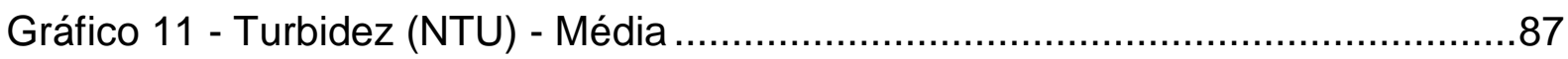

Gráfico 12 - Potencial de Oxirredução $(\mathrm{mV})$ - Dado Bruto ………...........................8

Gráfico 13 - Potencial de Oxirredução $(\mathrm{mV})$ - Média ............................................ 88

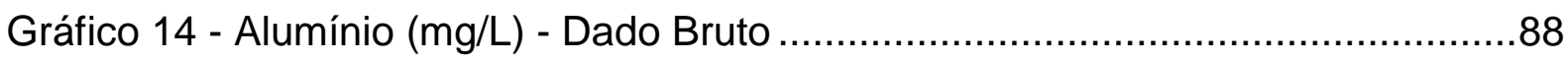

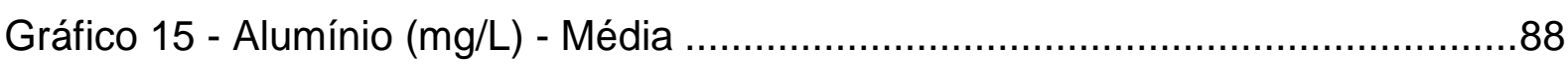

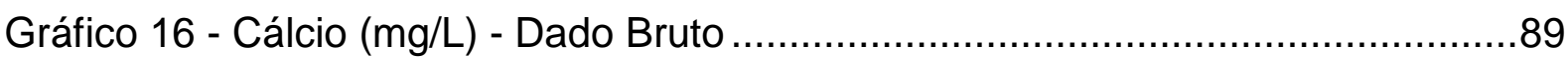

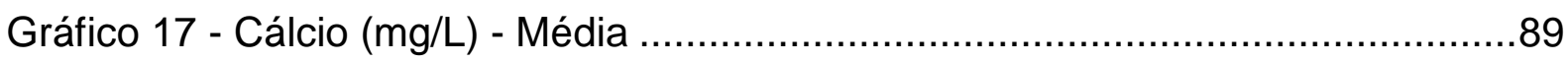

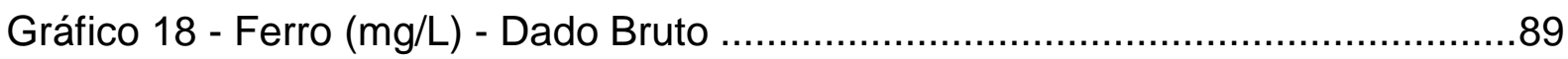

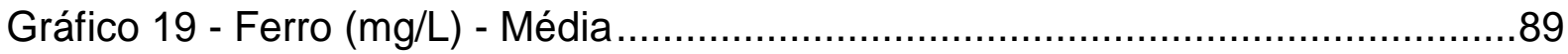

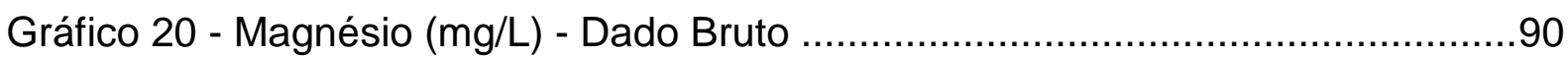

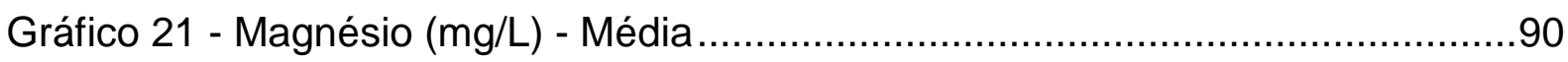

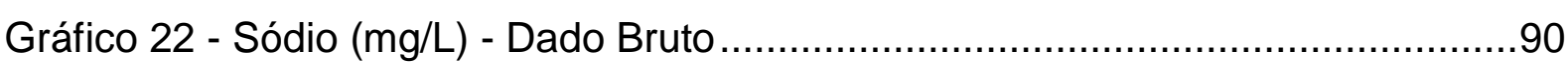

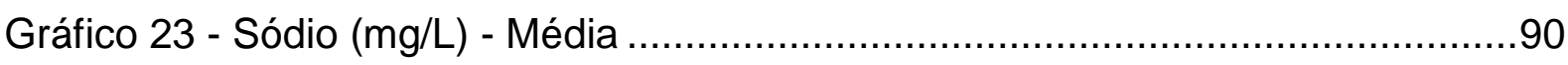

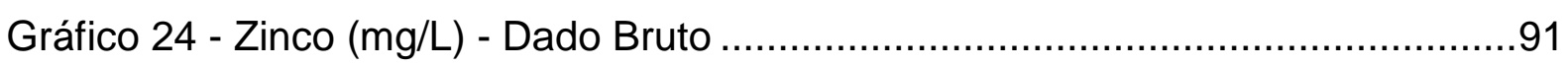

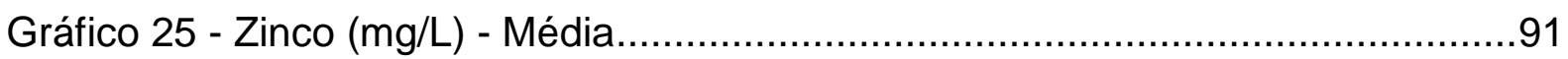

Gráfico 26 - Fósforo (mg/L) - Dado Bruto .........................................................

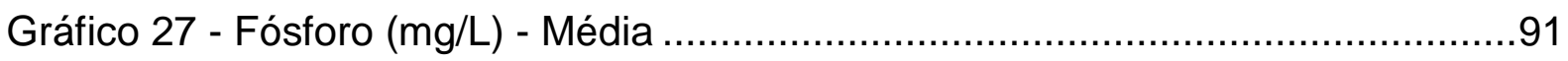

Gráfico 28 - Alumínio (mg/kg)-Dado Bruto ......................................................

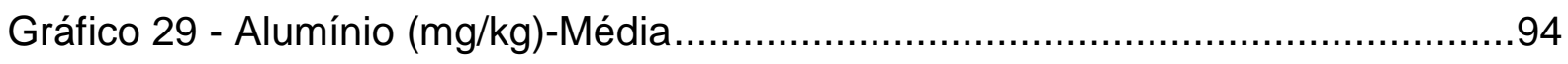

Gráfico 30 - Cálcio (mg/kg) - Dado Bruto .......................................................94 


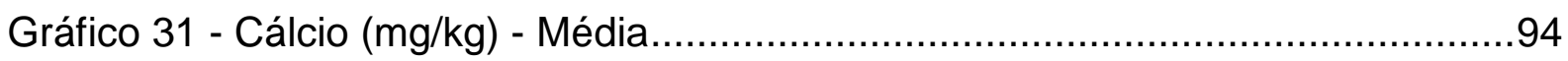

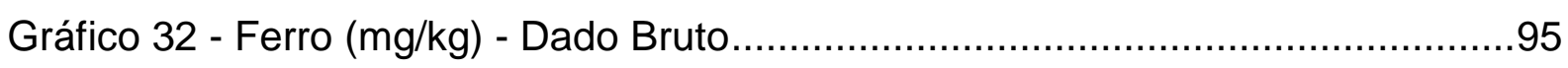

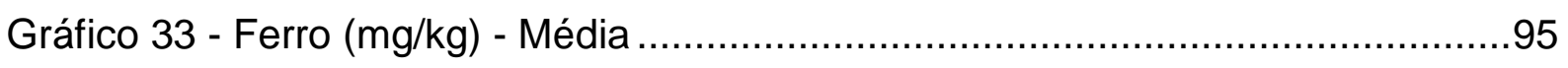

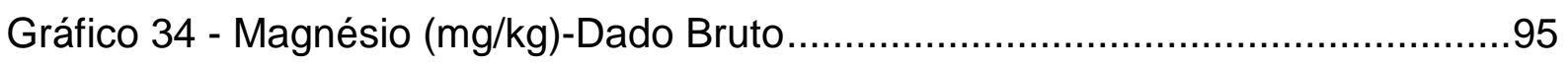

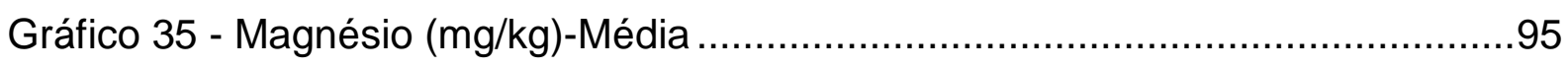

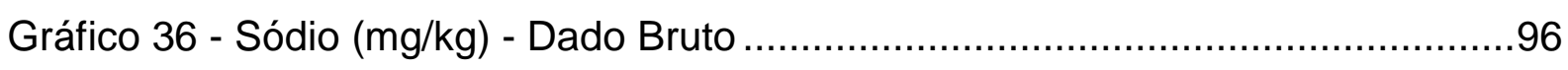

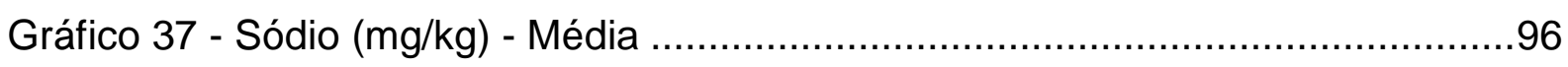

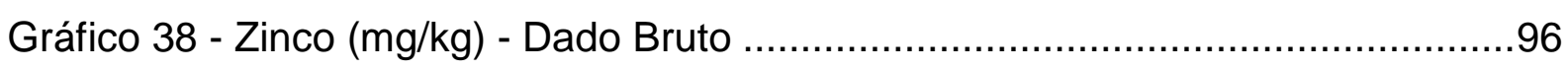

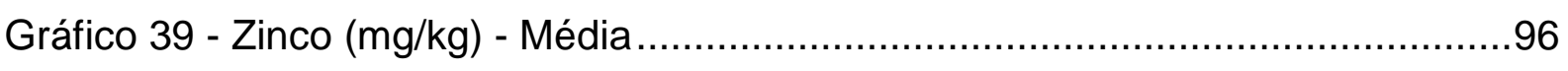

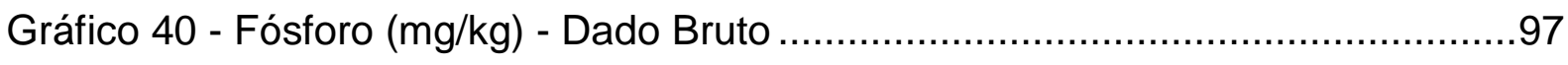

Gráfico 41 - Fósforo (mg/kg) - Média ..........................................................97 


\section{LISTA DE TABELAS}

Tabela 1 - Características gerais do reservatório de Biritiba-Mirim (SP) .50

Tabela 2 - Resultados dos parâmetros físico-químicos determinados "in situ" pela sonda multiparâmetro para o Reservatório de Biritiba-Mirim (SP) na área antrópica agrícola (EDS), sem proteção de mata ciliar.

Tabela 3 - Resultados dos parâmetros físico-químicos determinados "in situ" pela sonda multiparâmetro para o Reservatório de Biritiba-Mirim (SP) na área protegida por mata ciliar (EDL)

Tabela 4 - Resultados dos parâmetros físico-químicos determinados "in situ" pela sonda multiparâmetro na cabeceira do Ribeirão Biritiba-Mirim (SP), valores de referência $(\mathrm{PB})$. .83

Tabela 5 - Resultados dos parâmetros químicos da água analisados em laboratório para o Ribeirão Biritiba-Mirim (SP), ponto considerado de referência (PB1M e PB2J).

Tabela 6 - Resultados dos parâmetros químicos da água analisados em laboratório para o Reservatório de Biritiba-Mirim (SP) na área protegida por mata ciliar (amostras EDL 1,2,3,4,5).

Tabela 7 - Resultados dos parâmetros químicos da água analisados em laboratório para o Reservatório de Biritiba-Mirim (SP) em área antrópica agrícola (amostras EDS 1,2,3,4,5). .85

Tabela 8 - Comparação entre os valores máximos permitidos de elementos químicos em água segundo CONAMA 357/2005 - Classe I. .85 Tabela 9 - Resultados dos elementos químicos encontrados nos sedimentos de fundo analisados em laboratório para o Reservatório de Biritiba-Mirim (SP) na área protegida por mata ciliar (amostras EDL 1,2,3,4,5). .92

Tabela 10 - Resultados dos elementos químicos encontrados nos sedimentos de fundo analisados em laboratório para o Reservatório de Biritiba-Mirim (SP) na área antrópica agrícola (EDS 1,2,3,4,5).

Tabela 11 - Resultados dos elementos químicos encontrados nos sedimentos de fundo analisados em laboratório para o Ribeirão Biritiba-Mirim, no ponto considerado de referência (PBM1 e PB2J). 
Tabela 12 - Comparação entre os Valores Máximos Permitidos de elementos químicos em sedimentos de fundo segundo PEL/TEL (CETESB/2011), Valores Orientadores para Solo CETESB/2014 e Valores para Sedimento CONAMA

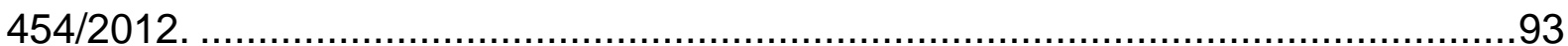




\section{SUMÁRIO}

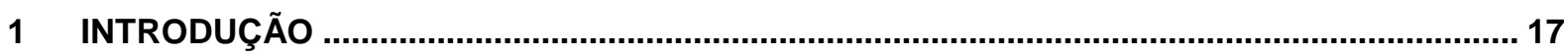

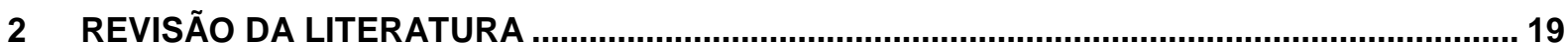

2.1 Uso do solo e sua influência na qualidade e quantidade de água e dos

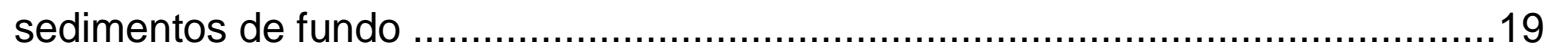

2.2 Importância das Matas Ciliares ..................................................... 33

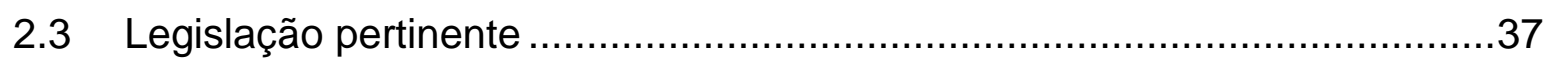

2.4 Bacia Hidrográfica do Alto Tietê.......................................................40

2.5 Caracterizações da Área de Estudo................................................47

2.5.1 O município de Biritiba-Mirim (SP) .................................................47

2.5.2 O Reservatório de Biritiba-Mirim (SP) ..........................................48

2.5.3 As condições climáticas do município de Biritiba-Mirim (SP) ..................50

2.5.4 As características Geológicas da área do Reservatório de Biritiba-Mirim (SP)

2.5.5 As características Hidrogeológicas da área do Reservatório de Biritiba$\operatorname{Mirim}(\mathrm{SP})$ .55

2.5.6 As características Pedológicas da área do Reservatório de Biritiba-Mirim $(\mathrm{SP})$

2.5.7 As características Geomorfológicas da área do Reservatório de Biritiba$\operatorname{Mirim}(\mathrm{SP})$ .58

2.5.8 O uso e Ocupação do Solo da área do Reservatório de Biritiba-Mirim (SP)

2.5.9 A vegetação Natural existente na Bacia Hidrográfica do Alto Tietê .64

2.5.10 A descrição de Floresta Ombrófila Densa na área desta dissertação 64

3 OBJETIVO. 67

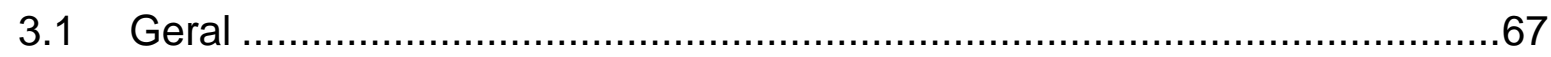

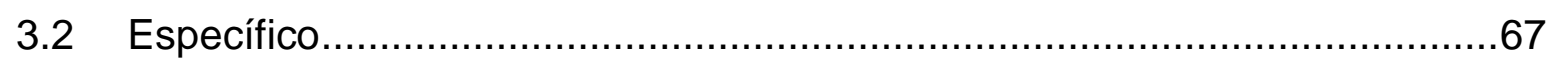

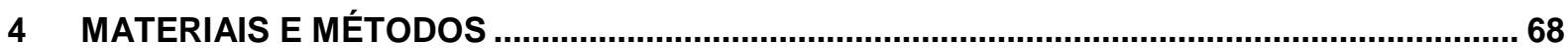

4.1 Trabalhos de Campo................................................................69

4.1.1 Determinação "in situ" de parâmetros físico-químicos da água................77

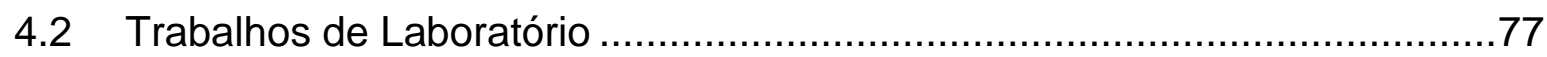

4.2.1 Análise química dos sedimentos de fundo ........................................77 


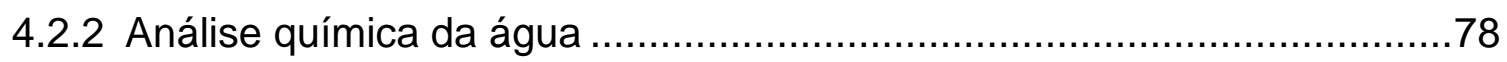

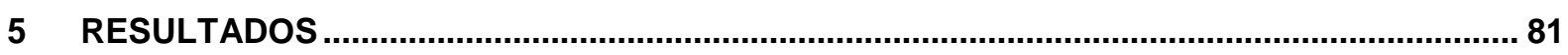

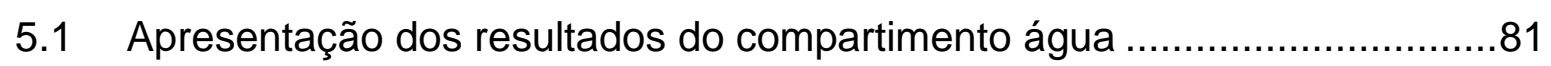

5.1.1 Apresentação gráfica dos parâmetros físico-químicos da água realizados pela Sonda Multiparâmetro nos pontos de amostragem denominados EDS 1,2,3,4,5 (Antrópica); EDL 1,2,3,4,5 (Mata Ciliar); PB1M e PB2J (Ponto Referência), com base nas tabelas: 2, 3 e 4, respectivamente. .85

5.1.2 Apresentação gráfica dos resultados dos elementos químicos encontrados na água realizados em laboratório nos pontos de amostragem PB1M e PB2J (Ponto Referência); EDL 1,2,3,4,5 (Mata Ciliar); EDS 1,2,3,4,5 (Antrópica), com base nas tabelas 5, 6 e 7, respectivamente. .88

5.2 Apresentação dos resultados do compartimento sedimentos de fundo .......92 5.2.1 Apresentação gráfica dos resultados dos elementos químicos nos sedimentos de fundo realizados em laboratório nos pontos de amostragem EDS 1,2,3,4,5 (Antrópica); EDL 1,2,3,4,5 (Mata Ciliar); PB1M e PB2J (Ponto Referência), com base nas tabelas 9,10 e 11, respectivamente......................94

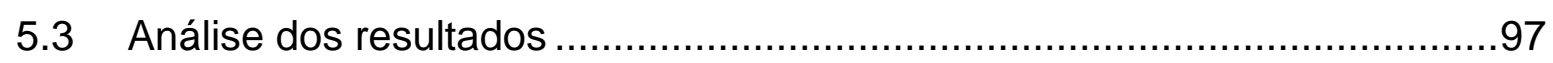

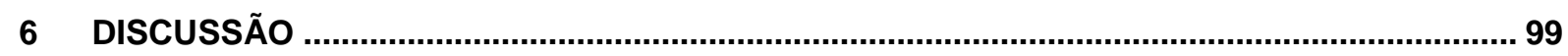

6.1 Discussão referente aos parâmetros físico-químicos encontrados na Água....

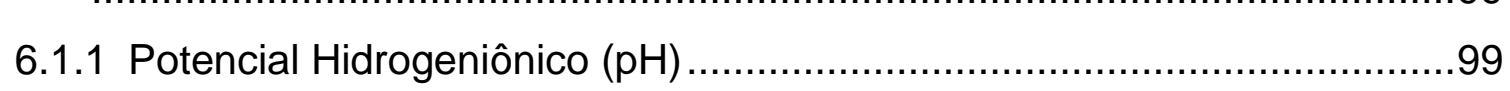

6.1.2 Oxigênio Dissolvido (OD) (mg/L) …………..................................100

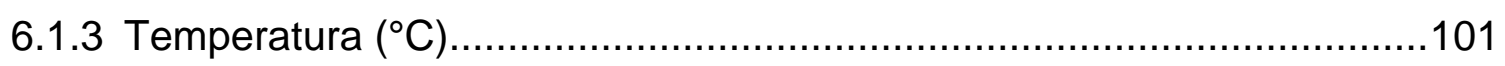

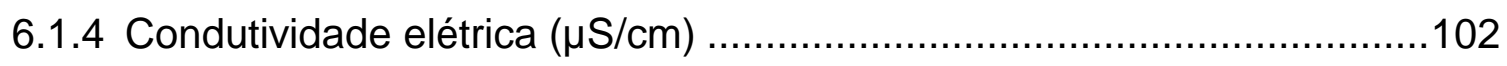

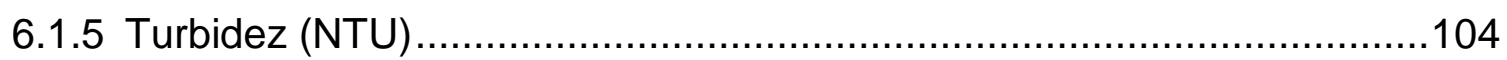

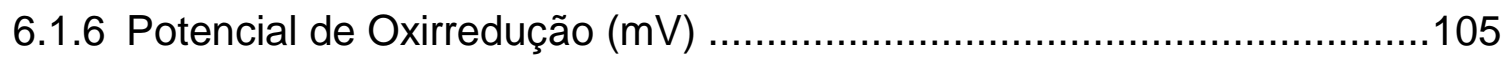

6.2 Discussão referente aos elementos químicos encontrados na Água .........106

6.3 Discussão referente aos elementos químicos encontrados nos sedimentos

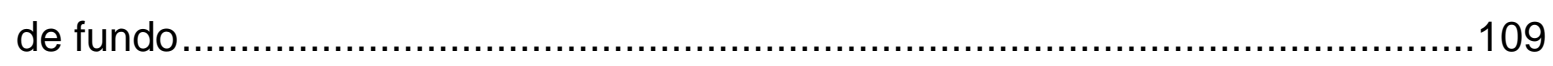

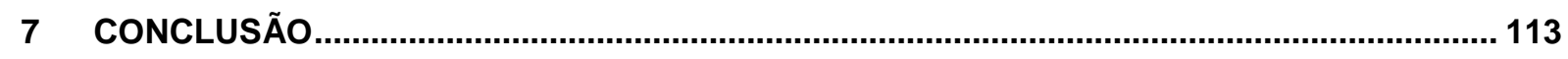

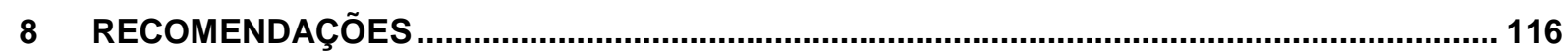

9 REFERÊNCIAS BIBLIOGRÁFICAS.................................................................................. 118 


\section{INTRODUÇÃO}

A água doce representa um dos bens mais preciosos do patrimônio ambiental do ser humano e da Terra. Essencial à continuidade da vida, é também insumo básico para quase todas as atividades humanas e, em consequência, para o desenvolvimento de qualquer sociedade.

Seu valor é inquestionável, inestimável e indispensável para o abastecimento público, servindo de forma importante para diversas atividades industriais, agrícolas, elétrica, de lazer e outros setores da sociedade. Nas últimas décadas, no entanto, com o acelerado desenvolvimento industrial, intensa produtividade agrícola, aglomeração e ocupação desordenada urbana entre outros fatores tais como as alterações climáticas em parte advindas das denominadas mudanças globais, a qualidade e disponibilidade da água para o consumo humano e outras finalidades também importantes, se tornaram motivo de preocupação diante da rápida degradação, consumo e esgotamento que os diversos ecossistemas aquáticos tem demonstrado recentemente.

O Brasil apresenta a maior cobertura florestal do Planeta Terra, favorecendo a existência da maior reserva hídrica em nosso país. Na escola, aprendemos sobre a importância do ciclo hidrológico, mas permanecemos poluindo córregos, rios, lagos e mares. Os processos de precipitações como chuvas, garoas, orvalho, são formas de ocorrência de água na natureza, fazendo parte das trocas do ciclo hidrológico, de ocorrência fundamental para a recarga dos corpos hídricos e aquíferos, importante para o desenvolvimento das espécies vegetais e também para o transporte de partículas de poluição e poeira presentes na atmosfera.

Os processos descontrolados de urbanização ocorrentes em todo globo, com intensas migrações para os conglomerados urbanos, avançando sobre os 
mananciais, com o aumento do número e das atividades industriais, se tornaram um problema para o abastecimento público de água, tendo como consequência a dificuldade de manutenção equilibrada entre demanda desse recurso, sua disponibilidade e sua qualidade.

A construção de reservatórios de água, constituídos por barramento de rios, são de extrema importância para o acumulo de água, desde que haja preocupação em conservar e/ou restaurar suas matas ciliares, para que principalmente, ocorra captação de água de qualidade para consumo humano.

O inadequado planejamento e gestão do uso e ocupação do solo, culminando no avanço populacional e no desenvolvimento de atividades agrícolas no entorno de reservatórios, sem preocupação em manter e/ou restaurar as matas ciliares, vem preocupando e aumentando a atenção quanto à melhoria e conservação da qualidade de suas águas, principalmente para abastecimento público.

A Região Metropolitana de São Paulo (RMSP) é exemplo desse processo de degradação, onde mais de 20 milhões de consumidores estão passando por restrições de consumo de água, devido a criticidade hídrica ocorrida em 2014 e a falta de qualidade da água de alguns mananciais existentes, decorrente do avanço desordenado da população para seu entorno, preocupando os órgãos relacionados a saúde pública.

O reservatório de Biritiba-Mirim (SP), a luz desta dissertação, se apresenta nesse contexto, uma vez que além da pressão urbana do entorno, sem preservação contínua e ideal de sua mata ciliar, a região apresenta aptidão agrícola, onde são empregados agroquímicos, que potencialmente podem estar contaminando o solo e escoando por via superficial para o corpo d'água, alterando a qualidade de sua água, podendo comprometer sua utilização para abastecimento público. 


\section{REVISÃO DA LITERATURA}

\subsection{Uso do solo e sua influência na qualidade e quantidade de água e dos sedimentos de fundo}

Os cursos de água representados pelas bacias hidrográficas continentais estão entre os ecossistemas mais afetados do planeta, com diminuição notável da sua biodiversidade quando comparado com outros ecossistemas terrestres (SAUNDERS et al., 2002).

Nos dias atuais, a crise globalizada da água, é um tema discutido e debatido em diversos países. Pontos como a avaliação quantitativa de disponibilidade hídrica e da qualidade da água disponível para os seus diferentes usos possíveis (abastecimento público, agricultura, pesca, recreação, irrigação e geração de energia), são objeto de descrição importante e alerta, como descreve Lamparelli (2004).

Franco e Druck (1998) já demonstravam o quanto a revolução industrial representou como fator importante na degradação dos ambientes naturais. $O$ somatório constituído pelo desenvolvimento e pelas mudanças tecnológicas da revolução industrial na sociedade moderna, expressa claramente no aumento dos danos causados nos ambientes aquáticos. O lançamento de efluentes industriais e domésticos sem tratamento, a captação irregular da água para uso em seus processos, são alguns dos efeitos degenerativos dos corpos hídricos provocados pelo crescimento industrial e urbano.

Segundo Rebouças, Braga e Tundisi (1999) o Brasil é um grande reservatório de recursos hídricos, representando cerca de $12 \%$ da água doce superficial do planeta, porém essa surpreendente reserva não se encontra geograficamente disponível e ao alcance das grandes concentrações urbanas do país. 
O recrudescimento e diversidade das atividades humanas, somados a crescente ampliação das atividades industriais, a formação de aglomerados urbanos e das mudanças nos padrões de consumo, representa fator de forte pressão sobre o aumento da exploração de recursos diversos, incluindo a água doce disponível, seja de origem superficial, seja subterrânea. Acompanhando essa pressão diversas ações potenciais de alteração do recurso hídrico, tais como, desmatamento, uso inadequado do solo em regiões ripárias, as atividades mineradoras, lançamento de efluentes industriais e domésticos não tratados, construção de reservatórios e barramentos, recursos de pesca com exploração exagerada, atividades agrícolas e pecuárias, introdução de espécies exóticas e invasoras, desvio e retificação de cursos d'água naturais, favorecem a intensificação na degradação dos recursos hídricos de superfície e subsuperfície (GOULART \& CALLISTO, 2003).

Prat e Munné (2000) demonstraram que com a expansão da malha urbana, o uso e ocupação do solo passam a ser lugar comum em forma dominantemente desordenada. Camadas populacionais de baixa renda passam a ocupar essas regiões sob condições de grande pobreza e insuficiente infraestrutura de serviços. Fatores que podem conduzir a deterioração dos mananciais e consequentemente baixos padrões de qualidade da água para o abastecimento público, podendo inclusive até conduzir a escassez deste recurso.

Por outro lado, o solo que circunda bacias hidrográficas e reservatórios, mesmo sendo um recurso essencial para a humanidade, ainda é visto como um recurso renovável, que mesmo sofrendo com fatores de degradação, a reversão é rápida. Pelo contrário, a gênese dos solos é um procedimento muito lento, numa escala geológica de tempo, onde as rochas se degradam e os minerais secundários passam a se formar constituindo assim os solos (RANGEL, 2015). 
Os procedimentos agrícolas, realizados sem os cuidados necessários, como em áreas íngremes e a mecanização inadequada, também podem prejudicar o solo, assim como compactá-lo. Os sistemas de aragem e utilização de maquinário agrícola sem acompanhamento técnico, podem produzir erosão pela concentração de água da chuva em pequenos sulcos. Os processos erosivos beneficiam o detrimento de nutrientes, prejudicando o desenvolvimento das plantas, provocando 0 empobrecimento e a acidificação do solo, sobretudo quando ocorrem queimadas. 0 emprego exagerado de fertilizantes e a prática da monocultura - que extrai do solo sempre os mesmos nutrientes - esgotam o solo. Podendo acarretar a queda da sua produtividade para o cultivo (RANGEL, 2015).

Especificamente, Conceição e Bonotto (2002) destacam serem as atividades agrícolas em que são dispostos de modo inadequado resíduos dessa atividade bem como a aplicação não controlada de fertilizantes fosfatados e defensivos agrícolas representam vetor potencializador da contaminação do solo e consequentemente da água.

De outro lado, a urbanização, através do crescimento populacional, bem como as atividades industriais, pode produzir fontes de contaminação pontuais, o que as difere, por exemplo, das atividades agrícolas: essas produzem fontes poluidoras difusas, que dificultam os estudos e a detecção de compostos poluidores no meio, conforme destacam Prado e Novo (2005).

O emprego de técnicas agrícolas obsoletas gera o agravamento e degradação do meio físico, conciliada às condições arcaicas de uso e ocupação do meio rural $e$ as consequências são: desmatamento no entorno de bacias hidrográficas, erosão do solo, empobrecimento das pastagens nativas, redução das reservas de água do solo e a progressiva queda da sua produtividade natural 
conforme apontado por Braga, Rebouças e Tundisi (2006). As atividades antrópicas agrícolas, são apontadas como as principais e a que mais afetam a qualidade dos recursos hídricos.

Branco $(1986,2002)$ aponta que além da busca por disponibilidade de água, acompanham essa ação, os riscos de contaminação dos mananciais existentes. Dessa forma, não adianta aumentar a oferta de água, sem que haja a devida proteção aos mananciais já existentes, visto que, ações de recuperação e de correção, são mais custosas que as preventivas. De tal forma que as regiões de maior demanda de água potável são também as que menos dispõem de mananciais caracterizados por qualidade compatível com o abastecimento.

O crescimento demográfico observado em todo território brasileiro, tem aumentado as demandas por energia e abastecimento com água potável, principalmente nos centros urbanos. Essas demandas, na medida do possível, vêm sendo providas através da implantação e construção de barragens de acúmulo de água. Essas obras de engenharia, além de propiciar a produção de energia, possibilitam o cultivo de pescado, atendem a irrigação, ao transporte hidroviário, ao controle de enchentes, e tem aproveitamento turístico e recreativo importante (CHAPMAN, 1992; CAVENAGHI et al., 2003; TUNDISI et al., 2006).

Ribeiro et al. (2005) descreve ser a identificação do uso e ocupação dos solos no entorno de lagos e reservatórios e a avaliação das cargas afluentes de nitrogênio e fósforo, ferramentas importantes para o controle da eutrofização e gerenciamento da qualidade da água para usos múltiplos.

Segundo Henry et al. (1998), os reservatórios com tempo de residência (volume/vazão) da água muito baixo assumem características ecológicas próximas 
aos ecossistemas lóticos, enquanto os reservatórios com tempo de residência elevado apresentam características similares a ambientes lênticos.

Em função deste parâmetro e da distribuição advectiva dos sedimentos e nutrientes introduzidos pelos tributários, a extensão de cada uma das três zonas (Figura 1), normalmente encontradas nas represas (zona de influência dos rios próxima à desembocadura dos tributários; zona lacustre - próxima à barragem; e zona intermediária) pode ampliar-se ou reduzir-se muito (COOKE et al., 2005).

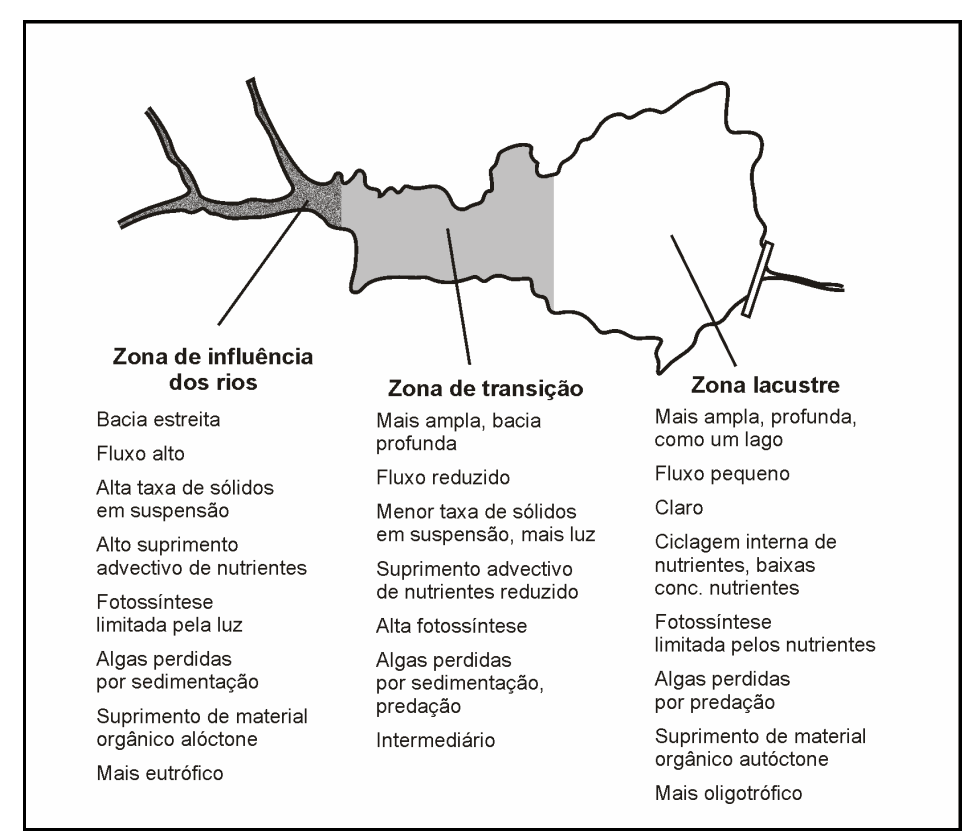

Figura 1 - Esquema de zonação longitudinal de um reservatório (COOKE et al.,2005)

Desse modo as represas funcionam, ao interceptar o fluxo de água de um rio, como "coletores de eventos", proporcionando informações fundamentais sobre as bacias hidrográficas. Constituem importantes centros de convergência das várias atividades desenvolvidas na bacia hidrográfica, inclusive de seus usos e aspectos econômicos e sociais. Além disso, as informações introduzidas no reservatório (aporte de material em suspensão, nutrientes inorgânicos e orgânicos, poluentes, etc.) interferem nos processos de organização das comunidades planctônicas, 
perifíticas e de peixes, bem como na composição química da água e do sedimento (COOKE et al., 2005).

Portanto, a qualidade das águas reflete, em grande parte, as atividades humanas no ar, no solo e na própria água de drenagem (BICUDO et al., 1999).

Os reservatórios são detectores sensíveis dos impactos antropogênicos, pois são ecossistemas artificiais que integram as consequências do uso e ocupação do solo dentro dos limites de sua bacia de drenagem (TUNDISI, 1996).

Para Tundisi (2008) o crescimento populacional, o processo intensivo de urbanização, a alteração das fontes de recursos hídricos e o aumento das fontes de contaminação alteram a qualidade e quantidade da água e, em resposta a essas causas, há interferência na saúde humana e saúde pública.

Conforme descrito por Thomann e Mueller (1987), há duas categorias de fontes de poluição: pontuais, cujos pontos de produção de resíduos e ou de descarga se apresentam em local definido, e muitas vezes com produção constante, como nas estações de tratamento de esgotos domésticos e efluentes das indústrias; e difusas, que não apresentam um ponto de localização, produção e descarga definido. Proporcionando com isso, maior dificuldade de controle e monitoramento.

Segundo Prado (2004), os sistemas aquáticos como os reservatórios sofrem alterações em sua dinâmica, seja pela própria construção do mesmo e, também, pela intervenção da atividade humana que impacta diretamente os recursos hídricos, agravando o problema da degradação da água. A construção do reservatório permite o aumento da capacidade de armazenamento de materiais orgânicos e inorgânicos provenientes da bacia de captação, sejam originários de fontes pontuais ou difusas. 
Calcula-se que vivam nas Áreas de Proteção e Recuperação dos Mananciais (APRMs) na RMSP cerca de 2 milhões de habitantes as quais ocupam uma área próxima a $4.500 \mathrm{Km}^{2}$, representando nesse caso mais ou menos $54 \%$ dos $8.051 \mathrm{~km}^{2}$ da área total dessa região. Invasões frequentes nessas áreas é fruto do abandono das regiões centrais da cidade e expansão dos limites periféricos. Nesse caso também, podendo ser produto de intensa especulação imobiliária; da concepção de indústrias e serviços próximos a estes mananciais, além da ausência de programas habitacionais adequadamente planejados e que não incorporem evidencias eleitorais (ISA, 2006; SSRH, 2015).

Reduzindo-se a região estudada, objeto desta dissertação, que se encontra dentro da RMSP identifica-se ser essa região forte absorvedora de água, seja por seu pujante parque industrial distribuído pela RMSP ou por intenso parque agrícola, ambos se espraiam pelo estado inteiro. Mais especificamente a RMSP possui área de $8.051 \mathrm{~km}^{2}$ e população, que em 2014, já atinge a casa dos 20 milhões de habitantes quase $10 \%$ da população do Brasil. Izazola e Carmo (2004) destacam neste cenário, que a maior parte dos municípios da RMSP estão sediados geograficamente dentro da Bacia Hidrográfica do Alto Tietê (BHAT).

A BHAT, integra 34 dos 39 municípios da RMSP, é responsável pela drenagem de 70,17\% dessa região. Apresenta superfície próxima de 6.000 km². Como observação importante deve ser mencionado que somente $5 \%$ da área da bacia se apresenta fora da RMSP (FUSP, 2001; CBH-AT, 2001).

Waldman (2005) cita que essa bacia (Alto Tietê) representa um dos mais importantes sistemas de provimento de água para a metrópole paulista, e segundo Whately e Diniz (2009), a bacia hidrográfica do alto Tietê é também considerada uma das bacias que apresenta menor disponibilidade hídrica per capita do Brasil. 
Lomba (2010) demonstrou que a RMSP, apresenta um sistema integrado de abastecimento de água potável, que compreende sistemas produtores, que utilizam fundamentalmente, mananciais de superfície, os quais embora em colapso (2014/2015) representam as fontes mais importantes de abastecimento da Grande São Paulo.

A luz desta dissertação, no entendimento desse autor, a expansão urbana concomitante com os processos industriais, agricultura e pecuária são instrumentos de pressão constantes ao meio ambiente, podendo levar à ruptura do equilíbrio, levando a consequências imprevisíveis, a água, solo, ar e ao causador homem.

E as ações de monitoramento, através de diagnóstico ambiental nos sistemas hídricos (água e sedimentos), são de extrema importância como indicador e consequentemente promotor de ações de gestão para melhoria da qualidade ambiental do meio.

Segundo Hart (1982), os sedimentos são compostos por uma mistura complexa de fases sólidas das quais podem fazer parte a argila, matéria orgânica, carbonatos, sulfetos, sílica, óxidos metálicos tais como $\mathrm{FeOOH}, \mathrm{MnO}_{2}, \mathrm{Al}_{2} \mathrm{O}_{3}$, minerais e bactérias.

Mudrock e Machnigh (1991), descrevem sedimento de fundo, ou todo material não consolidado, como sendo formado por partículas de diversos tamanhos, formas e composição química, transportadas por ar, água, ou gelo e espalhadas ao longo dos vales do sistema de drenagem e encaminhado a partir dos processos contínuos e constantes de intemperismo e erosão.

Segundo Calvert (1976), sedimentos são frações de rocha e minerais provindos da terra pelo processo de intemperismo e encaminhados aos lagos e oceanos através dos rios, gelo ou vento. Os sedimentos também podem ser 
considerados matéria orgânica, precipitados de origem inorgânica que são desenvolvidos na água, mas que também podem ser constituídos após deposição no sedimento.

Desse modo, segundo Bevilacqua (1996), os sedimentos por atuarem como fontes carreadoras de contaminantes, principalmente metálicos que permanecem insolúveis mesmo quando em água, e como não são permanentemente fixados, podem ser ressolubilizados para a água por instabilidade nas condições ambientais, sendo potenciais fontes de poluição. Portanto, representam uma importante fonte de informações ao se realizar um diagnóstico ambiental de águas continentais, pois possuem a capacidade de mensurar a qualidade desse ambiente, podendo ser utilizado como instrumento de suporte a decisão em determinados processos investigativos.

Bevilacqua (1996), também descreve que através dos ciclos biogeoquímicos que realizam o controle, o aumento e a redistribuição das espécies de contaminantes químicos despejados nos rios, lagos e represas, permanecem por muitos anos nesses ambientes. Nesse processo biogeoquímico de interação do metal com o sedimento, a dimensão da partícula de sedimento é a variável mais importante.

Segundo Forstner (1977) e Krumgalz et al. (1992), os elementos traços de origem antropogênica e natural com partículas com tamanho de grão $<63 \mu \mathrm{m}$, estão especialmente concentrados nas frações de silte e argila do sedimento.

Conforme descrito por Krumgalz (1989), devido à grande área com capacidade de adsorção, quanto menor o grão, maior é a concentração de contaminantes. Mas realizando novos experimentos, o mesmo autor, verificou que também ocorre enriquecimento de matéria orgânica e metal em fragmentos que 
apresentam partícula com tamanho superior a $250 \mu \mathrm{m}$, podendo ser a consequência da formação de grandes agregados de fragmentos de sedimentos menores, aumentados pelos contaminantes.

Segundo Philips ${ }^{1}$ (1977, apud JESUS et al., 2004), o processo de liberação antrópica de metais pesados nos diferentes ambientes naturais vem causando enormes impactos ao meio ambiente. Os ambientes aquáticos, por estarem em regiões estratégicas integradas com a população rural e urbana, estão sofrendo consequências desastrosas.

Salomons e Förstner² (1984, apud JESUS et al., 2004) relatam que a utilização da água, de materiais particulados, de sedimentos e organismos aquáticos são importantes nas avaliações ambientais, devido às facilidades de amostragem, estocagem, tratamento dessas amostras e às grandes concentrações encontradas no meio.

Para CETESB (1999), a poluição das águas tem consequência direta com a poluição dos sedimentos e tem origem em diferentes fontes, como: efluentes domésticos e industriais, fontes difusas e carga urbana e agrícola. Núñez et al. (2006) relatam que o uso de agroquímicos para aumentar o suprimento de nutrientes e a correção do pH do solo podem causar degradação química do solo devido ao acúmulo em níveis indesejáveis. Estas substâncias, por muitas vezes não serem purificadas, geralmente contém diversas impurezas como, por exemplo, metais pesados.

1 PHILLIPS, D. J. H.; The use of biological indicator organisms to monitor trace metal pollution in marine and estuarine environments - a review, Environmental Pollution, v.13, pp. 281-317, 1977.

2 SALOMONS, W.; FÖRSTNER, U.; Metals in Hydrocycle, Berlin: Springer-Verlag, 1984. 352p. 
De acordo com Jesus et al. (2004), os sedimentos são considerados bons indicadores de espécies poluentes, uma vez que apresentam alta capacidade de sorção, na qual as concentrações de poluentes tornam as ordens de grandeza maiores do que as águas correspondentes. Eles ainda possibilitam o conhecimento das principais fontes de poluição dentro de um sistema aquático. Para Pereira et al. ${ }^{3}$ (1998, apud HORTELLANI et al., 2008) os sedimentos têm esta utilização por possuírem grande capacidade de incorporação e acumulação de elementos contaminantes. Ainda de acordo com Pereira et al. (1998, apud HORTELLANI et al., 2008), por serem carreados devido ao processo de erosão do solo e através de cursos d'água, torna-se possível rastrear as fontes de contaminação por meio de coletas e análise destes sedimentos em diferentes pontos.

Os diversos processos bióticos e abióticos podem remobilizar as espécies poluentes passando a constituir fonte de poluição secundária, capaz de afetar a qualidade da água. Deste modo, vimos que a contaminação de sedimentos é um importante problema ambiental em todo mundo (JESUS et al., 2004).

Hortellani et al. (2008) mencionam que as condições abióticas do meio aquático $(\mathrm{pH}$, salinidade, entre outras) interferem na liberação de poluentes incorporados ao sedimento. Com isso, as mudanças das condições ambientais podem transformar os sedimentos em fontes de contaminação da água e dos organismos bentônicos. Para Núñez et al. (2006) os metais pesados presentes no solo erodido quando atingem cursos d'água contaminam o corpo d'água pois podem ser liberados quando há mudanças físico - químicas do meio e tornam-se perigosos em condições redutoras. Entretanto, a solubilidade dos metais pesados quando

3 PEREIRA, M. E.; DUARTE, A. C.; MILlWARD, G. E.; ABREU, S. N.; VALE, C. An estimation of industrial mercury stored in sediments of a confined area of the Lagoon of Aveiro (Portugal). Water Science and Technology, v. 37, n. 6, 125-130, 1998. 
depositados na superfície do solo depende da facilidade de remobilização dos mesmos.

As alterações nas características físicas e químicas do ambiente podem influenciar diretamente a qualidade da água e tornar os contaminantes e nutrientes acumulados nos sedimentos disponíveis para a coluna d'água (BEVILACQUA, 1996).

Paiva et al. (2014) descreve que à influência do relevo, do solo, da precipitação e uso da terra devem ser investigadas, sobretudo por meio dos fenômenos erosivos nas bacias hidrográficas, que causam o transporte de sedimentos para o corpo hídrico.

Esteves (1998), descreve que os lagos e reservatórios, por representarem bacia de sedimentação, com características específicas de ambientes deposicionais, podem ser considerados fontes potenciais de elementos químicos tóxicos, especialmente alguns metais, que podem alcançar elevados níveis de contaminação. Amazarray (1992), afirma também que no interior desses ambientes lacustres os metais potencialmente tóxicos oriundos do meio litogênico e antropogênico se apresentam distintos nos diversos compartimentos, mas sua existência reflete diretamente na interação entre os sedimentos, as macrófitas, e a hidrodinâmica da coluna d'água.

Esses elementos metálicos que apresentam origem natural são transportados e depositados nos sedimentos de fundo de lagos, rios e oceanos e advém especialmente de elementos traços do intemperismo de rochas, e da erosão das planícies aluvionares e dos solos ricos desses metais (FÖRSTNER e WITTMAN, 1981; MOORE e RAMAMOORTY, 1984; STUMM e MORGAN, 1996). 
Carvalho e Tavares (1992) descrevem que muitos desses elementos e de outros não frequentes naturalmente e com viés de origem antrópica, como os fertilizantes, pesticidas, águas de irrigação contaminada, queima de biomassa na zona rural, combustão de carvão e óleo, emissões veiculares, deposição de resíduos urbanos e industriais e, principalmente curtumes, mineração, fundição e refinamento de metais, são as principais fontes de metais no meio ambiente.

Casagrande e Salvador ${ }^{4}$ (2007, apud PEREIRA, 2008) descrevem que os três principais nutrientes exigidos pelas culturas são o nitrogênio $(N)$, potássio $\left(K_{2} \mathrm{O}\right)$ e fósforo $\left(\mathrm{P}_{2} \mathrm{O}_{5}\right)$, sendo que o uso intensivo destes compostos nas culturas favorece o aparecimento dos mesmos nas águas superficiais e subterrâneas.

Para Alloway et al. (1997) as ações realizadas nas culturas agrícolas, são caracterizadas como sendo as mais importantes fontes não pontuais, ou seja, difusas, de contaminação por elementos químicos metálicos. Sendo os mais frequentes listados abaixo:

Presentes nos fertilizantes: $\mathrm{Cd}, \mathrm{Cr}$, Mo, $\mathrm{Pb}, \mathrm{U}, \mathrm{V}$ e Zn.

Presentes nos defensivos agrícolas: $\mathrm{As}, \mathrm{Cu}, \mathrm{Hg}, \mathrm{Mn}, \mathrm{Pb}$ e $\mathrm{Zn}$.

Presentes nos excrementos de produção de porcos e aves: As, Cu e Zn.

A interação entre o solo e os defensivos agrícolas é caracterizada e constituída por todos os elementos presentes no solo, que influenciam o processo de adsorção das substâncias, e onde também a movimentação e biodisponibilidade dos elementos contaminantes no solo apresenta relação intrínseca com o potencial de lixiviação, sorção, absorção e degradação do contaminante pela vegetação (DORES; DE-LAMONICA, 1999).

${ }^{4}$ CASAGRANDE, L.A.R.; SALVADOR, N.N. Uso de Insumos Agrícolas e Ocorrência de Nitrato nas Águas Subterrâneas. In: CONGRESSO DE PÓS-GRADUAÇÃO, 4., 2007, São Carlos, Anais de Eventos da UFSCar, v. 3, p. 1793. 2007. 
Os processos químicos e microbiológicos também podem degradar os agrotóxicos no solo, tendo como subproduto resultante dióxido de carbono e amônia (RIBEIRO, et al., 2007).

Segundo Barona e Romero5 (1996, apud FADIGAS et al., 2002), as concentrações de elementos metálicos nos sedimentos, são dependentes de fatores como o teor e a composição da argila, da matéria orgânica e as condições físicoquímicas do meio.

Segundo Lemes (2001), um dos maiores fatores de ocorrência de perigo de contaminações por elementos metálicos do meio, é quando esses se apresentam unidos aos sedimentos, pois o transporte dos contaminantes é facilitado, assim são encaminhados para outros locais, e dependendo do nível de concentração do elemento metálico, em longo prazo, pode se tornar em uma fonte de liberação desses elementos.

Segundo o Ministério do Meio Ambiente - MMA (2015), o Brasil é o maior consumidor de produtos agrotóxicos no mundo, e pela importância, tanto em relação à sua toxicidade quanto à escala de uso no Brasil, os agrotóxicos possuem grande cobertura e normas legais no país. O referencial legal mais importante é a Lei no $7802 / 89$.

A luz desta dissertação, este autor entende, que o Brasil sendo o maior consumidor de agrotóxicos do mundo, indiretamente também terá seus solos e suas águas mais contaminadas do mundo. As ações de controle e preservação devem ser imediatas.

5 BARONA, A.; ROMERO, F. Distribution of metals in soils and relationships among fractions by principal component analysis. Soil Technology, Cremlingen, v.8, p.303-319, 1996. 
O agrotóxico no meio ambiente apresenta um comportamento muito complexo. Independente da maneira de aplicação, quando utilizado, apresenta uma grande possibilidade de atingir os compartimentos solo e água, devido, principalmente aos fatores ventos e chuvas, que causam a lavagem das folhas tratadas, a lixiviação e a erosão. Concomitante a isso, não importando o caminho do agrotóxico no meio ambiente, o ser humano é seu potencial receptor (MMA, 2015).

Segundo o entendimento deste autor, o avanço desordenado nos processos de uso e ocupação do solo no meio urbano e rural, principalmente em áreas protegidas, concomitante com o descaso, falta de planejamento, falta de orientação e recursos, corroboram para o avanço dos processos de degradação do meio, e no caso rural, dificultando muito o uso sustentável das terras. Por essa razão, de modo objetivo, e com utilização de ferramentas simples, como a implantação de curvas de nível e manutenção e ou restauração das matas ciliares nas margens dos corpos hídricos e topos de morros, são essenciais. São ações para evitar os processos erosivos, que além de provocarem assoreamento e carreamento, também apresentam como resultado a deposição nos leitos dos corpos hídricos de substâncias tóxicas como agrotóxicos e fertilizantes.

\subsection{Importância das Matas Ciliares}

A legislação florestal brasileira desde 1965 , com a Lei $4.771 / 1965$, que foi revogada pela Lei 12.651/2012, exige das propriedades rurais, a conservação de no mínimo $20 \%$ de sua área preservada com vegetação nativa - são as chamadas reservas legais. Além das reservas legais, são áreas consideradas de preservação permanente (APP): ao longo de rios, das nascentes, dos corpos d'água, e das encostas com mais de $45^{\circ}$ de inclinação. 
As APP foram determinadas pelo Código Florestal brasileiro como áreas com ou sem vegetação, destinadas à proteção do meio ambiente e manutenção da vida em toda sua diversidade (BRASIL, 2012).

Entretanto, a luz desta dissertação, este autor observa que são muito raras as situações em que essa lei é cumprida. Isso devido principalmente a inexistência de uma apropriada fiscalização de uso dos solos. Concomitante a esse fator, os setores de empreendimentos, especialmente os locados nas regiões mais desenvolvidas, não apresentam tradição nas ações de preservação dos ambientes florestais, e via de regra tratam as áreas preservadas por florestas como sendo um impedimento aos processos de desenvolvimento. Muitos não concordam em investir dinheiro em restauração florestal, principalmente se não for por meio de ação judicial e se tiver como único objetivo a conservação dos ambientes florestais.

A importância das matas ciliares para a proteção das nascentes, rios e lagos, é análoga a proteção dos cílios para os olhos. Na figura 2, em seu lado esquerdo, observa-se um rio saudável, protegido por mata ciliar. Em seu lado direito, observase os impactos causados pela inexistência dessa vegetação. A ausência das matas ciliares, provoca seca nas nascentes, solapamento nas margens dos riachos e rios, redução no processo de infiltração no solo, aumento do escoamento superficial, causando a redução das reservas de água do solo e do lençol freático. Apresentando como consequências principais, a poluição difusa que chega com muita facilidade aos mananciais, prejudica consideravelmente a vida aquática e potencializa a ocupação desordenada nas margens dos rios e reservatórios (SMA, 2015). 


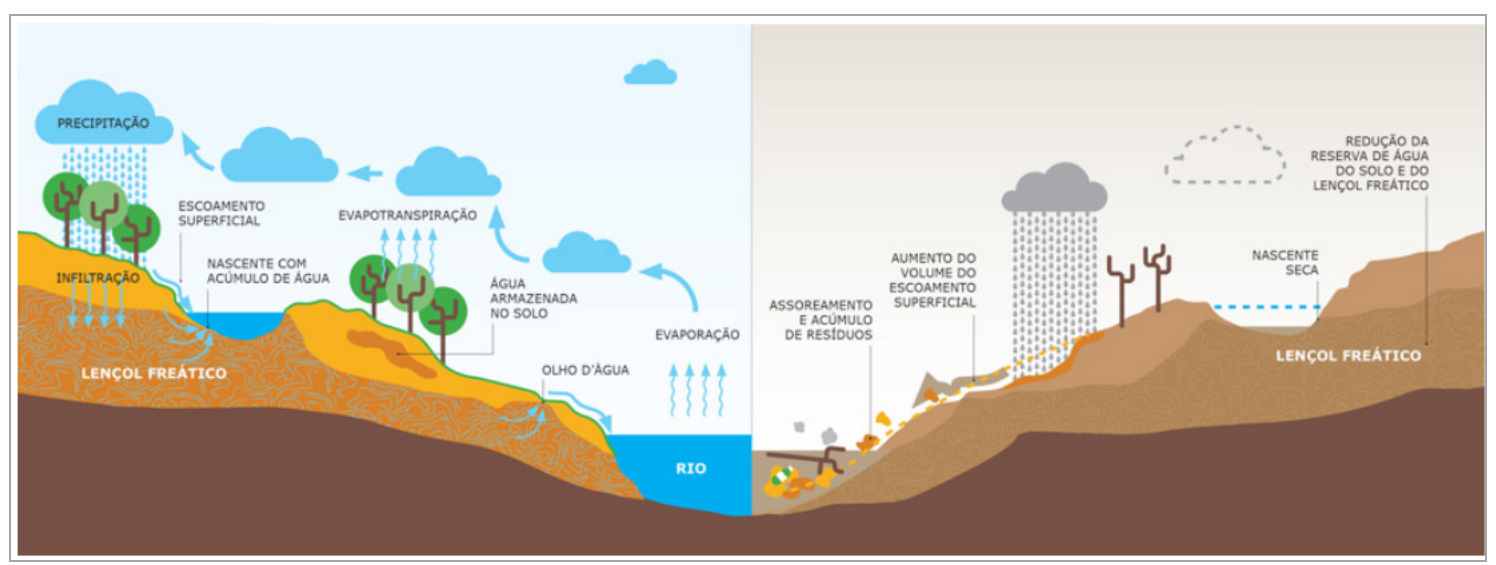

Figura 2 - A importância das matas ciliares (Fonte: SMA, 2015)

Martins (2007) entende por vegetação ciliar ou ripária, aquela que margeia as nascentes e os cursos de água. Cita também outras denominações habitualmente usadas em diferentes regiões do Brasil, como: floresta ripária, florestas ribeirinhas, matas de galeria, floresta ripícola, e floresta beiradeira. Uma definição mais técnica para esta vegetação, é denominada, mata ciliar aquela vegetação remanescente nas margens dos cursos de água em uma região originalmente ocupada por mata.

As matas ciliares, independentemente de sua origem ou denominação, é toda vegetação que margeia os cursos d'água e as nascentes, e sua preservação é essencial para a biodiversidade e também de extrema importância para a conservação dos recursos hídricos (MARTINS, 2007).

As matas ciliares também são essenciais para conservação da biodiversidade, servindo também como habitat e pelo motivo de muitas espécies de animais e microrganismos sobreviverem e dependerem diretamente dela e de sua conservação (CHAVES, 2009).

Krupek e Felski (2006), descrevem que as matas ciliares exterminadas modificam os índices de luminosidade incidentes no corpo hídrico, interferindo na temperatura e na composição química da água, comprometendo diretamente as diversas espécies encontradas naquele ambiente. Por essa razão, os autores 
destacam que as matas ciliares são importantes não só para a biodiversidade terrestre, como também para a biodiversidade das espécies que vivem nos ambientes aquáticos.

Lima e Zakia (2000) atribuem também à mata ciliar ou floresta ripária, a função de corredor ecológico de circulação da fauna, e também não menos importante, colaborando para o fluxo gênico "in situ" e "ex situ", através dos processos ecológicos de dispersão de plantas e sementes.

Santos et al. (2008), relacionam a existência da mata ciliar protegida com a redução do aporte de contaminantes por poluição difusa no meio rural, apontada pela diminuição do fenômeno de sedimentação e dos processos erosivos, que são a causa de uma séria ameaça aos reservatórios de água existentes no Brasil. A sedimentação e os processos erosivos podem provocar também, o aumento de doenças de veiculação hídrica, principalmente aquelas causadas por microrganismos patogênicos entre eles bactérias e vírus, que são carreados e adsorvidos aos sedimentos e consequentemente depositados no corpo hídrico.

Segundo Rodrigues e Filho (2004), a vegetação ripária ou matas ciliares apresentam importante performance nas funções ecológicas e hidrológicas em uma bacia hidrográfica, pois são compostas por formações vegetais hidrófilas encontradas ao longo dos cursos d'água, em locais de solos úmidos ou até mesmo encharcados, sujeitos a inundações transitórias.

A luz desta dissertação, este autor ratifica as afirmações dos autores acima descritas, onde as matas ciliares com suas inúmeras denominações, são de extrema importância para qualidade ambiental dos ecossistemas e para vida humana.

Ferreira, Rocha e Figueiredo (2015), atentam que a utilização de indicadores físico-químicos é de extrema importância para um bom entendimento das alterações 
ocorridas na qualidade das águas dos corpos hídricos. Onde pode-se comparar os resultados encontrados, com as possíveis interferências antrópicas ocorrentes na bacia hidrográfica. Alerta também para uma maior conscientização e equilíbrio entre o ser humano e o recurso hídrico, não se distanciando da urgente necessidade de preservação e manutenção dos limites das matas ciliares ou ripárias.

Considera também que todos os fatores que interferem diretamente sobre a qualidade e o volume de água disponível no Brasil, destaca-se principalmente a degradação ou destruição total da vegetação ciliar do entorno das nascentes e dos copos hídricos. Apesar da necessidade de urgência nas ações de reversão dessa situação, obstáculos de ordens, culturais, econômicas e sociais impedem 0 entendimento da conscientização da coletividade.

A luz desta dissertação, este autor, entende que nas duas últimas décadas a preocupação com a conservação e restauração ecológicas desses ecossistemas tem aumentado muito, motivados principalmente por um maior nível de conscientização da sociedade, maior rigor na aplicação e cumprimento da legislação ambiental, além dos avanços na pesquisa voltada ao desenvolvimento de sistemas e modelos de manutenção, restauração, recuperação de matas ciliares e áreas degradadas.

\subsection{Legislação pertinente}

No que se refere a qualidade da água dos reservatórios, a resolução CONAMA no 357/2005 - Dispõe sobre a classificação dos corpos de água e diretrizes ambientais para o seu enquadramento, bem como estabelece as condições e padrões de lançamento de efluentes, e dá outras providências. Em seu inciso II, art. 4, nas quais as águas doces são classificadas em: 
Art. 4. As águas doces são classificadas em:

II - Classe 1: águas que podem ser destinadas:

a) Ao abastecimento para consumo humano, após tratamento simplificado;

b) À proteção das comunidades aquáticas;

c) À recreação de contato primário, tais como natação, esqui aquático e mergulho, conforme Resolução CONAMA no 274, de 2000;

d) À irrigação de hortaliças que são consumidas cruas e de frutas que se desenvolvam rentes ao solo e que sejam ingeridas cruas sem remoção de película;

e) À proteção das comunidades aquáticas em Terras Indígenas.

Alusivo a qualidade dos sedimentos de fundo, a resolução CONAMA ํo 454/2012 - Estabelece as diretrizes gerais e os procedimentos referenciais para o gerenciamento do material a ser dragado em águas sob jurisdição nacional. Em seu art. 10:

Art. 10. Após a caracterização química do material a ser dragado, procederse-á sua classificação química, para fins de avaliar as condições de sua disposição observando os seguintes critérios:

II - para avaliação das alternativas de disposição em águas sob jurisdição nacional, os resultados da caracterização química devem ser comparados com os valores orientadores previstos na Tabela III do Anexo desta Resolução e classificados em dois níveis:

a. Nível 1 - limiar abaixo do qual há menor probabilidade de efeitos adversos à biota;

b. Nível 2 - limiar acima do qual há maior probabilidade de efeitos adversos à biota.

A Decisão de Diretoria da CETESB 045/2014/E/C/I, de 20-02-2014 - Dispõe sobre a aprovação dos Valores Orientadores para Solos e Águas Subterrâneas no Estado de São Paulo - 2014. São concentrações de substâncias químicas derivadas por meio de critérios numéricos e dados existentes na literatura científica internacional, para subsidiar ações de prevenção e controle da poluição, visando à proteção da qualidade dos solos e das águas subterrâneas e o gerenciamento de áreas contaminadas. O Valor de Referência de Qualidade - VRQ é a concentração de determinada substância no solo ou na água subterrânea, que define um solo como limpo ou a qualidade natural da água subterrânea.

Os critérios para classificação de sedimento também são baseados na probabilidade de ocorrência de efeito deletério sobre a biota, onde o menor limite - 
TEL (Threshold Effect Level) - representa a concentração abaixo da qual raramente são esperados efeitos adversos para os organismos. E o maior limite - PEL (Probable Effect Level) representa a concentração acima da qual é frequentemente esperado o citado efeito adverso para os organismos.

$\mathrm{Na}$ faixa entre TEL e PEL situam-se os valores onde ocasionalmente esperam-se tais efeitos. A adoção desses valores teve caráter meramente orientador na busca de evidências da presença de contaminantes em concentrações capazes de causar efeitos deletérios, sobretudo com relação à toxicidade para a biota. (CETESB, 2011).

No que se refere a proteção das matas ciliares, a Lei Federal ํㅜ 12.651, de 25 de maio de 2012, que dispõe sobre a proteção da vegetação nativa, em seu inciso II, art. 3., entende-se por área de Preservação Permanente - APP:

Art. 3. Para os efeitos desta Lei, entende-se por:

II - Área de Preservação Permanente - APP: área protegida, coberta ou não por vegetação nativa, com a função ambiental de preservar os recursos hídricos, a paisagem, a estabilidade geológica e a biodiversidade, facilitar 0 fluxo gênico de fauna e flora, proteger o solo e assegurar o bem-estar das populações humanas.

E em seu inciso III, Art. 4., considera-se Área de Preservação Permanente, em zonas rurais ou urbanas, para os efeitos desta Lei:

Art. 4. Considera-se Área de Preservação Permanente, em zonas rurais ou urbanas, para os efeitos desta Lei:

III - as áreas no entorno dos reservatórios d'água artificiais, decorrentes de barramento ou represamento de cursos d'água naturais, na faixa definida na licença ambiental do empreendimento.

Alusivo a avaliação da condição de preservação da área de estudo desta dissertação, ou seja, a mata ciliar protegida, a Resolução CONAMA no 10/1993, conforme incisos I-IX do art. 1., que estabelece os seguintes parâmetros básicos para análise dos estágios de sucessão da Mata Atlântica: 
Art. 1. Para efeito desta Resolução e considerando o que dispõem os artigos $3^{\circ}, 6^{\circ}$ e $7^{\circ}$ do Decreto $n^{\circ} 750$, de 10 de fevereiro de 1993 , são estabelecidos os seguintes parâmetros básicos para análise dos estágios de sucessão da Mata Atlântica:

I - fisionomia;

II - estratos predominantes;

III - distribuição diamétrica e altura;

IV - existência, diversidade e quantidade de epífitas;

$V$ - existência, diversidade e quantidade de trepadeiras;

VI - presença, ausência e características da serapilheira;

VII - presença de subosque;

VIII - existência de diversidade e dominância de espécies;

IX - presença de espécies vegetais indicadoras.

E em seu Art. 3, descreve os estágios de regeneração da vegetação secundária, como sendo: inicial, médio e avançado.

\subsection{Bacia Hidrográfica do Alto Tietê}

A Unidade de Gerenciamento de Recursos Hídricos 06 (UGRHI 06) conforme figura 3, corresponde à área drenada pelo rio Tietê desde suas nascentes em Salesópolis, até a barragem de Rasgão, integrada por 34 municípios. O território compreendido por essa UGRHI ocupa grande parte da RMSP; dos municípios dessa região, apenas Guararema, Juquitiba e Santa Isabel não fazem parte da mesma. 


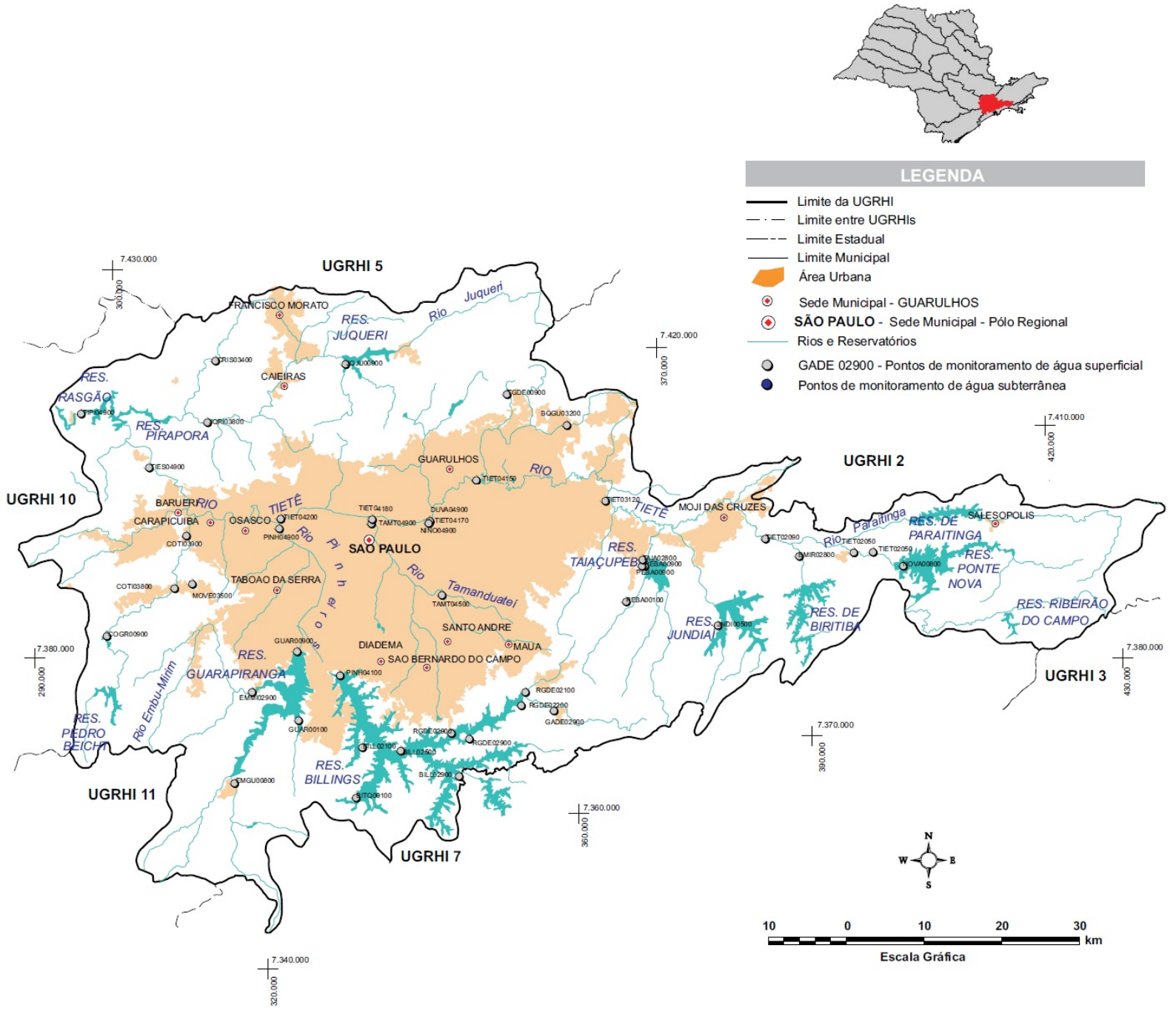

Figura 3 - Unidade de Gerenciamento de Recursos Hídricos número 06 -UGHRI 06 (SIGRH, 2015)

Grande parcela da área urbana da UGRHI 06 está sobre terrenos sedimentares de idade Cenozóica, abrangendo os depósitos terciários da bacia de São Paulo e as coberturas aluviais mais recentes de idade Quaternária, que foram desenvolvidas ao longo das principais bacias de drenagem dos rios da região. Com relação aos terrenos cristalinos, esses estão distribuídos para leste da bacia conduzindo às elevações compostas pela Serra do Mar de um lado e para noroeste constituindo parte da faixa de dobramento Açungui-São Roque. Os terrenos 
destacados acima, também compreendem as áreas mais recentes de expansão populacional na RMSP (DAEE, 2006).

Ocorre também uma estreita faixa de maciços florestais contínuos com pouca fragmentação nas áreas leste/sudeste, próxima à escarpa da Serra do Mar e sul/sudoeste, indicando ambientes mais conservados e em sequência com o maciço florestal atlântico. Ao Norte, em escala menor, ocorre significativa área de floresta mais isolada, como a Serra da Cantareira. Neste trecho da bacia do Tietê, as derivações ambientais causadas pela ocupação antrópica são muito marcantes (DAEE, 2006).

As 5 sub-regiões da Bacia Hidrográfica do Alto Tietê, divididas no ano de 1994 pelo Comitê da Bacia Hidrográfica do Alto Tietê (CBH-AT), conforme figura 4, incorpora municípios em sub-bacias, como, sub-bacia do Alto Tietê - Cabeceiras, sub-bacia Billings - Tamanduateí, sub-bacia Cotia - Guarapiranga, sub-bacia Juqueri - Cantareira e sub-bacia Pinheiros - Pirapora. E a desigualdade na distribuição de água nessa bacia é grave, onde a população é de aproximadamente 20 milhões de pessoas que consomem 400\% da disponibilidade de água, demonstrando sua criticidade hídrica (DAEE, 2006). 


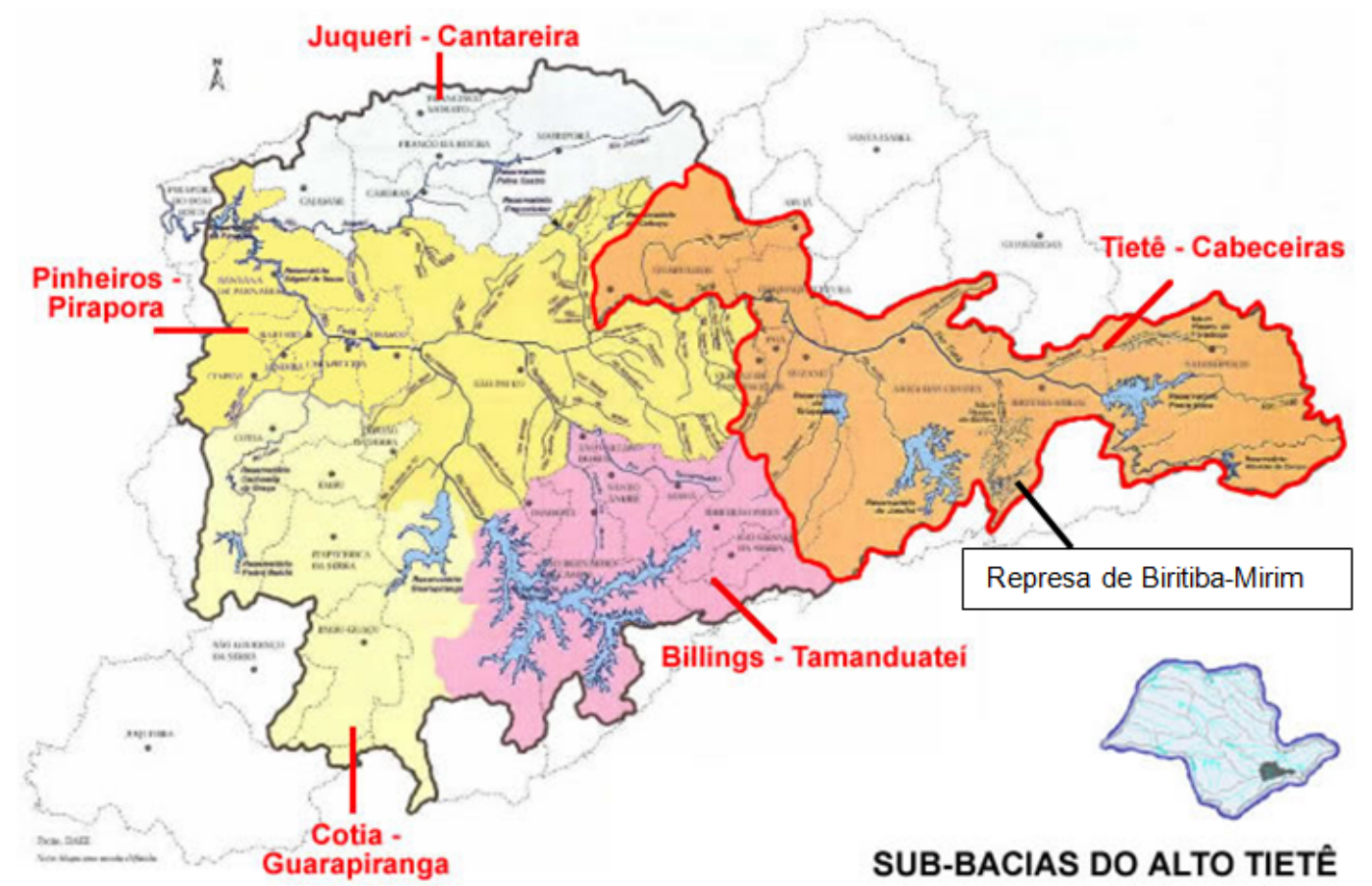

Figura 4 - Principais sub-bacias da bacia hidrográfica do Alto Tiete (Modificado de FIA, 2015)

A sub - bacia hidrográfica do Alto Tietê - Cabeceiras, constituída pelos rios Tietê (desde sua nascente até a divisa com Itaquaquecetuba), Claro, Paraitinga, Biritiba-Mirim, Jundiaí e Taiaçupeba-Mirim, possui área de 1.889 km² de drenagem; onde estão presentes os reservatórios Ribeirão do Campo e Ponte Nova (no município de Salesópolis), Jundiaí (em Mogi das Cruzes), Taiaçupeba (na divisa de Mogi das Cruzes e Suzano), Biritiba-Mirim (em Biritiba-Mirim) e Paraitinga (em Salesópolis), os dois últimos a entrarem em operação. O Sistema Produtor Alto Tietê (SPAT), é formado pelos reservatórios de Ponte Nova, Paraitinga, Biritiba-Mirim, Jundiaí e Taiaçupeba e foram concebidos e destinados a captação, armazenamento e tratamento de água para a Grande São Paulo. Estão inseridos em uma área de $1.196 \mathrm{Km}^{2}$, englobando as cabeceiras do rio Tietê e seus afluentes, onde ocorrem severas restrições ao uso e ocupação do solo (DAEE, 1997).

Os principais contribuintes do rio Tietê nas suas cabeceiras são os rios Claro, Paraitinga, Jundiaí, Biritiba-Mirim e Taiaçupeba que, juntamente com o próprio rio 
Tietê, compõem o quadro dos mais importantes mananciais de abastecimento da região, destacando-se os reservatórios Ponte Nova, Jundiaí e Taiaçupeba, projetados e implantados para abastecimento público como finalidade principal e, secundariamente, para controle de enchentes (SILVA; PORTO, 2003).

A Bacia Hidrográfica do Alto Tietê representa, como mencionado, um dos sistemas mais importantes de produção de água da RMSP, e o seu suprimento de água potável efetuado pelo Sistema Integrado de Abastecimento de Água é constituído por sete sistemas produtores (Sistema Cantareira, Sistema Guarapiranga, Sistema Alto Tietê, Sistema Rio Grande, Sistema Rio Claro, Sistema Alto Cotia e Sistema Baixo Cotia), entre os reservatórios do Sistema Produtor Alto Tietê (Ponte Nova, Ribeirão do Campo, Paraitinga, Jundiaí e Taiaçupeba), junto a esses se adiciona o reservatório de Biritiba-Mirim, destinado à captação, armazenamento e tratamento de água para a Grande São Paulo conforme ilustrado pela figura 5.

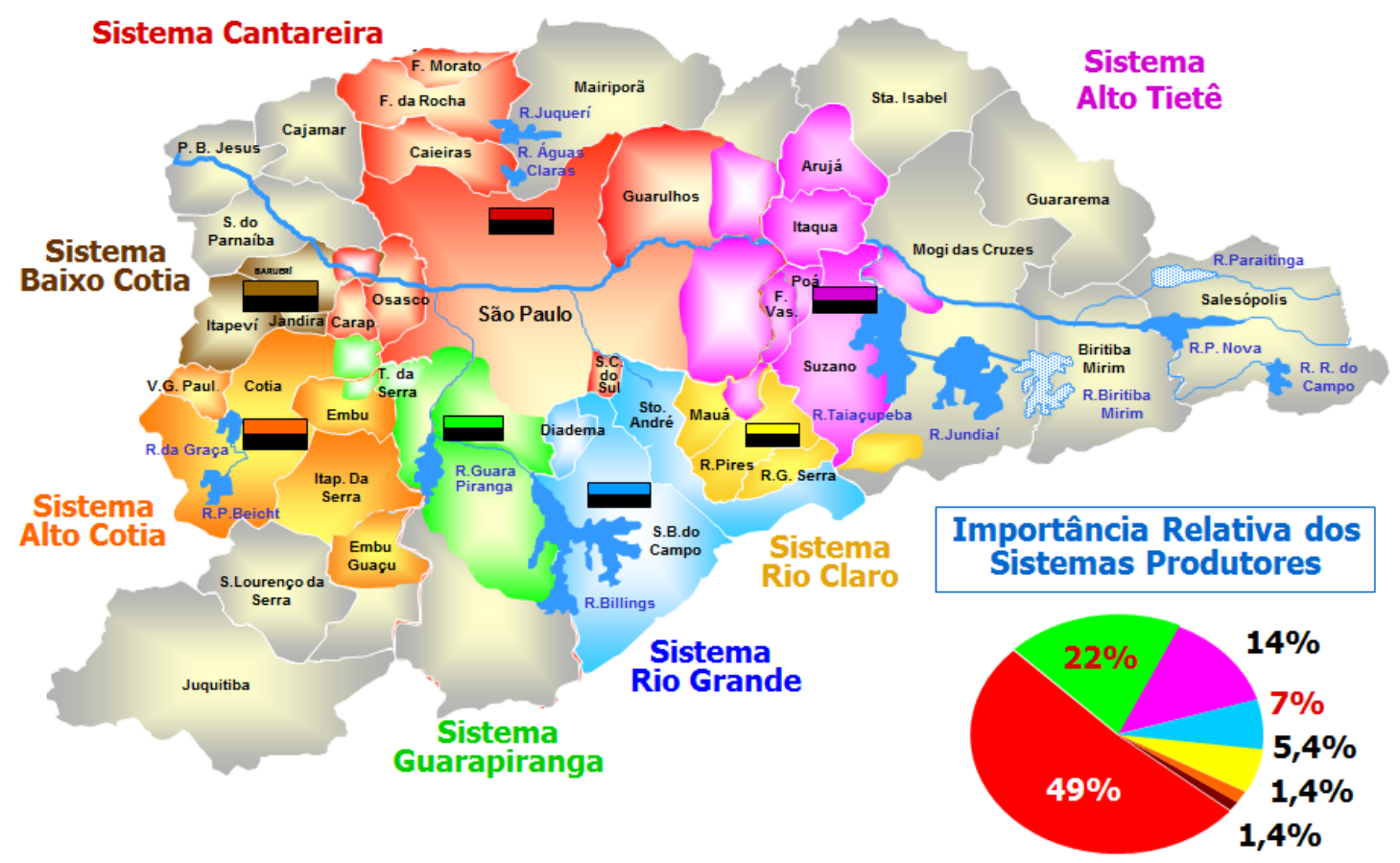

Figura 5 - Sistemas Produtores da RMSP (SABESP, 2015) 
Segundo Sendacz et al. (2005), o funcionamento do Sistema Produtor Alto Tietê, é realizado por um regime hidráulico em cascata onde as águas dos reservatórios de Ponte Nova e Paraitinga são parcialmente derivadas para uma estação elevatória, onde são recalcadas até o túnel de interligação Tietê/BiritibaMirim, onde está água é escoada por gravidade através de um canal, atingindo um braço do reservatório de Biritiba-Mirim (SP). Por meio de um sistema composto por canal-túnel-canal, a água é transferida por gravidade para o reservatório Jundiaí, e através de canal e por gravidade até o reservatório de Taiaçupeba, onde é realizada pela Companhia de Saneamento Básico do Estado de São Paulo (SABESP) a captação e tratamento na Estação de Tratamento de Água de Taiaçupeba (Figuras 6,7 e 8).

O sistema operado em cascata, foi implantado pelo Departamento de Água e Energia Elétrica (DAEE), é também administrado e operado em parceria com a SABESP desde junho de 1999, disponibilizando no momento $15 \mathrm{~m}^{3} / \mathrm{s}$ de água tratada para a RMSP, beneficiando mais de 4 milhões de pessoas (DAEE, 2011).

Segundo Sendacz et al. (2005), a configuração do sistema hidráulico dos reservatórios operando em cascata, é uma técnica de engenharia que pode proporcionar uma redução de possíveis contaminantes no percurso do sistema. Os sistemas de represamento em cadeia, com reservatórios posicionados a montante das captações, apresentem a função de reter parcela dos possíveis contaminantes e nutrientes, e como consequência garantir melhor qualidade das águas e sedimentos ao longo de seu deslocamento. Essa constatação não vem ocorrendo no decorrer da série de reservatórios do SPAT, pois, ao longo desse sistema, vem se observando crescimento do fenômeno da eutrofização. 
Os mesmos autores constatam que deve ser devido ao maior impacto antropogênico no entorno dos reservatórios a jusante, com maior pressão da mancha urbana e atividades agrícolas nesses reservatórios, em relação aos reservatórios mais a montante.

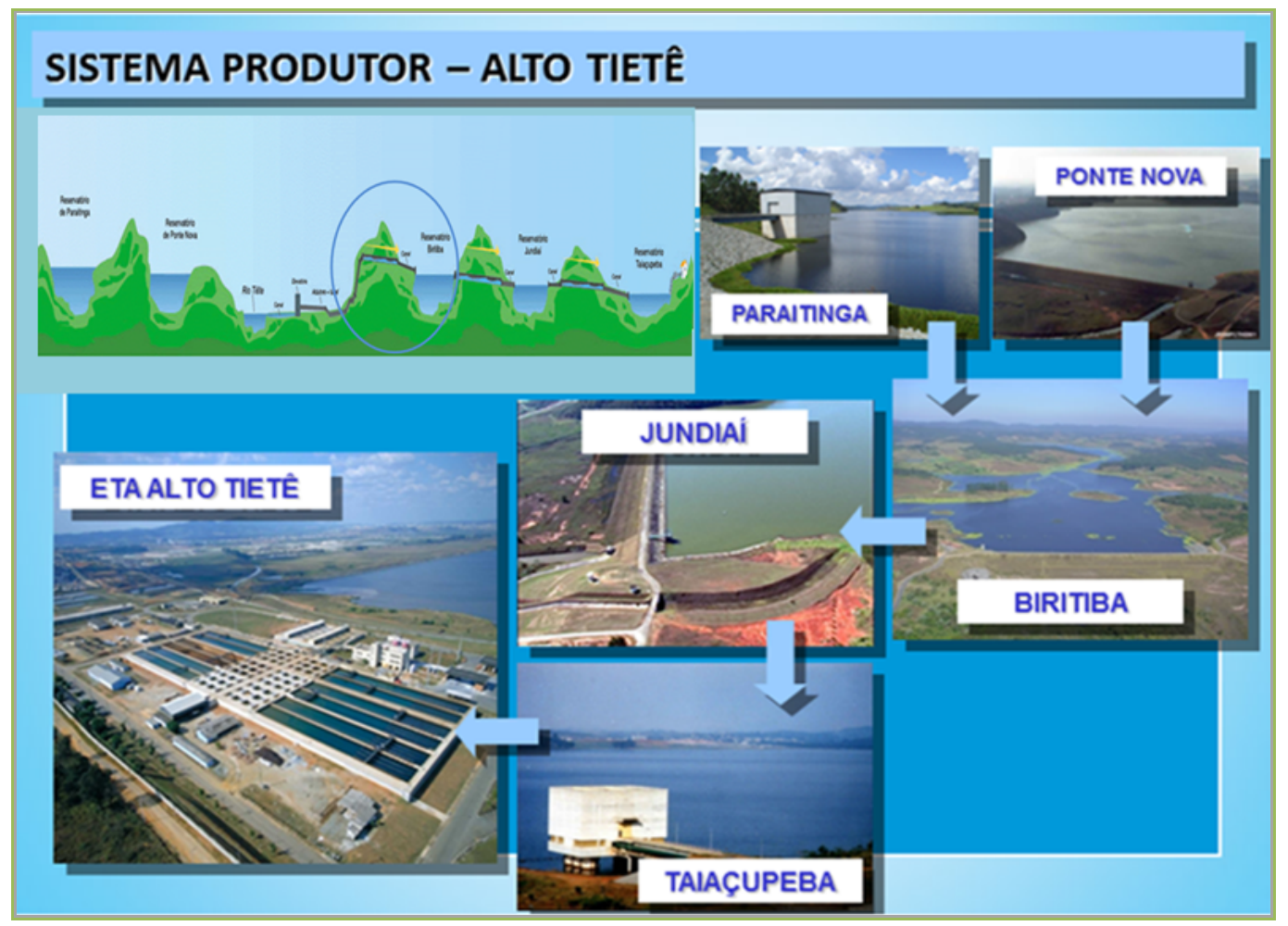

Figura 6 - Sistema Produtor Alto Tietê - SPAT (SABESP, 2015)

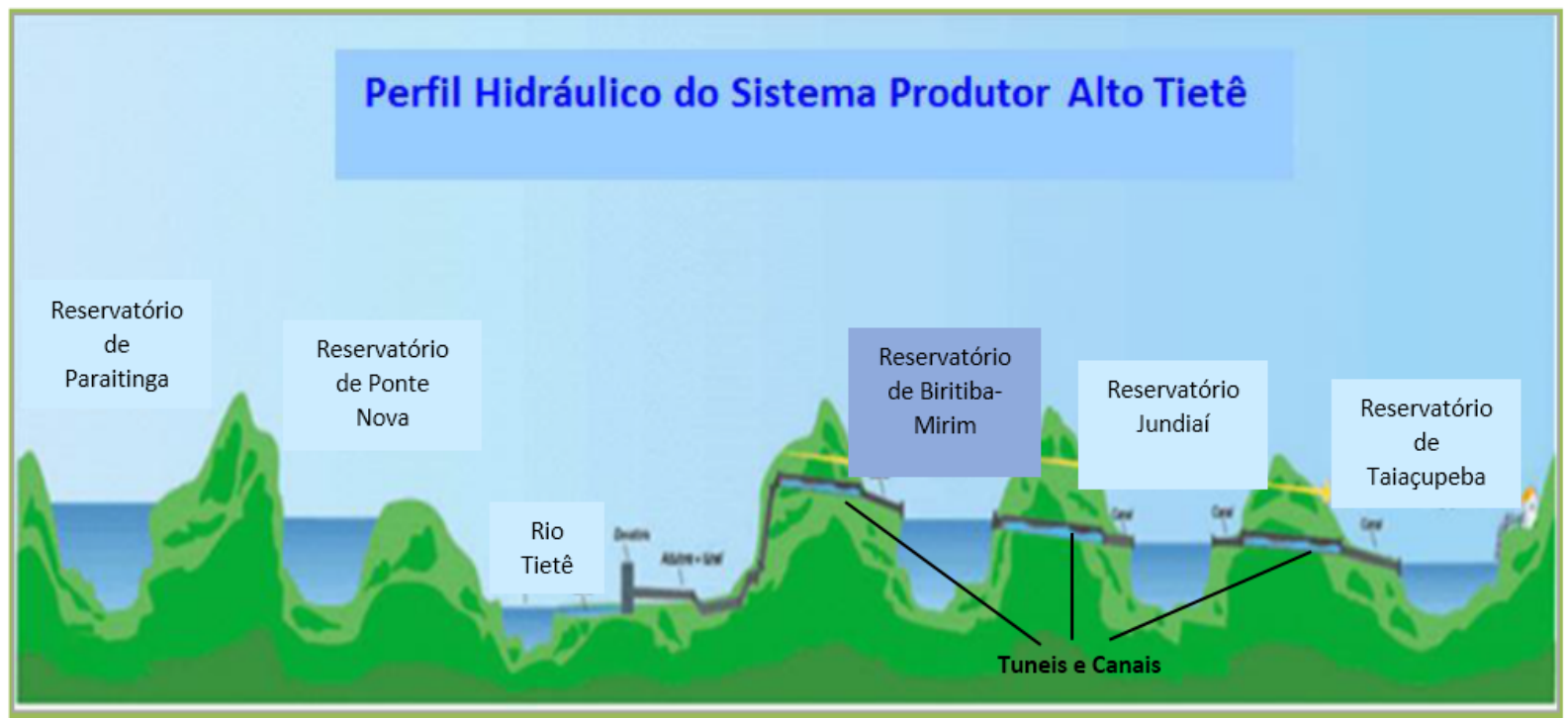

Figura 7 - Perfil Hidráulico do Sistema Produtor do Alto Tietê (SABESP, 2015) 


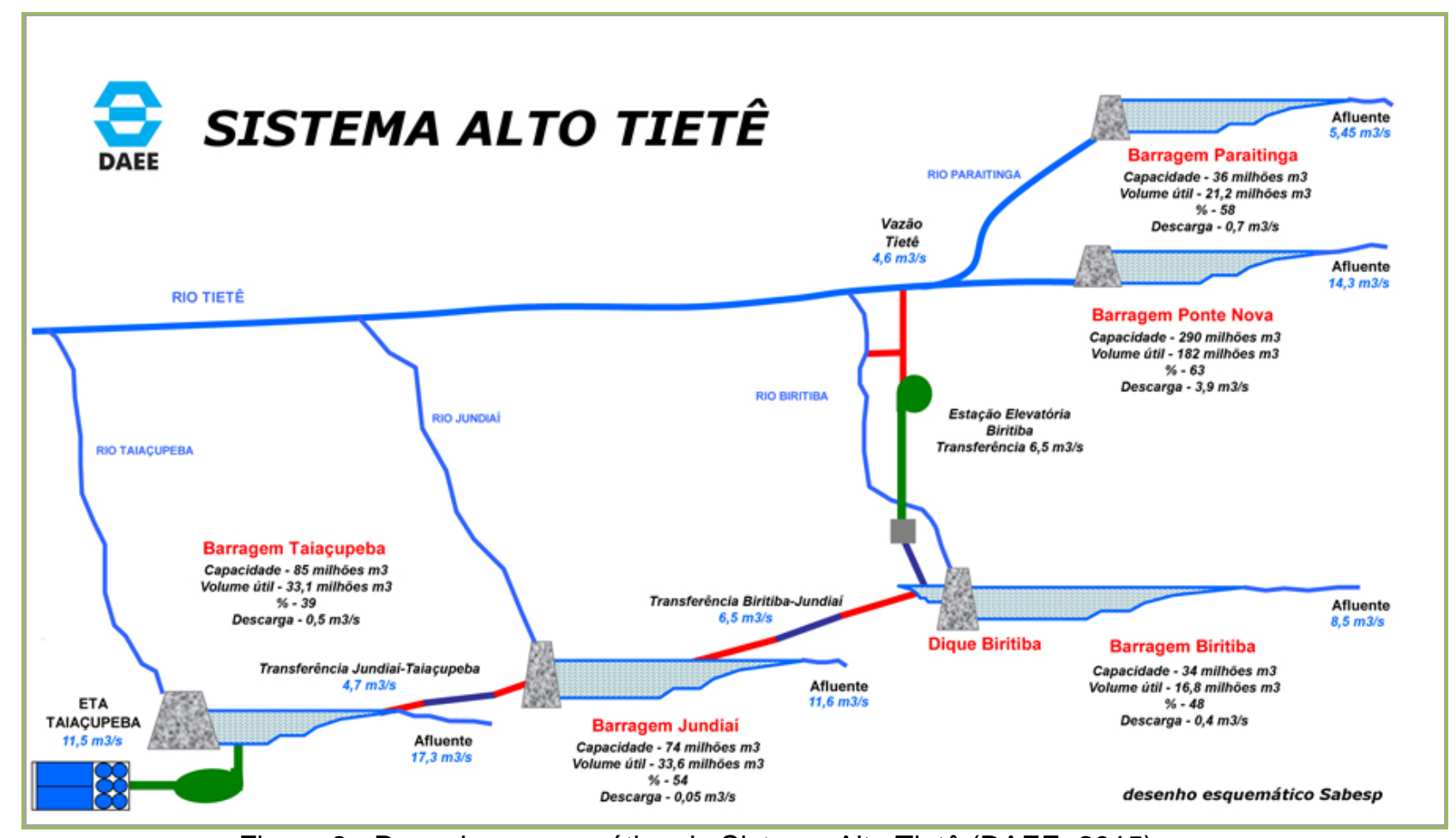

Figura 8 - Desenho esquemático do Sistema Alto Tietê (DAEE, 2015)

O reservatório de Biritiba-Mirim (SP) constituinte do Sistema Produtor Alto Tietê, que fornece água para aproximadamente 4 milhões de habitantes, principalmente para o leste da RMSP, foi uma das últimas barragens implantadas pelo DAEE na região das cabeceiras do rio Tietê, foi escolhido para este estudo, por apresentar áreas protegidas por mata ciliar e possivelmente estar sob influência de carga de poluentes oriundos de fontes difusas - resíduos da agricultura (fertilizantes, herbicidas, inseticidas, fungicidas, entre outros), bem como por se prestar a diversos usos como abastecimento urbano e industrial.

\subsection{Caracterizações da Área de Estudo}

\subsubsection{O município de Biritiba-Mirim (SP)}

O município de Biritiba-Mirim, está localizado a 780 metros de altitude, na microrregião de Mogi das Cruzes, na RMSP, no estado de São Paulo. Fazem 
limites com Biritiba-Mirim, os municípios de Guararema a norte, Salesópolis a leste, Bertioga a sul e Mogi das Cruzes a oeste e noroeste. (Figura 9).

Segundo IBGE, o município possui uma área de $317,406 \mathrm{~km}^{2}$, composto por bioma de Mata Atlântica e uma população de 28.575 habitantes.

Segundo Murillo (2008), Biritiba-Mirim (SP) apresenta sua economia baseada nos setores de horticultura, fruticultura e criação de aves, especialmente devido aos imigrantes japoneses que se estabeleceram na região no ano de 1929. Está inserida no chamado cinturão verde da RMSP. A denominação de Biritiba-Mirim tem como origem a língua tupi-guarani e tem como significado 'muitos buris pequenos', onde o buri é uma planta ornamental que produz flores coloridas.

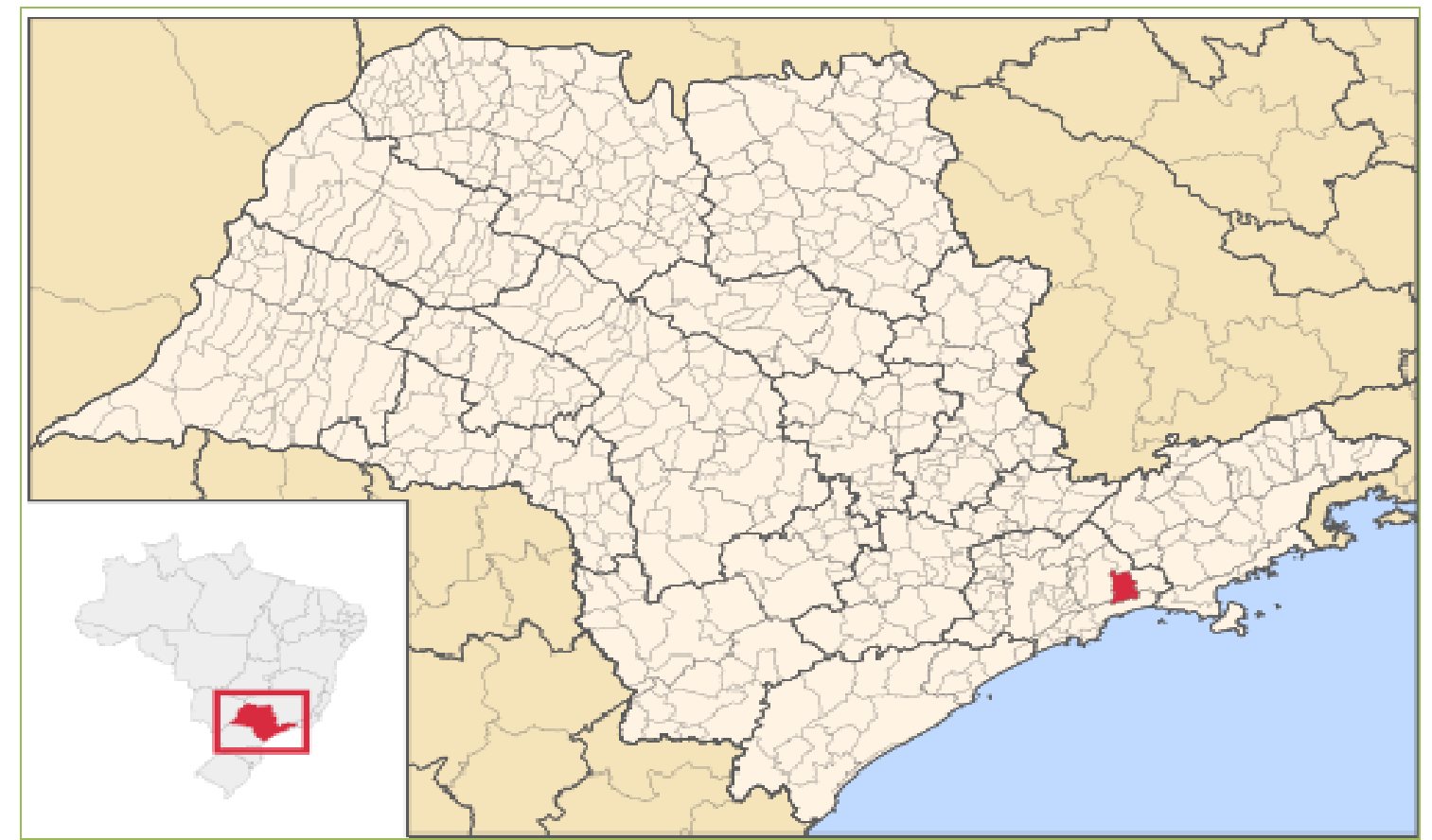

Figura 9 - Localização do município de Biritiba-Mirim no Estado de São Paulo (WIKIPEDIA, 2014)

\subsubsection{O Reservatório de Biritiba-Mirim (SP)}

Para desenvolvimento desta dissertação, a área escolhida encontra-se inserida na bacia de drenagem do médio e alto curso do rio Biritiba-Mirim, local onde foram escolhidas as duas áreas de amostragem na porção Leste do reservatório 
construído nesse sistema. As nascentes do rio Biritiba-Mirim estão localizadas na serra do Garrafãozinho, e seu fluxo segue a direção norte por 22 km, o encontro com o rio Tietê, montante a $11 \mathrm{~km}$ do município de Mogi das Cruzes (DAEE, 1997).

Este reservatório que é formado pelo represamento do rio Biritiba-Mirim, afluente da margem esquerda do rio Tietê, compreende as áreas dos municípios de Biritiba-Mirim e Mogi das Cruzes, onde ocupa uma área de inundação de 11,4 Km², apresentando $75 \mathrm{Km}^{2}$ de área de drenagem. O enchimento do reservatório de Biritiba-Mirim (SP) teve início em 13 de maio de 2005, atingido seu nível máximo em 21 de abril de 2006 (Dados fornecidos pelo engenheiro Luiz Carlos da Silva, responsável do DAEE de Biritiba-Mirim). O reservatório de Biritiba-Mirim (SP) é um dos reservatórios pertencentes ao Sistema Produtor Alto Tietê (SPAT) que é operado em conjunto pelo DAEE e pela SABESP, que produz água para aproximadamente 4 milhões de pessoas, entre outras características que podem ser vistas na Tabela 1. Apresenta também em sua área de inundação solos muito úmidos e grande quantidade de matéria orgânica, com muita fertilidade, onde é comum a presença em seu entorno de paisagens com características agrícolas, principalmente de hortaliças como: alface, couve e cogumelos (DAEE, 1997).

Segundo Cavalcanti (2002), as atividades de criação de aves e produção de ovos na área, também apresentam ocupação expressiva. 
Tabela 1 - Características gerais do reservatório de Biritiba-Mirim (SP)

\begin{tabular}{c|c}
\hline CARACTERISTICAS & DADOS \\
\hline Área & $11,4 \mathrm{~km} 2$ \\
\hline Área da bacia de drenagem & $75 \mathrm{~km} 2$ \\
\hline Formato & subdendrítico \\
\hline Volume acumulado & 60,2 milhões de $\mathrm{m}^{3}$ \\
\hline Volume operacional & $35 \mathrm{milhões} \mathrm{de} \mathrm{m}^{3}$ \\
\hline Tempo de detenção & $0,95 \mathrm{ano}$ \\
\hline Vazão regularizada & $1,75 \mathrm{~m}^{3} / \mathrm{s}$ \\
\hline Vazão máxima vertida para jusante & $30,50 \mathrm{~m}^{3} / \mathrm{s}$ \\
\hline Cota máximo operacional & $752,50 \mathrm{~m}$ \\
\hline Cota máximo normal & $757,50 \mathrm{~m}$ \\
\hline Cota máximo maximorum & $758,50 \mathrm{~m}$ \\
\hline Cota da crista & $760 \mathrm{~m}$ \\
\hline Comprimento da barragem & $500 \mathrm{~m}$ \\
\hline Altura máxima da barragem 2 & $6 \mathrm{~m}$
\end{tabular}

Fonte: DAEE, (2007).

\subsubsection{As condições climáticas do município de Biritiba-Mirim (SP)}

Segundo a classificação climática de Koppen, baseada em dados mensais pluviométricos e termométricos, o estado de São Paulo abrange sete tipos climáticos distintos, a maioria correspondente a clima úmido (CEPAGRI, 2015).

O município de Biritiba-Mirim (SP) apresenta o tipo Cwa, que abrange toda a parte central do Estado e é caracterizado pelo clima tropical de altitude, com chuvas no verão e seca no inverno, com a temperatura média do mês mais quente superior a $22{ }^{\circ} \mathrm{C}$ e pluviometria anual média de 1.364,2 mm (CEPAGRI, 2015).

A avaliação do índice pluviométrico no Reservatório de Biritiba-Mirim (SP) foi realizada tomando-se as médias mensais dos valores registrados na média histórica no período de 2002 a 2012, fornecido pelo DAEE local, e confrontado com o índice de 2013 até o presente momento, conforme apresentado no gráfico 1. O Gráfico 1 indica que a época chuvosa se estende de outubro a março e os meses mais secos concentram-se entre abril e setembro. 
No entanto dados coletados em 2013, mostram que o período considerado historicamente de estiagem, com precipitações mensais inferiores a $100 \mathrm{~mm}$, apresentou-se anômalo para esse ano, demonstrando aumento de intensidade pluviométrica atípico nos meses de junho/2013 e julho/2013, coincidentes com o período de amostragem do presente estudo.

O gráfico 1 também demonstra que os volumes superiores à média pluviométrica ocorridos em junho e julho foram equilibrados pelos índices inferiores de precipitações pluviométricas que ocorreram nos meses de abril, maio, agosto e setembro. Como previsível, o mês de janeiro apresentou o maior índice de pluviometria com $248,34 \mathrm{~mm}$, já o mês de agosto o menor, com $4,70 \mathrm{~mm}$.

Gráfico 1 - Intensidades de chuva mensais e anuais no Reservatório de Biritiba-Mirim (SP). dados obtidos de índice pluviométrico da barragem do rio Biritiba-Mirim

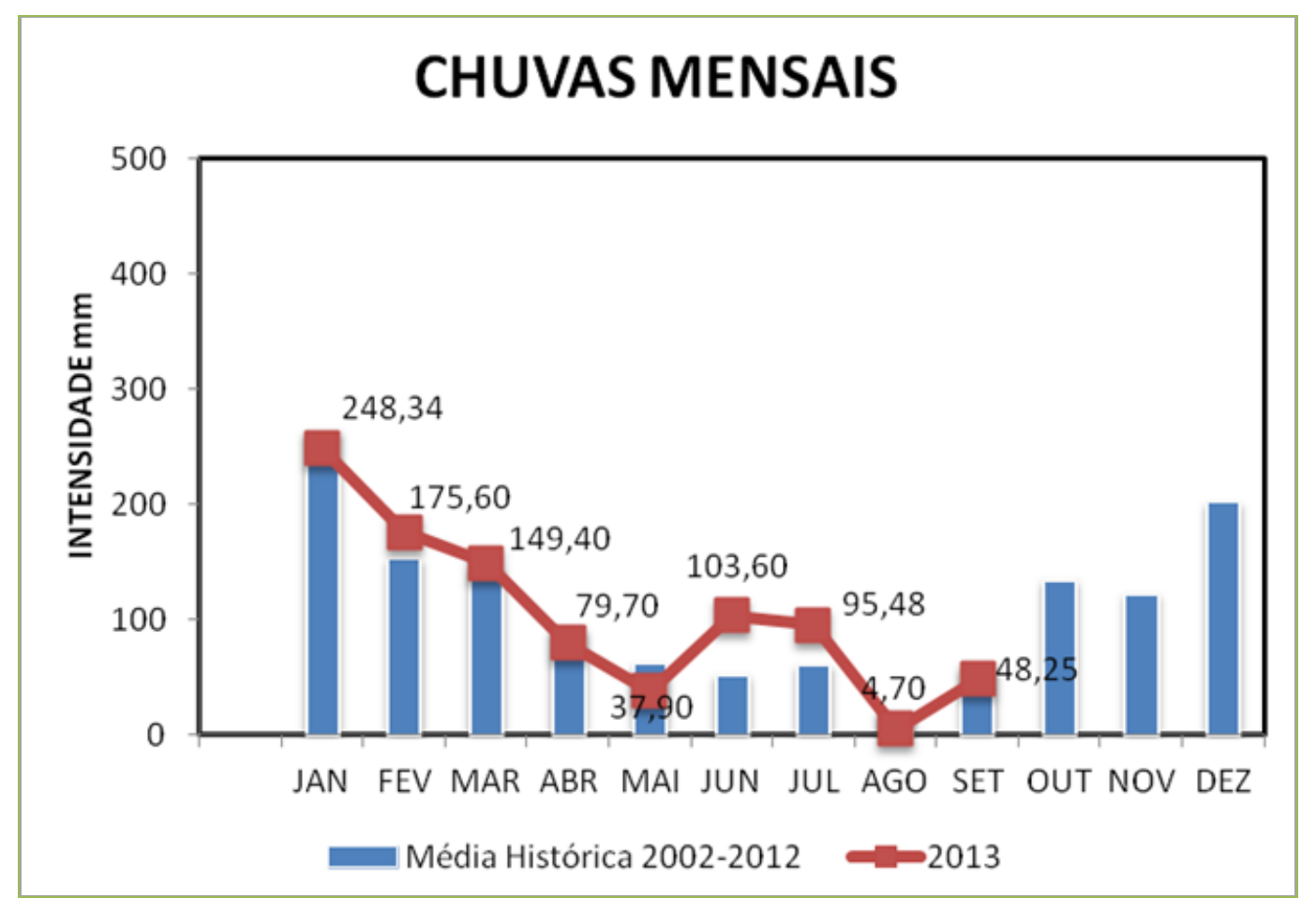

Fonte: DAEE, (2013). 
2.5.4 As características Geológicas da área do Reservatório de Biritiba-Mirim (SP)

O reservatório de Biritiba-Mirim (SP) é onde está inserida a área de estudo desta dissertação, apresenta situações tectônicas e geológicas distintas e diferentes unidades geológicas evoluídas. As unidades aflorantes principais da área estão representadas na figura 10. 


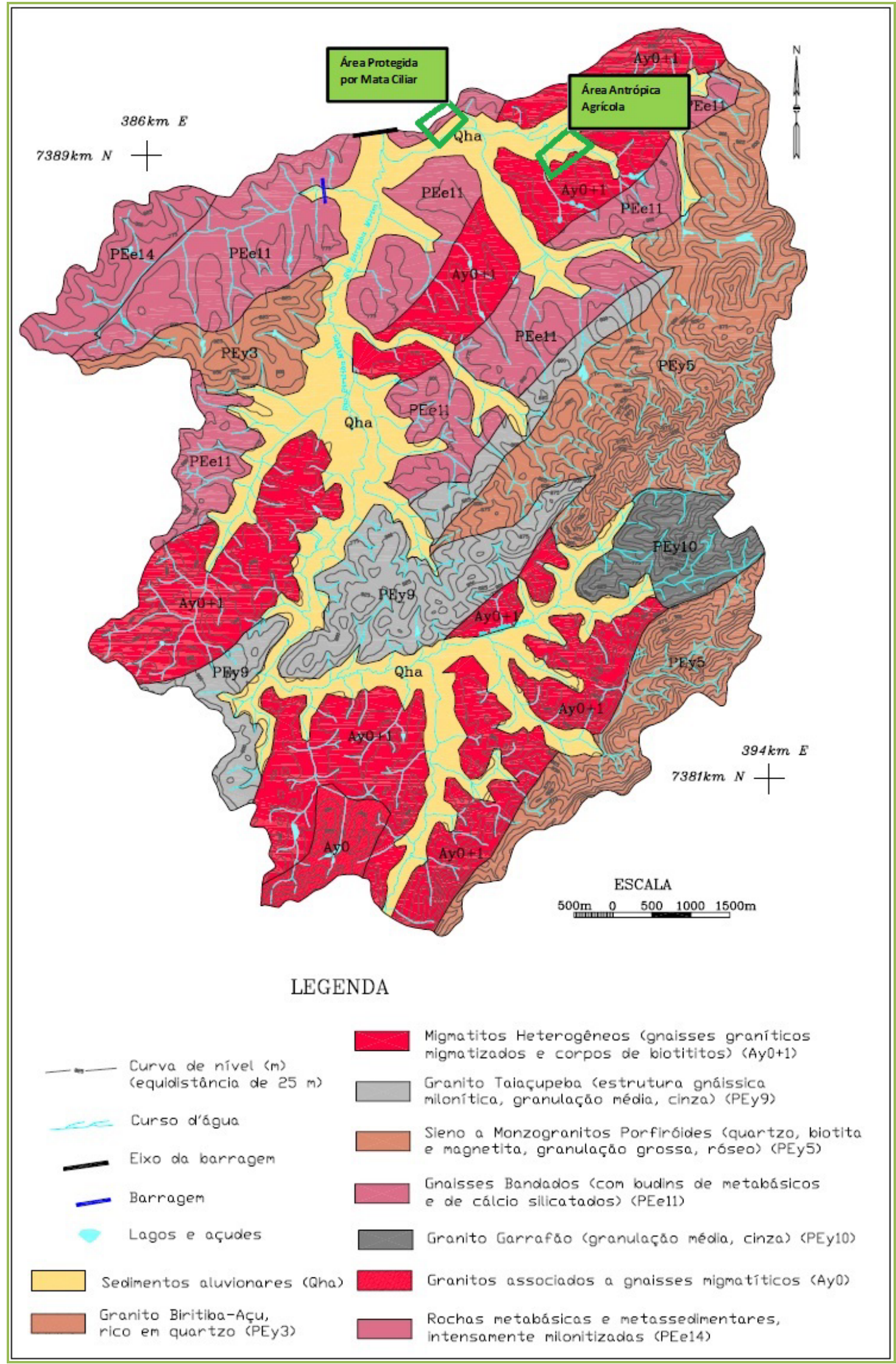

Figura 10 - Unidades geológicas na área de estudo (Fonte: Modificado de Cavalcanti, 2002) 
Com base em Hasui et al. (1981), o reservatório de Biritiba-Mirim (SP) objeto do presente estudo insere-se na região leste do planalto paulistano, ao sul do lineamento de Cubatão, tem em seu substrato um conjunto de rochas em conformidade ao lineamento de Cubatão, apresentando imersões acentuadas para noroeste, correspondentes a faixa costeira, localizadas no Complexo Costeiro.

A localização do Complexo Costeiro na porção Sul se apresenta em uma faixa alongada que se estende do centro-oeste a nordeste, constituído por rochas migmatíticas $(\mathrm{Ay} 0+1)$, apresentado textura variável, associados a corpos biotíticos e gnaisses graníticos. O complexo costeiro, também apresenta rochas graníticas de textura porfiróide (Ay0) na porção sul, intimamente associadas a gnaisses migmatíticos (CPRM, 1990).

$\mathrm{Na}$ porção leste e no extremo sudeste são encontrados sieno a monzogranitos porfiróides (PEy5), com características granulíticas grossa e apresentando coloração rósea, sendo potássicos e contendo alto teor de quartzo e biotita. Consistindo de biotita como principal máfico (CPRM, 1990).

Na porção norte do Complexo Embu, é onde ocorrem as rochas mais antigas (compreendendo um trecho da barragem com extensão para o Leste e Oeste), e Central pelas sequências metavulcanossedimentares fortemente milonitizadas e transformadas, representadas por metassedimentos, gnaisses paraderivados, rochas xistosas, quartzitos e subordinadamente rochas cálcio-silicáticas e metabásicas unidades PEe11 e PEe14 (CPRM, 1990).

Os corpos graníticos são encontrados nas unidades mais novas das rochas (CPRM, 1990). O Complexo Embu em sua porção Central ocorre o Granito Taiaçupeba (PEy9), presente no sentido sudoeste-nordeste, formado por sieno e monzogranitos, pouco orientado e foliados, por vezes porfiróides, equigranulares, 
homogêneos, de granulometria fina a média, cor cinza, localmente róseo ou esbranquiçado e apresentando raros xenólitos metassedimentares (CPRM, 1990). Complexo Embu em sua porção Centro-Leste, de caráter pós-tectônico, discordante, aflora a unidade muscovita-biotita granito, também conhecido como Granito Garrafão (PEy10), caracterizado por leuco-granitos de cor cinza esbranquiçados de textura equigranular, fina a média, a duas micas e composição sienogranítica (CPRM 1990).

Já o granito Biritiba-Açu (PEy3), presente na região oeste do Complexo, apresenta coloração rósea a cinza claro, com alto teor de quartzo, de textura equigranular ou porfiróide, com granulação média, e se apresenta encaixado em rochas migmatíticas (CPRM, 1990).

Os principais sistemas de drenagens do Complexo Embu, são encontrados nas unidades mais recentes, onde podemos destacar os depósitos fluviais (Qha), que se apresentam constituídos por camadas argilosas, ricas em material orgânico, areias inconsolidadas de granulometria variada e cascalhos. Sua extensão se apresenta restrita nas áreas de relevo acentuado e nos afluentes secundários (DAEE, 1997).

2.5.5 As características Hidrogeológicas da área do Reservatório de Biritiba$\operatorname{Mirim}(S P)$

De acordo com Cavalcanti (2002), o reservatório de Biritiba-Mirim (SP) está inserido em áreas onde as unidades hidrogeológicas estão relacionadas com as rochas do embasamento e sedimentos Quaternários das áreas de inundação, podendo ser diferenciada em dois grandes sistemas aquíferos: um Sistema Aquífero Sedimentar (SAS) e Sistema Aquífero Cristalino (SAC) (Figura 11). 
Segundo Cavalcanti6 (2002, apud HIRATA \& FERREIRA, 2001), o Sistema Aquífero Sedimentar (SAS) é formado por sedimentos quaternários e terciários da Bacia de São Paulo, apresentando depósitos sedimentares aluviais, onde se destacam os areno-argilosos, que ocupam com larguras irregulares as planícies das principais drenagens da área, apresentando tamanho entre 200 a 1.000 metros, e espessura média da ordem de 7 metros. Já o Sistema Aquífero Cristalino (SAC) é formado por granitos e rochas metamórficas do embasamento associadas com o Complexo Embu, Grupo São Roque e Serra do Itaberaba.

Segundo o DAEE (1975), o aquífero cristalino de ocorrência na região de Mogi das Cruzes apresenta profundidade aproximada entre 120 a 150 metros na RMSP e exibe capacidade específica média de $0,24 \mathrm{~m}^{3} / \mathrm{h} / \mathrm{m}$ e a transmissividade ao redor de 0,4 e $14 \mathrm{~m}^{2} /$ dia e entre 0,5 e $5 \%$ do coeficiente de armazenamento. A porosidade eficaz (Sy) é de 3\% (SABESP-CEPAS, 1994).

De acordo com Rebouças (1992), a condutividade hidráulica na porção intemperizada no Complexo Embu permanece entre $1 \times 10^{-3}$ e $1 \times 10^{-7} \mathrm{~m} / \mathrm{s}$ conforme a proximidade em relação à rocha intacta.

6 HIRATA, R. C. A. \& FERREIRA, L. M. R. Os aquíferos da bacia hidrográfica do Alto Tietê: disponibilidade hídrica e vulnerabilidade à poluição. Revista Brasileira de Geociências - Revista da Sociedade Brasileira de Geologia, São Paulo, v. 31, n. 1, p. 43-50, 2001. 


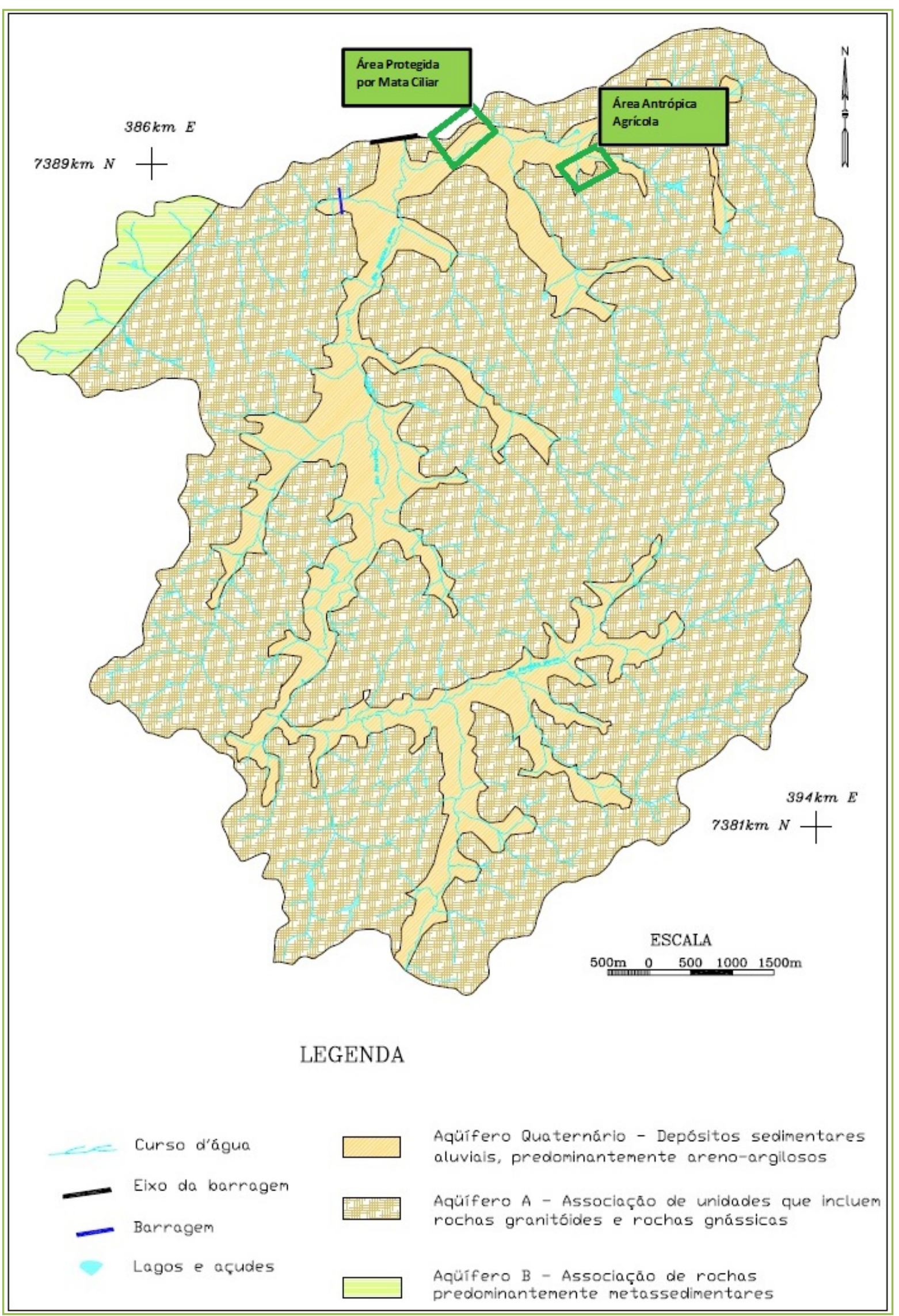

Figura 11 - Mapa hidrogeológico da área de estudo (Fonte: Modificado de Cavalcanti, 2002) 


\subsubsection{As características Pedológicas da área do Reservatório de Biritiba-Mirim (SP)}

Na região de Biritiba-Mirim (SP) é possível caracterizar diversos tipos de solos, que estão distribuídos em: Latossolo vermelho-Amarelo, Latossolo vermelhoescuro, Glei Pouco Húmico, Podzólico vermelho-amarelo e Cambissolo (DAEE, 1997).

Os Latossolos são solos com avançado estágio de intemperização, com predominância de argilominerais, não hidromórficos, variando entre muito profundos e profundos. Os Latossolos vermelho-amarelo e vermelho-escuro se diferem pelo teor de hidróxido de ferro que confere uma coloração mais escura quando em maior concentração (DAEE, 1997).

Os solos Glei Pouco Húmico são formados na presença de zonas mais úmidas e encharcadas de áreas planas e topograficamente baixas. Com deficiência de oxigenação apresentam um horizonte de coloração acinzentada resultado de modificações sofridas pelos óxidos de ferro existentes no solo (DAEE, 1997).

Os Cambissolos são encontrados em relevos acidentado e se apresentam como solos minerais com textura argilosa, com horizonte B câmbico, não hidromórficos, de caráter álico.

O solo Podzólico vermelho-amarelo se caracteriza por ser de baixa fertilidade, apresenta um grande acúmulo de argila nas camadas superficiais, possui solos minerais com horizonte $B$ textural, não hidromórfico, com sequência de horizontes $A$, B e C, bem moderadamente drenados (DAEE, 1997).

2.5.7 As características Geomorfológicas da área do Reservatório de Biritiba$\operatorname{Mirim}(S P)$

A bacia de drenagem do rio Biritiba-Mirim, é caracterizada por um alongamento no sentido Norte-Sul, sendo esse alongamento subdendrítico, que 
evidencia forte controle pelas estruturas das rochas do embasamento cristalino associadas à Zona de Cisalhamento de Cubatão. As unidades geomorfológicas presentes na área de estudo estão disponíveis na figura 12.

Segundo Ross e Moroz (1997), localizada no extremo leste do Planalto Paulistano, Biritiba-Mirim em termos geomorfológicos está limitada a sudeste pelo Planalto Paraitinga/Paraibuna, integrantes parciais da unidade morfoestrutural do Planalto Atlântico.

O rio Biritiba-Mirim, em sua cabeceira, apresenta uma paisagem formada por relevo de morros, serras e montanhas superiores a $100 \mathrm{~m}$ de altura e apresentando declividades médias a altas (PIRES NETO, 1992).

A existência marcante de planície fluvial (terrenos baixos e inclinados em direção ao canal) é característica das principais drenagens ao longo do reservatório, que se apresentam associadas a áreas alagadas e também pantanosas, que variam as altitudes de acordo com o relevo em que ocorrem (DAEE, 1997).

De acordo com Cavalcanti (2002), os relevos de colinas e morrotes favorecem as atividades agrícolas dessa região, pois apresentam amplitude entre 30 m a 75 m, vertentes com declividades baixas de $10 \%$ a $15 \%$ e altitudes variáveis de $780 \mathrm{~m}$ a $800 \mathrm{~m}$, que minimiza o processo de escoamento superficial e como consequência remove os produtos aplicados no solo. Isto também aliado a unidade do Complexo Embu e de grande fertilidade.

Segundo o mesmo autor, os relevos de Morros, Serras e montanhas também estão presentes na área de estudo, com amplitudes variando de 100 m a 420 m, e vertentes com declividades de $20 \%$ a $53 \%$. Já os morrotes paralelos se apresentam $40 \mathrm{~m}$ a $90 \mathrm{~m}$ de amplitude, vertentes com declividades de $23 \%$ a $50 \%$ e perfil retilíneo, seus topos e vales são estreitos, padrão de drenagem em treliça e paralelo 
de alta densidade. Quanto aos morrotes e morros, as amplitudes são de $60 \mathrm{~m}$ a 160 m, possuem ainda vertentes com declividades de $13 \%$ a $40 \%$, constituindo topos de morros e morrotes amplos, de forma convexa e configuração de topos estreitos, os vales se apresentando estreitos e com padrão de drenagem dendrítico e subparalelo, de média a alta densidade.

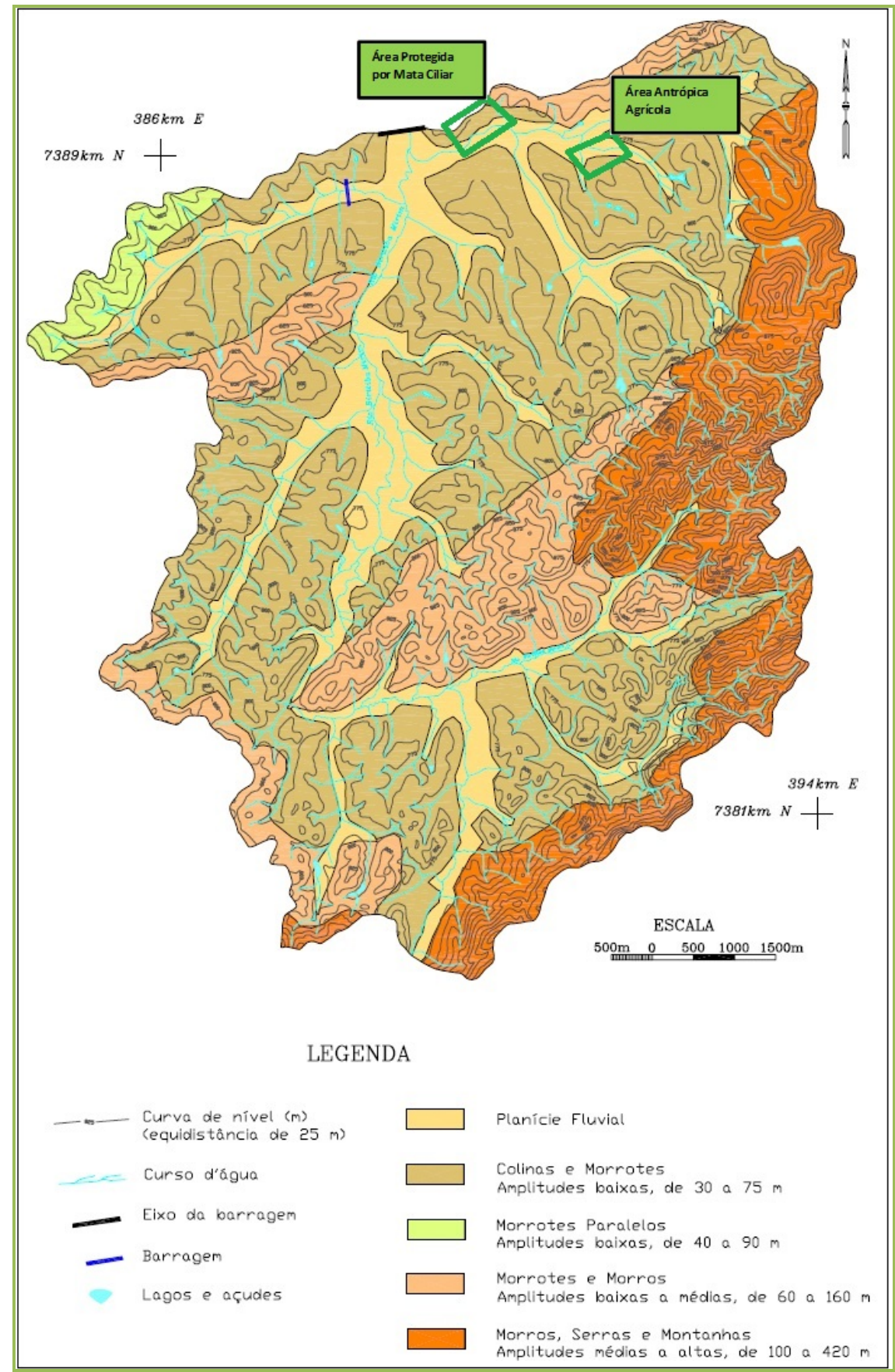

Figura 12 - Unidades geomorfológicas na área de estudo (Fonte: Modificado de Cavalcanti, 2002) 


\subsubsection{O uso e Ocupação do Solo da área do Reservatório de Biritiba-Mirim (SP)}

Analisando a figura 13, constata-se que as principais atividades realizadas no entorno do reservatório de Biritiba-Mirim (SP) são identificadas como sendo: agricultura, com culturas anuais e perenes; áreas de reflorestamento para produção de celulose; e atividade granjeira objetivando principalmente a produção de ovos. Observa-se presença de chácaras e sítios de veraneio e agricultura de subsistência. Ocorrem também atividades industriais a noroeste e sudeste da área, como relatado acima, para produção de papel e celulose.

Segundo Monteiro7 (2006, apud URUKAWA, 2011), e observando a figura 13, as porções com solo exposto se apresentam em pequena quantidade na área. Ocorrem também atividades comerciais, agroindustriais, pesca e turismo, mais precisamente voltado ao descanso e lazer.

De acordo com Cavalcanti (2002), a bacia hidrográfica onde se insere o reservatório de Biritiba-Mirim (SP) é caracterizada pela presença de solos ricos em alumínio e ferro. Destaca-se também a presença de vegetação florestal nativa e atividades voltadas a agricultura e pecuária.

Segundo dados do Levantamento Censitário das Unidades de Produção Agropecuária do Estado de São Paulo - LUPA 95/96 e 07/08, verifica-se que ocorreu acréscimo de $5.152,5$ ha para 5.469 ha de reflorestamento, de $7.998,5$ ha para 8.404,8 ha de vegetação natural e principalmente de 1,56\% para 16,7\% das práticas de conservação de solo, no município de Biritiba-Mirim (SP) (SÃO PAULO, 2008).

Conforme figura 14, o órgão gestor DAEE, desapropriou uma área de 6,65 $\mathrm{Km}^{2}$, em cumprimento a legislação e ao licenciamento ambiental do reservatório,

\footnotetext{
${ }^{7}$ MONTEIRO, M. D. Avaliação do conteúdo de metais e defensivos agrícolas na área de influência do reservatório de Biritiba-Mirim (SP). 2006. Trabalho de Formatura. Instituto de Geociências da Universidade de São Paulo. São Paulo, 47p.
} 
limitando as Áreas de Preservação Permanente com uma largura mínima de $30 \mathrm{~m}$ e máxima de $100 \mathrm{~m}$ em projeção horizontal, objetivando principalmente, garantir a quantidade e a qualidade da água do reservatório de Biritiba-Mirim (SP).

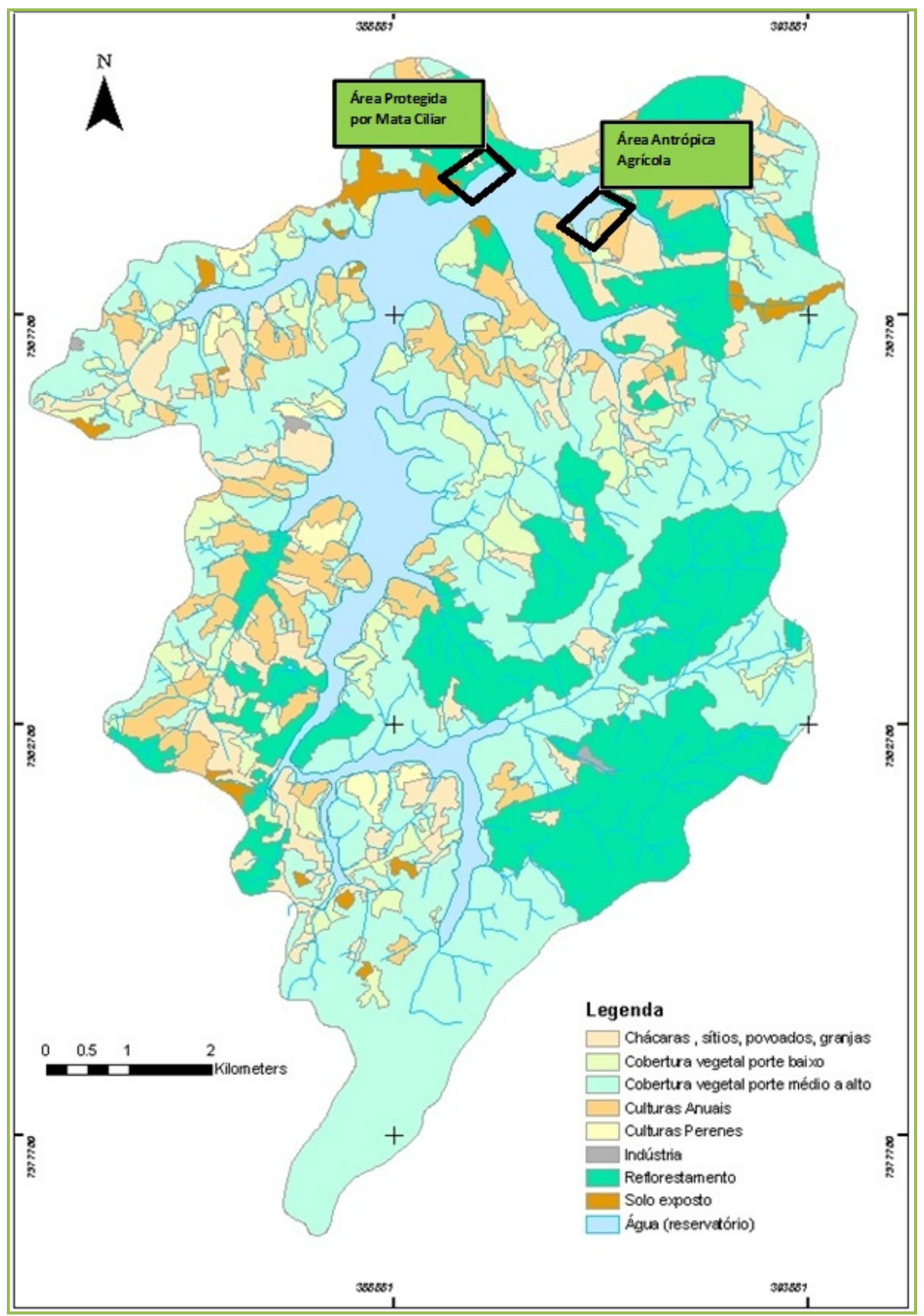

Figura 13 - Mapa de uso e ocupação do solo (Fonte: Modificado de Monteiro8 (2006, apud URAKAWA, 2011)

8 MONTEIRO, M. D. Avaliação do conteúdo de metais e defensivos agrícolas na área de influência do reservatório de Biritiba-Mirim (SP). 2006. Trabalho de Formatura. Instituto de Geociências da Universidade de São Paulo. São Paulo, 47p. 


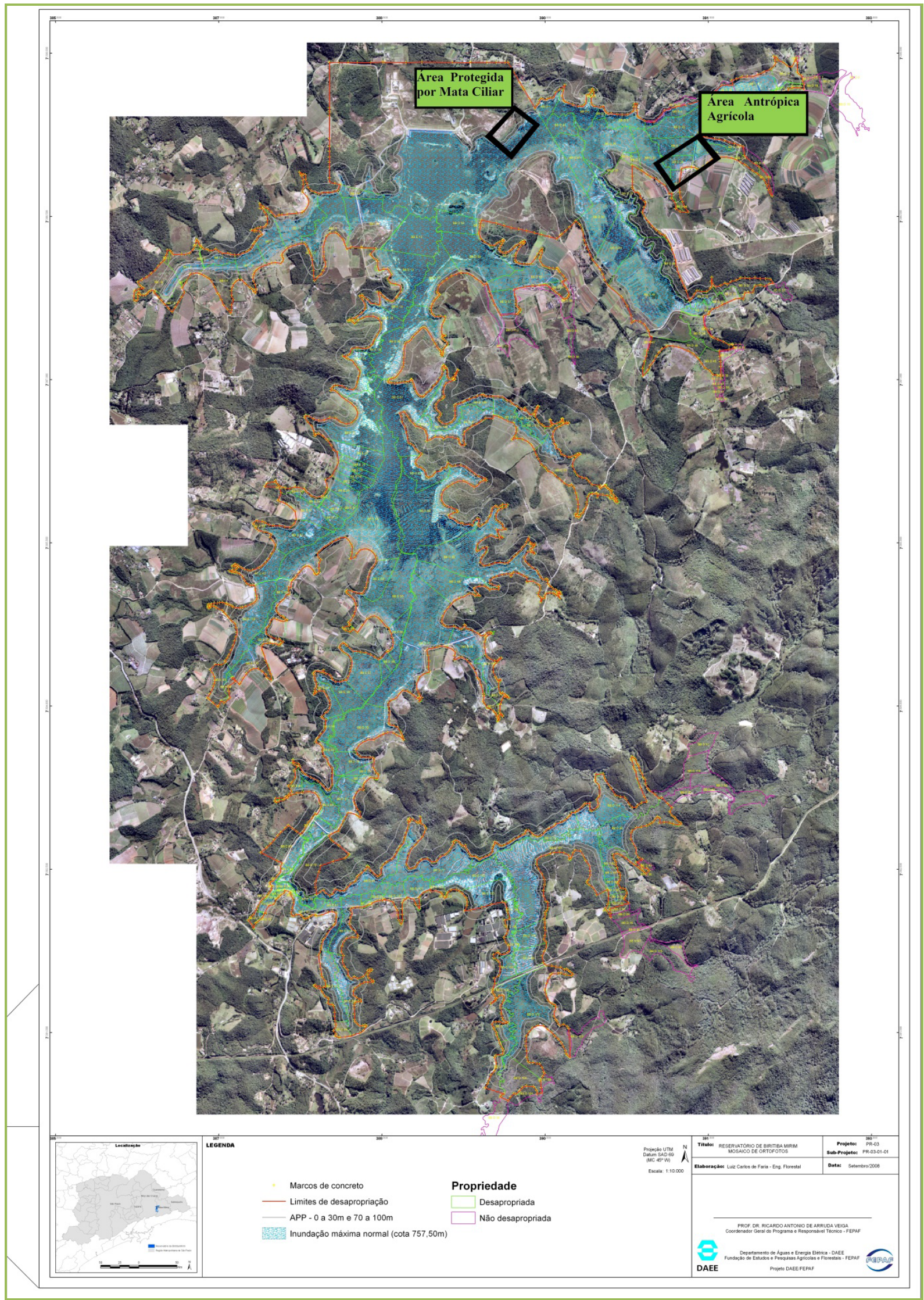

Figura 14 - Mapa de desapropriação. (Fonte: Modificado de FARIA, 2008) 


\subsubsection{A vegetação Natural existente na Bacia Hidrográfica do Alto Tietê}

A Bacia Hidrográfica do Alto Tietê ocupa uma área de 565.000 ha, de acordo com seus limites físicos, apresentando 134.260 ha de vegetação natural remanescente que correspondem a $23,8 \%$ de sua superfície.

As categorias de maior ocorrência são a Floresta Ombrófila Densa Montana (38.292 ha) e sua correspondente formação de Vegetação Secundária (93.349 ha).

A vegetação remanescente (134.260 ha) está dividida em 4.491 fragmentos, sendo que deste total 2.919 (65\%) apresentam superfície até 10 ha e 677 até 20 ha. Observa-se, portanto, que 3.596 fragmentos $(80,1 \%)$ apresentam superfície entre 0 e 20 ha.

Em termos de cobertura florestal, originalmente o município de Biritiba-Mirim (SP) se encontrava nos domínios do bioma da Mata Atlântica, mais precisamente na Floresta Ombrófila Densa, segundo Inventário Florestal da Vegetação Natural do Estado de São Paulo da Secretaria do Meio Ambiente/Instituto Florestal (2005) (Figura 15) (SÃO PAULO, 2005).

\subsubsection{A descrição de Floresta Ombrófila Densa na área desta dissertação}

A região fitoecológica floresta ombrófila densa, também conhecida como floresta pluvial tropical - Floresta Amazônica e Floresta Atlântica, onde está inserida a área de estudo desta dissertação é caracterizada por fanerófitos, lianas e epífitas se apresentando em grande quantidade. A floresta ombrófila densa também é caracterizada pela ocorrência em elevadas temperaturas e precipitações, com temperatura média de $25^{\circ} \mathrm{C}$. As chuvas são bem distribuídas no ano, onde a temporada mais seca varia de 0 a 60 dias. As características dos solos dominantes desse tipo de vegetação são os Latossolos Vermelho Distroférricos (Latossolo roxo distrófico) e excepcionalmente os Latossolos Vermelho Eutroférricos (Latossolo roxo 
eutrófico). Esses solos têm origem de granitos e gnaisses, bem como de arenitos em associação a derrames vulcânicos de vários períodos geológicos. A região fitoecológica ombrófila densa foi subdividida em cinco faciações dispostas conforme a hierarquia topográfica das diferentes fisionomias, conforme as faixas altimétricas e suas variações ecotípicas: floresta ombrófila densa aluvial, floresta ombrófila densa das terras baixas, floresta ombrófila densa submontana, floresta ombrófila densa montana e floresta ombrófila densa altomontana (EMBRAPA, 2014).

Segundo São Paulo (1994), o estágio succecional, na fisionomia Ombrófila Densa, que ocorre na área de estudo desta dissertação, é o Estágio Médio, onde apresenta fisionomia florestal com presença de estratos de diferentes alturas, 0 estrato superior é uniforme com árvores emergentes. Aparecem epífitas, trepadeiras, serrapilheira com variações de espessura. A diversidade é significativa com espécies de rápido crescimento. Em geral ocorrem indivíduos das seguintes espécies: copaíba (Copaifera langsdorfii), monjoleiro (Acacia polyphylla), mamicade-porca (Zanthoxyllum riedelianum), canelas (Ocotea sp., Nectandra sp.), ipês (Tabebuia sp.), guapuruvu (Schizolobium parahyba), açoita cavalo (Luehea divaricata), cedro (Cedrela fissilis), angico (Anaderanthera sp) e pau-jacaré (Piptadenia gonoacantha). 


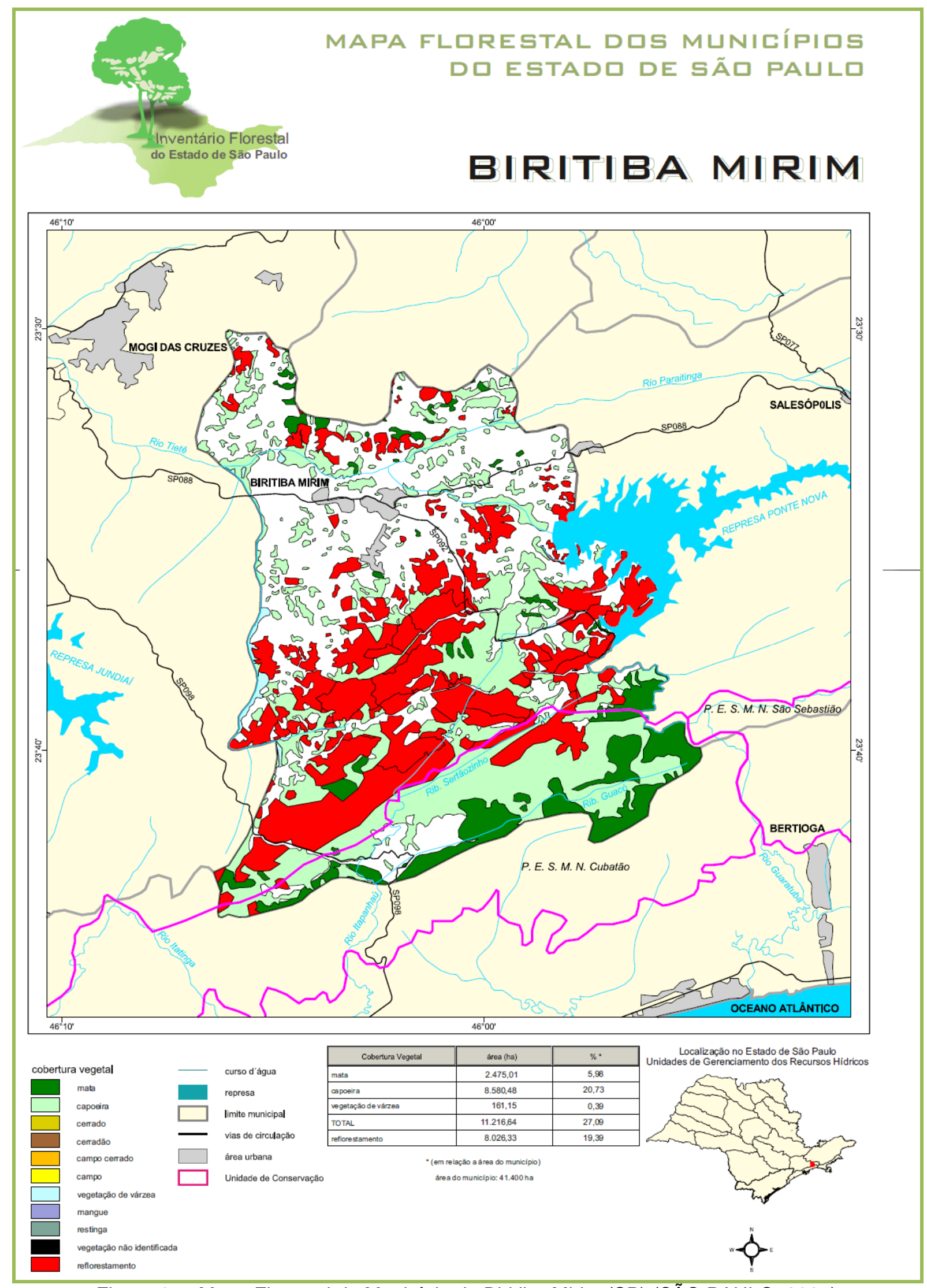

Figura 15 - Mapa Florestal do Município de Biritiba-Mirim (SP) (SÃO PAULO, 2005) 


\section{OBJETIVO}

\subsection{Geral}

O objetivo geral desta dissertação é avaliar as condições ambientais (elementos químicos e condições físico-químicas) provindas de atividade antrópica que se inserem no reservatório de Biritiba-Mirim (SP) comparando com áreas que se encontram protegidas por mata ciliar.

\subsection{Específico}

Determinar parâmetros físico-químicos: Potencial Hidrogeniônico $(\mathrm{pH})$, Condutividade Elétrica (CE), Oxigênio Dissolvido (OD), Potencial de Oxirredução (ORP), Temperatura $\left(\mathrm{T}^{\circ} \mathrm{C}\right)$ e Turbidez (NTU), de águas em dois setores do reservatório em um número de amostras que permita uma diagnose segura dessas condições. Amostras de água foram coletadas para determinação química de multielementos segundo critérios da SABESP de determinação de potabilidade de água para consumo humano, adaptados a água bruta. Nos mesmos locais foram amostrados sedimentos de fundo para análises químicas totais do conteúdo de elementos, buscando associar com compostos de degradação de rocha versus compostos utilizados em atividade agrícola. Os dois setores de coleta estão localizados na porção Leste do Reservatório de Biritiba-Mirim (SP), um com franja de atividade antrópica agrícola proximal a lâmina de água do reservatório e o outro em setor sem qualquer atividade importante agrícola e preferencialmente protegido por mata ciliar. Os resultados desta investigação nesses dois setores foram comparados um contra o outro. 


\section{MATERIAIS E MÉTODOS}

As caracterizações geológicas, hidrológicas, pedológicas, de vegetação e de uso e ocupação do solo da área de estudo, foram realizadas através de consulta em trabalhos prévios que tiveram suas atividades desenvolvidas, seja na área de estudo, seja como também em áreas maiores, onde a área de estudo está inserida.

Posteriormente as incursões em campo para reconhecimento e escolha da área de estudo e dos pontos de amostragem, foram utilizadas imagens do satélite LANDSAT 5, mapas topográficos, em escala 1:10.000 elaborados por EMPLASA (1996), assim como os mapas geológicos, geomorfológicos e hidrogeológicos, em escalas 1:50.000 e 1:25.000, respectivamente produzidos por DAEE (1997) e Cavalcanti (2002).

Foi realizada também a captação das imagens da área de estudo no Reservatório de Biritiba-Mirim (SP) - Bacia Hidrográfica do Alto Tietê através do site da EmplasaGeo - EMPLASA (EMPRESA PAULISTA DE PLANEJAMENTO METROPOLITANO SA). As imagens elegidas pertencem ao satélite LANDSAT 5.

Posteriormente a extração das imagens, foi realizada aproximação e corte das imagens, através dos programas Paint e Word, visando a análise exclusivamente da área de estudo, na porção Leste do reservatório de Biritiba-Mirim (SP), pertencente a Bacia Hidrográfica do Alto Tietê (Figura 16). 


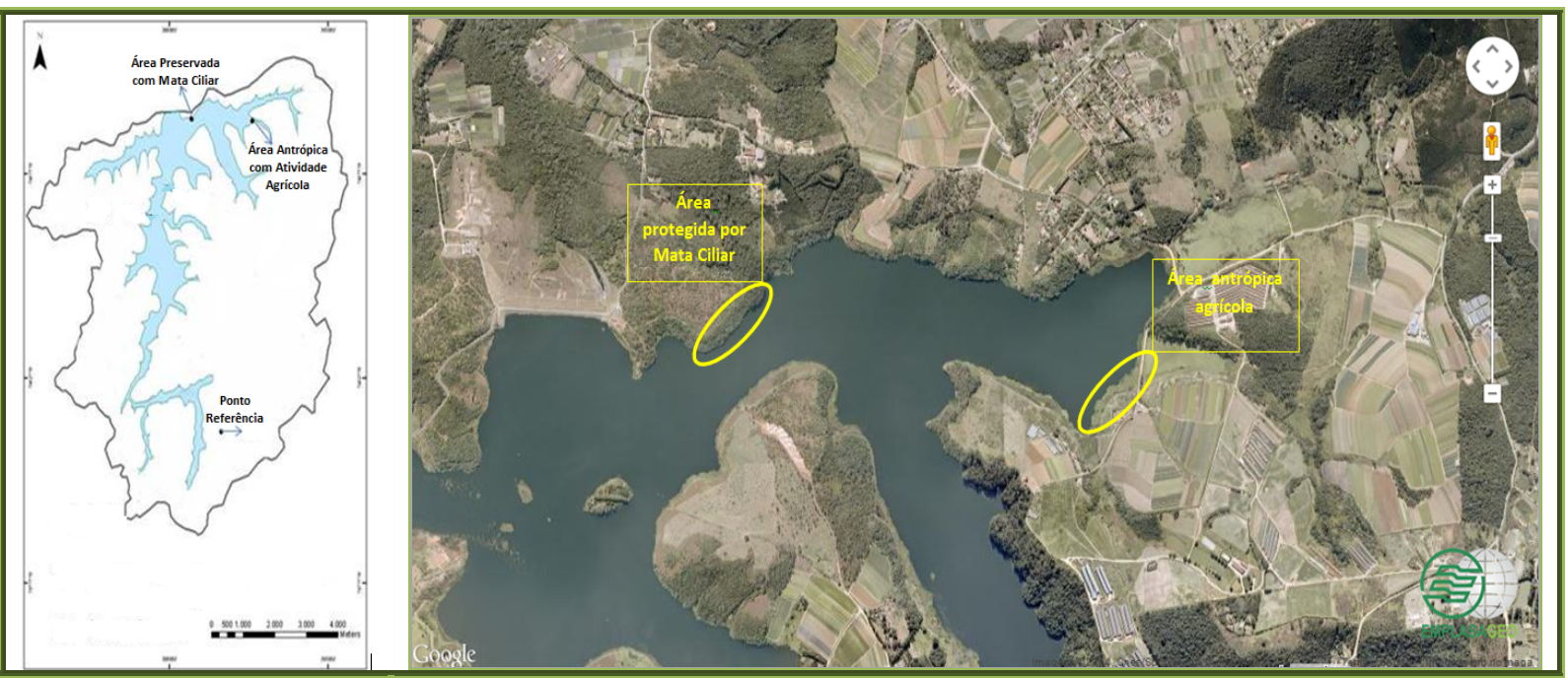

Figura 16 - Imagem do LANDSAT 5 da Reservatório de Biritiba-Mirim (SP), com destaque das áreas de amostragens - (Fonte: MAPEIA, 2014)

\subsection{Trabalhos de Campo}

Os trabalhos de campo foram realizados por meio de três incursões em campo, nos dias 12/06/2013, 18/06/2013 e 11/07/2013, para a seleção e avaliação da área de estudo, onde foi efetivada a seleção dos pontos de amostragens, as determinações analíticas "in situ" das amostras líquidas de água e amostragens de sedimento de fundo. A metodologia para determinação dos pontos de amostragem foi realizada considerando principalmente a representatividade ambiental para o objetivo do estudo e a facilidade de acesso.

Para realização desses trabalhos foi utilizado um veículo automotor pertencente ao Instituto de Geociências da Universidade de São Paulo - IGc - USP, para deslocamento pela bacia hidrográfica e identificação do ponto de afluência do Ribeirão Biritiba-Mirim, que representa uma das áreas de recarga do reservatório, considerado como ponto referência. (Figuras 17A e 17B). 

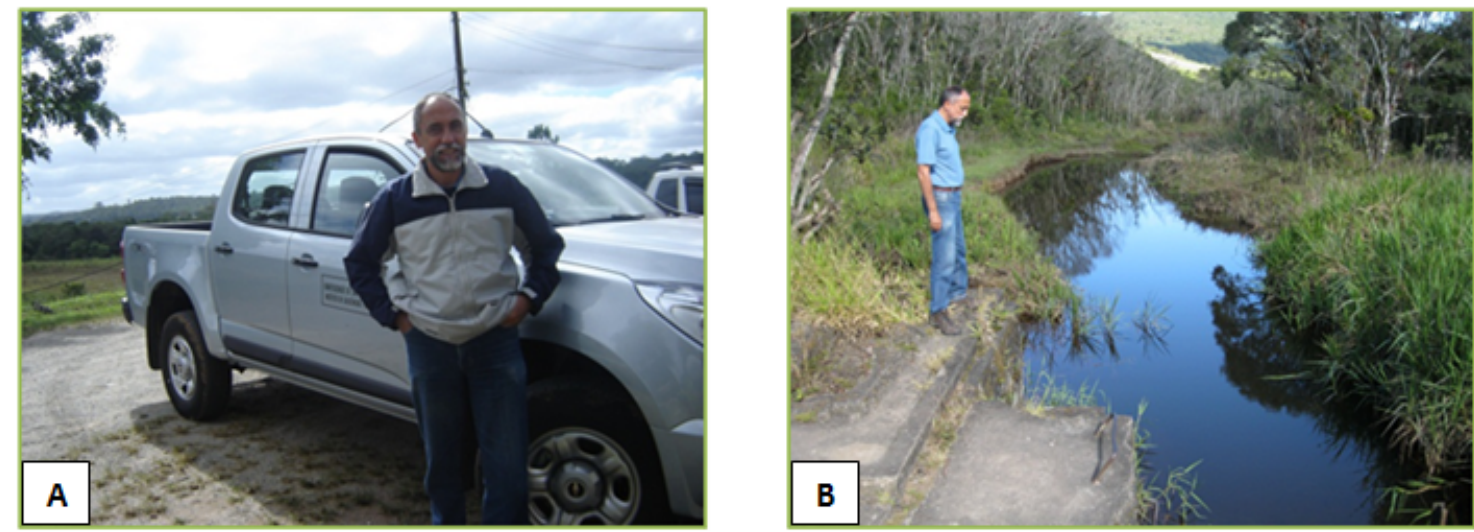

Figura 17A e 17B - A - Visita a campo para reconhecimento da área de estudo. Fonte: J.B.Sígolo B - Seleção dos pontos de amostragem e visita de parte do Ribeirão Biritiba-Mirim. Fonte: J.B.Sígolo.

Um barco de alumínio de cinco metros, com motor Yamaha de $15 \mathrm{Hp}$, disponibilizado pela SABESP, possibilitou navegar pelo reservatório de Biritiba-Mirim (SP), realizando o reconhecimento da área de estudo, amostragens, determinações analíticas "in situ", imagens fotográficas da área protegida por mata ciliar e área antrópica agrícola (Figuras: 18 a 22), identificando também fontes potenciais de contaminação com atividades agrícolas, que fazem uso de agroquímicos. A identificação destas fontes auxiliou na seleção dos pontos de amostragem, além de contribuir para o estudo do uso e ocupação do solo na área.
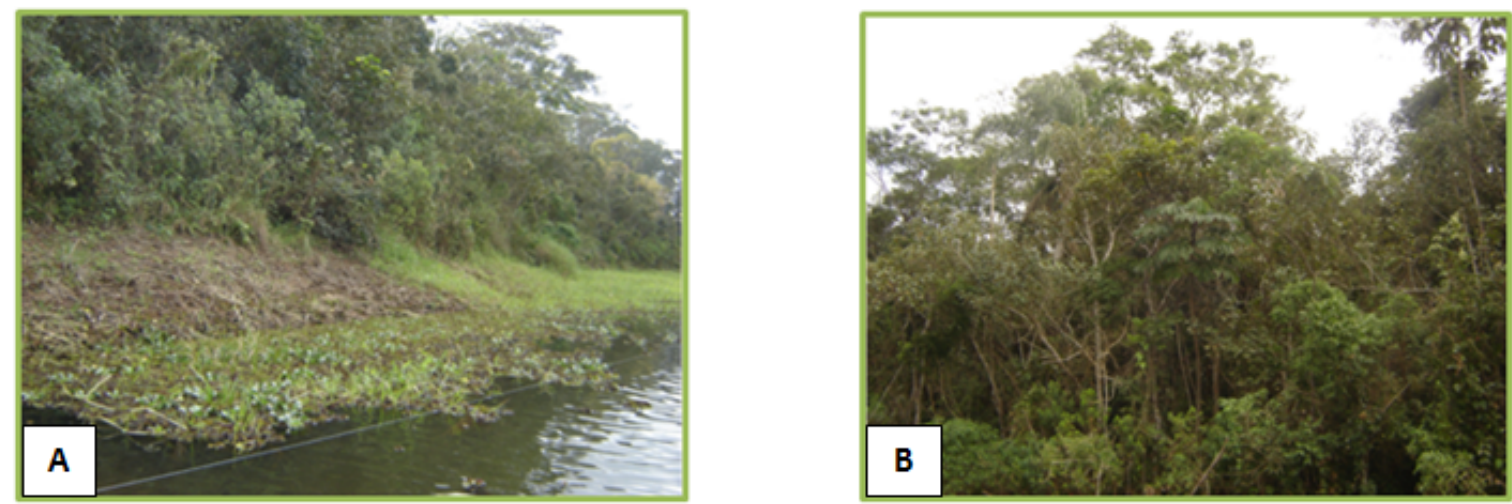

Figura 18A e 18B - Área de amostragem protegida por Mata Ciliar. Fonte: E.Sorrini 


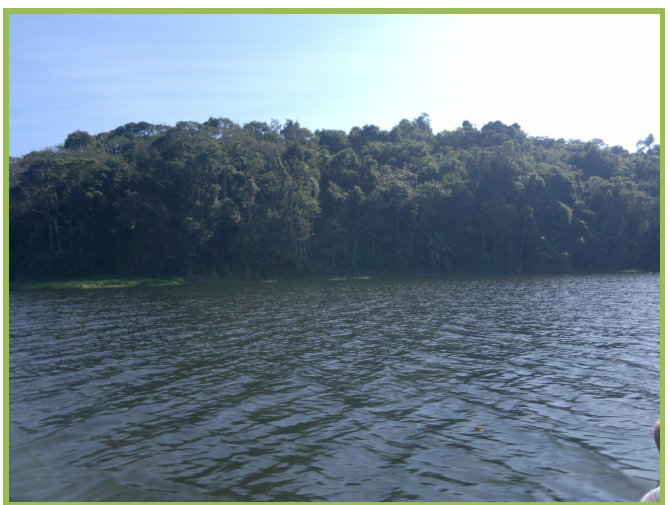

Figura 19 - Área de amostragem protegida por Mata Ciliar. Fonte: E.Sorrini
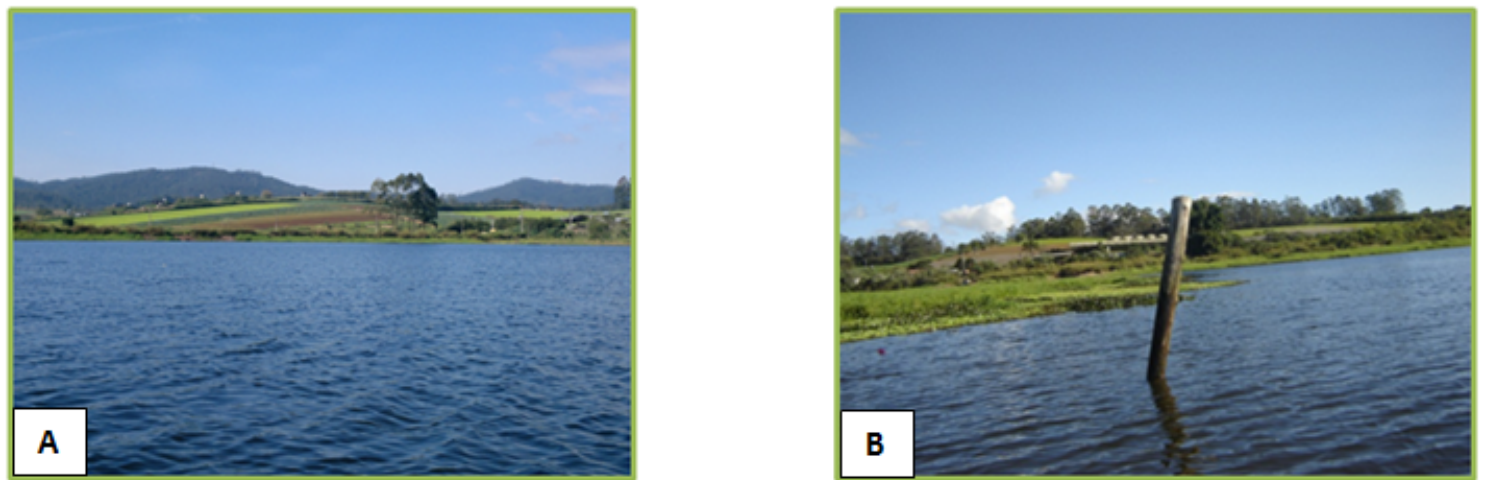

Figura 20A e 20B - Área de amostragem denominada antrópica agrícola não protegida por mata ciliar e próxima da lâmina de água do reservatório. Fonte: E.Sorrini

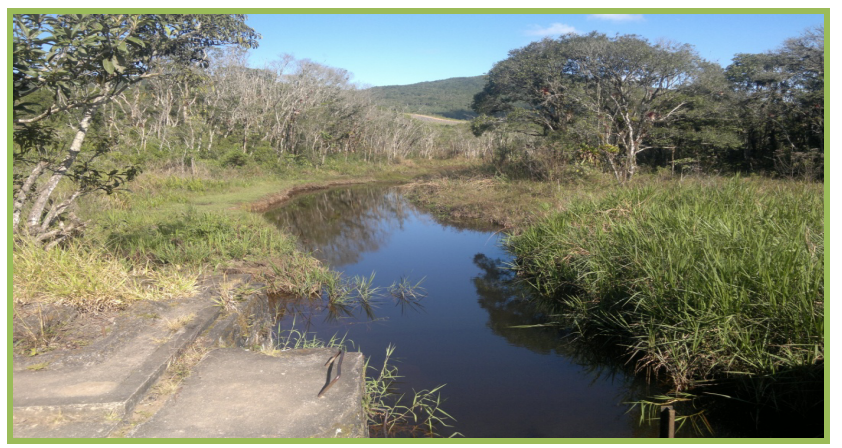

Figura 21 - Área de amostragem na cabeceira do Ribeirão Biritiba-Mirim, ponto referência e de recarga do reservatório. Fonte: E.Sorrini

Após a seleção das três áreas de estudo, a primeira protegida por mata ciliar, a segunda denominada antrópica agrícola e a terceira definida aqui nesta dissertação como o ponto denominado de referência, também foi realizada a caracterização do fragmento de mata ciliar, que está inserida em Área de Preservação Permanente - APP, delimitada em trechos de 0 a 30 metros e de 70 a 
100 metros, conforme mapa de desapropriação do entorno do reservatório de Biritiba-Mirim (SP) (Figura 14).

Após a caracterização fitofisionômica do fragmento de mata ciliar, foram realizadas medidas de distâncias de 50 metros entre um ponto de amostragem e outro dentro do reservatório de Biritiba-Mirim (SP), auxiliado por um sistema topofil de origem francesa denominado "topochain", onde foram concretizadas as marcações georreferenciadas e físicas desses pontos, com auxílio de um GPS marca GARMIN, modelo 12XL e bóias plásticas vermelhas com poita, respectivamente (Figuras 22A, 22B, 23, 24 e 25). Na medida em que as marcações eram realizadas, as amostras de água e sedimentos de fundo também eram coletadas, com o auxílio de um amostrador Kajak-Birkehust modificado pelo orientador desta dissertação (Figuras 26, 27, 28 e 29). As determinações "in situ" dos parâmetros físicos e químicos da água, foram realizadas com auxílio de uma Sonda Multiparâmetro Modelo YSI 6820 V2 (Figuras 30A e 30B), que utiliza sensores corrigidos e calibrados e com tecnologia aprovada pelo USEPA através do protocolo Environmental Technology Verification Program (ETV). As determinações através da Sonda Multiparâmetro, foram realizadas a uma profundidade de 0,30 m a partir do fundo do reservatório. As cinco alíquotas de água e sedimentos de fundo da área antrópica agrícola sem proteção de mata ciliar, as cinco alíquotas de água e sedimento de fundo da área protegida por mata ciliar (área não antrópica) e as duas alíquotas de água e sedimentos de fundo da área denominada referência, foram amostradas através do amostrador Kajak-Birkehust modificado pelo orientador desta dissertação, sendo a água retirada do perfil acima dos sedimentos de fundo (Figuras 27 e 28). 
Todos procedimentos de amostragens e preservações das amostras foram realizados conforme Guia Nacional de Coleta e Preservação de Amostras: água, sedimento, comunidades aquáticas e efluentes líquidos (CETESB; ANA, 2011).
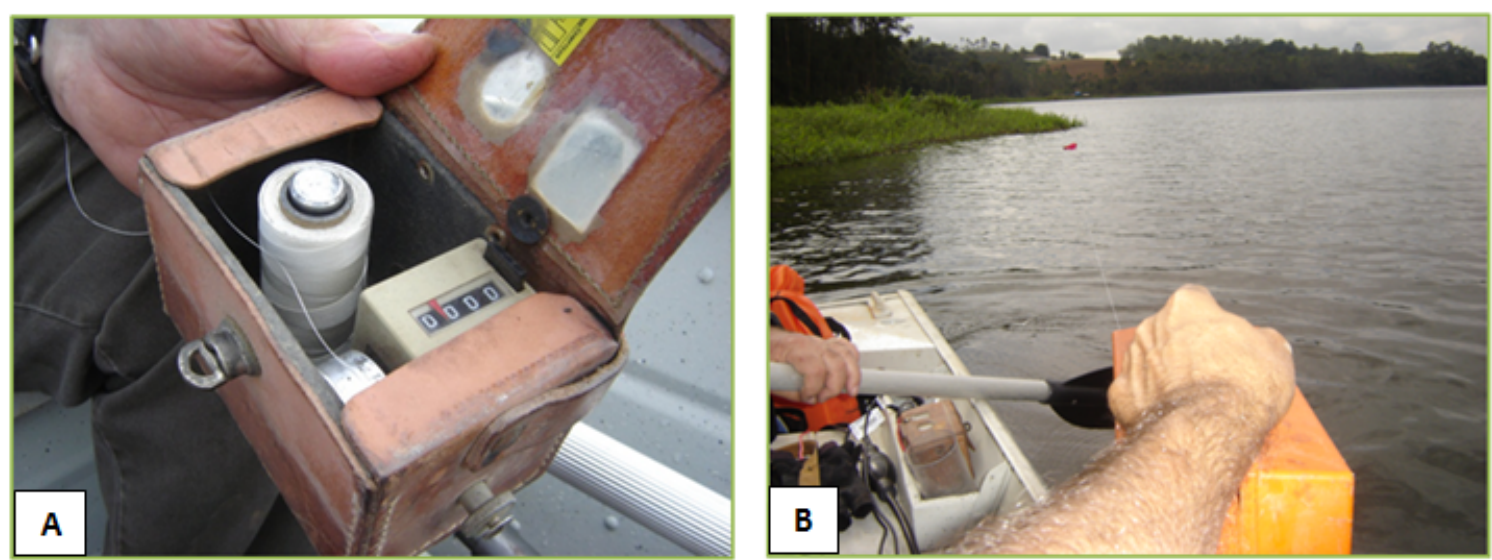

Figura 22A e 22B - A - Marcação dos pontos de amostragens com sistema topofil no Reservatório de Biritiba-Mirim (SP). Fonte: E.Sorrini. B - Marcação dos mesmos pontos com bóias vermelhas. Fonte: J.B.Sígolo.

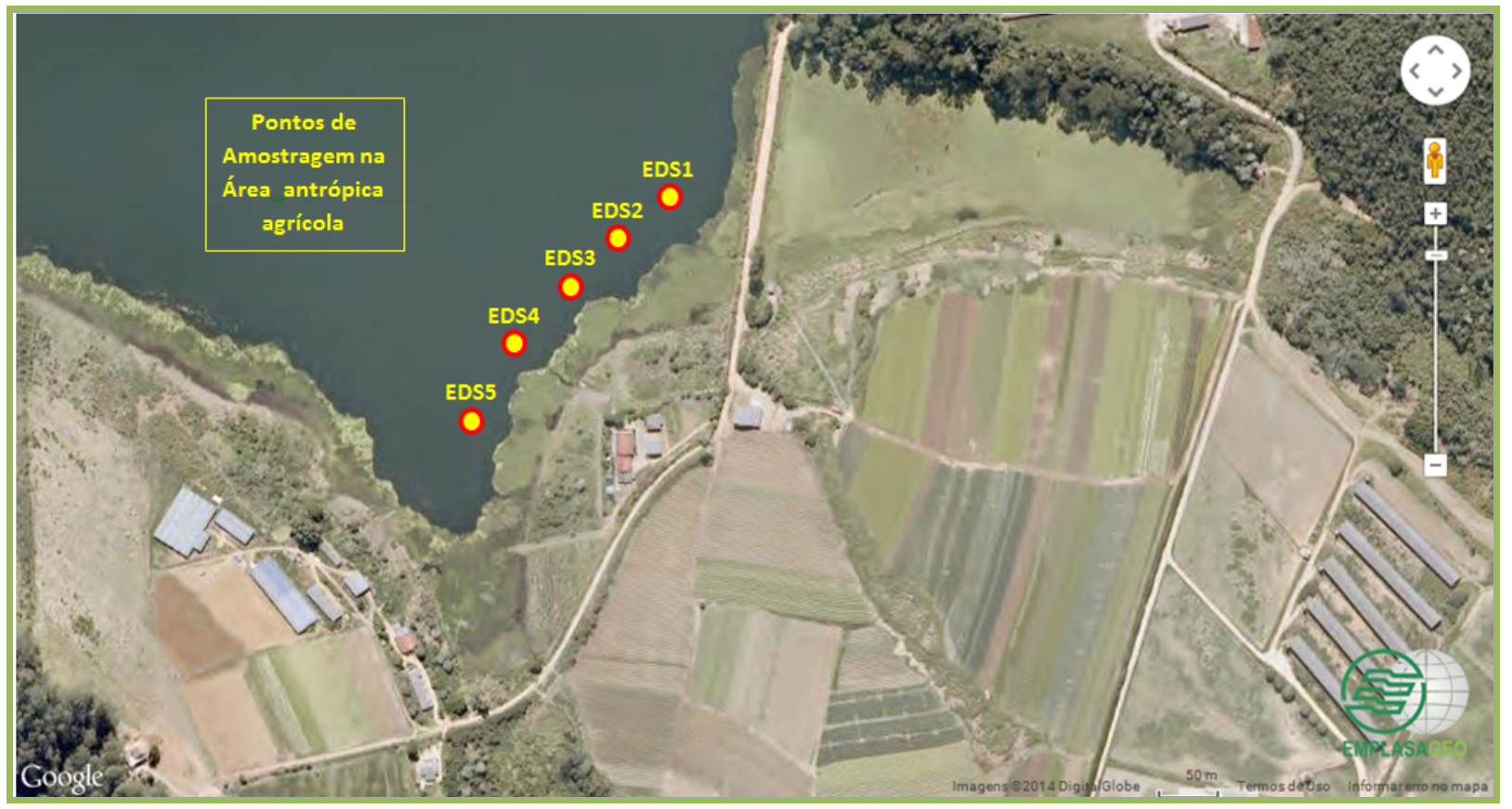

Figura 23 - Imagem do LANDSAT 5 do Reservatório de Biritiba-Mirim (SP), com destaque os pontos de amostragens na área com atividade agrícola (Fonte: MAPEIA, 2014). 


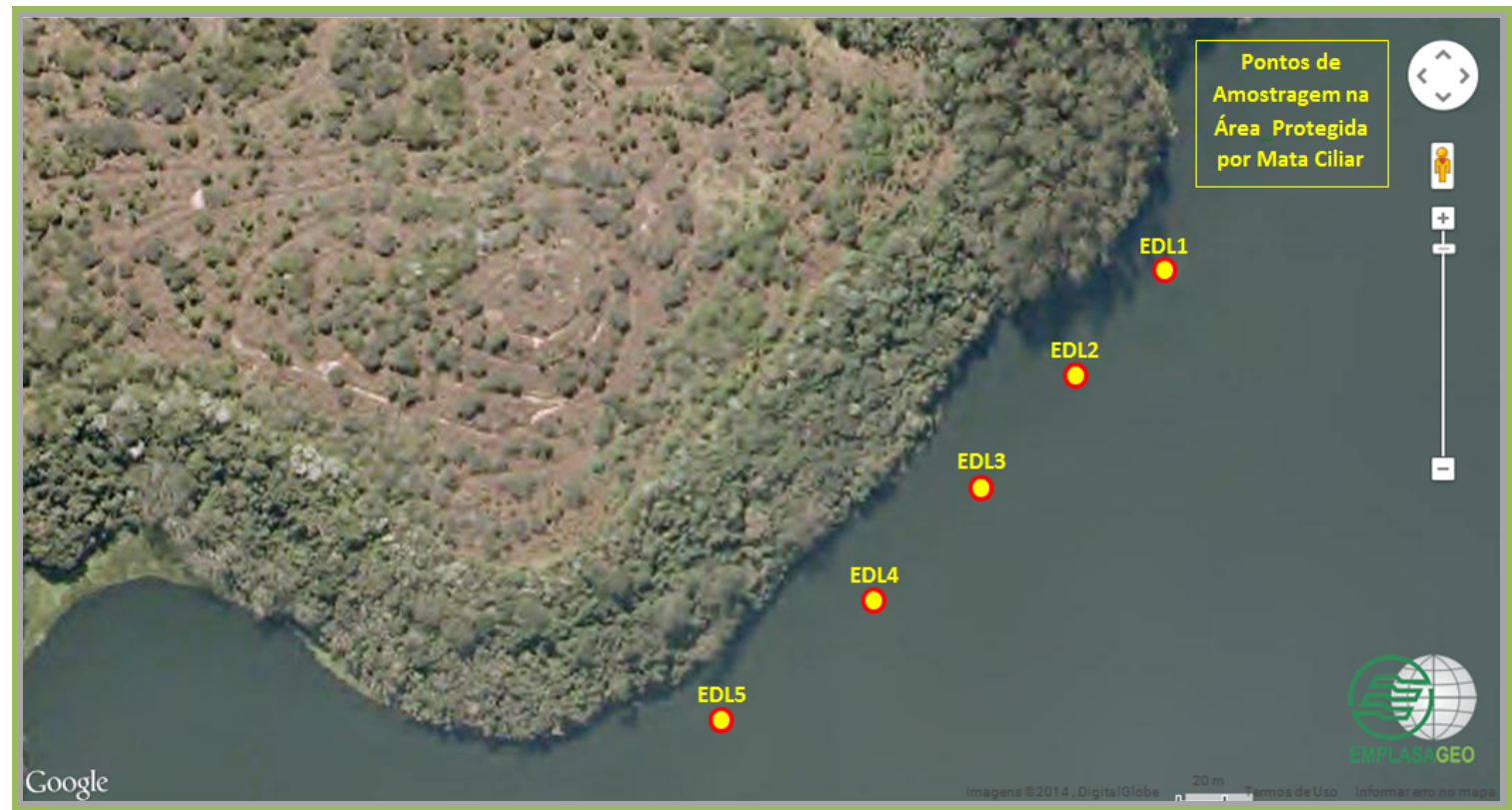

Figura 24 - Imagem do LANDSAT 5 do Reservatório de Biritiba-Mirim (SP), com destaque os pontos de amostragens da área protegida por mata ciliar (Fonte: MAPEIA, 2014).

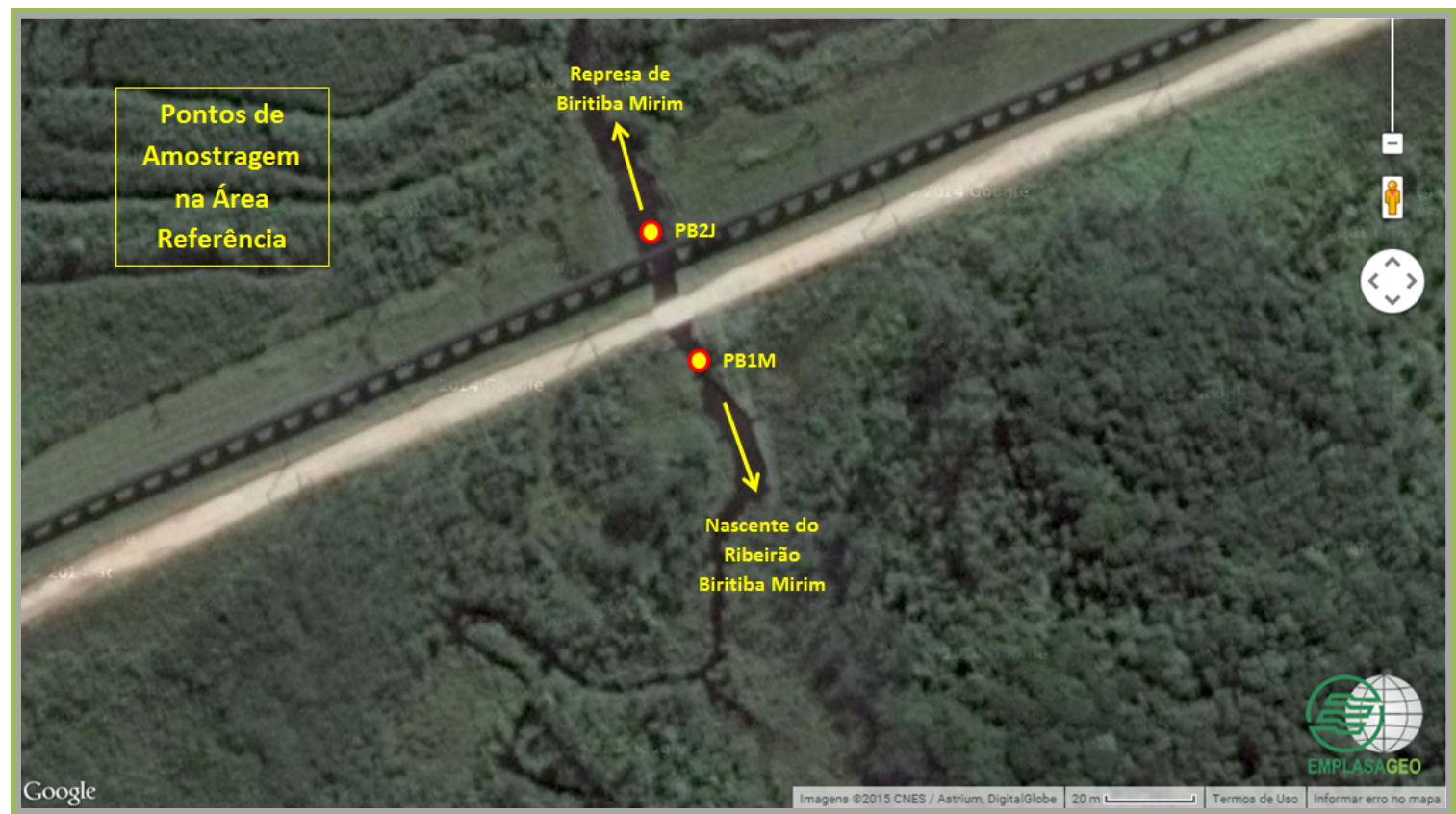

Figura 25 - Imagem do LANDSAT 5 do Ribeirão Biritiba-Mirim (SP), com destaque os pontos de amostragens considerados de referência (Fonte: MAPEIA, 2014).

As amostras de água e sedimentos de fundo foram acondicionadas em recipiente térmico com gelo a uma temperatura próxima a $4{ }^{\circ} \mathrm{C}$, sendo o sedimento embalado em saco plástico inerte sem preservante e com remoção de bolhas de ar, e as amostras de água em tubo plástico de $50 \mathrm{~mL}$, preservada com ácido clorídrico à concentração de $0,1 \%$ para os parâmetros catíônicos e sem preservação, para os 
parâmetros aniônicos, conforme guia nacional de coleta e preservação de amostras:

água, sedimento, comunidades aquáticas e efluentes líquidos (CETESB; ANA, 2011).

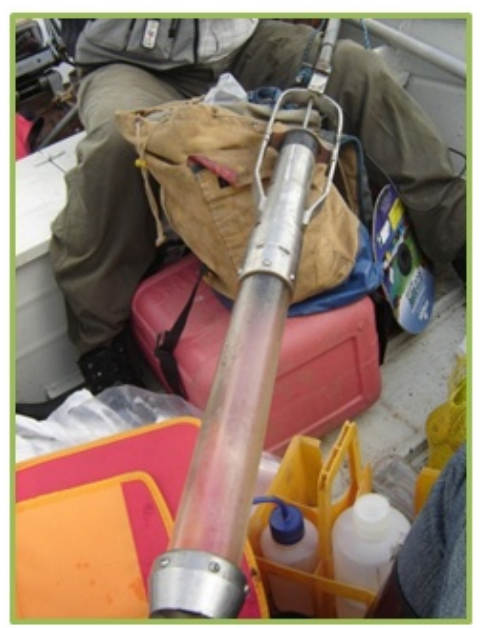

Figura 26 - Tubo coletor Kajak-Birkehust modificado, armado para amostragem de água e sedimentos de fundo. Fonte: E.Sorrini

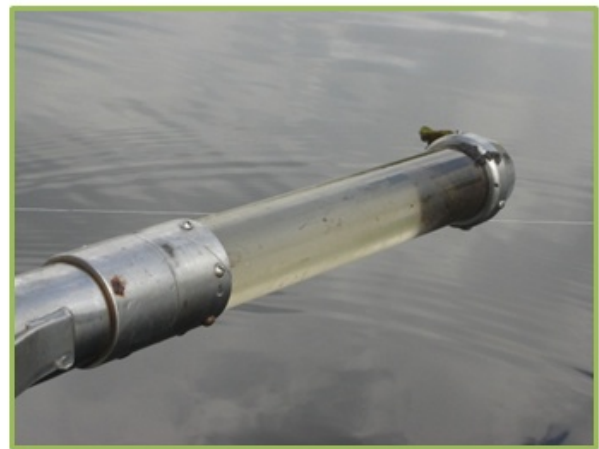

Figura 27 - Tubo coletor Kajak-Birkehust modificado, com água e sedimentos de fundo, retirado de um dos pontos de amostragem. Fonte: E.Sorrini

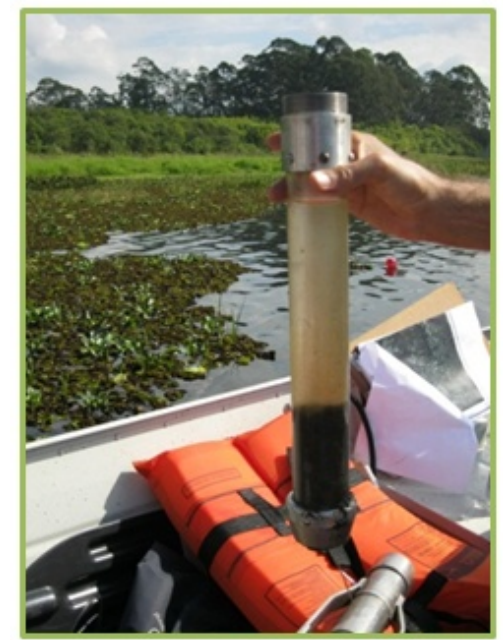

Figura 28 - Tubo coletor Kajak-Birkehust modificado, com água e sedimentos de fundo, retirado de um dos pontos de amostragem. Fonte: J.B.Sígolo 


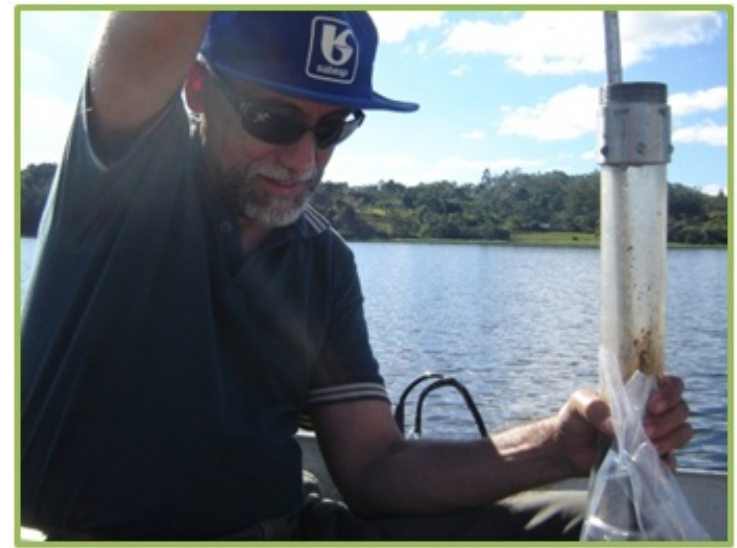

Figura 29 - Procedimento de retirada dos sedimentos de fundo do tubo coletor. Fonte: J.B.Sígolo
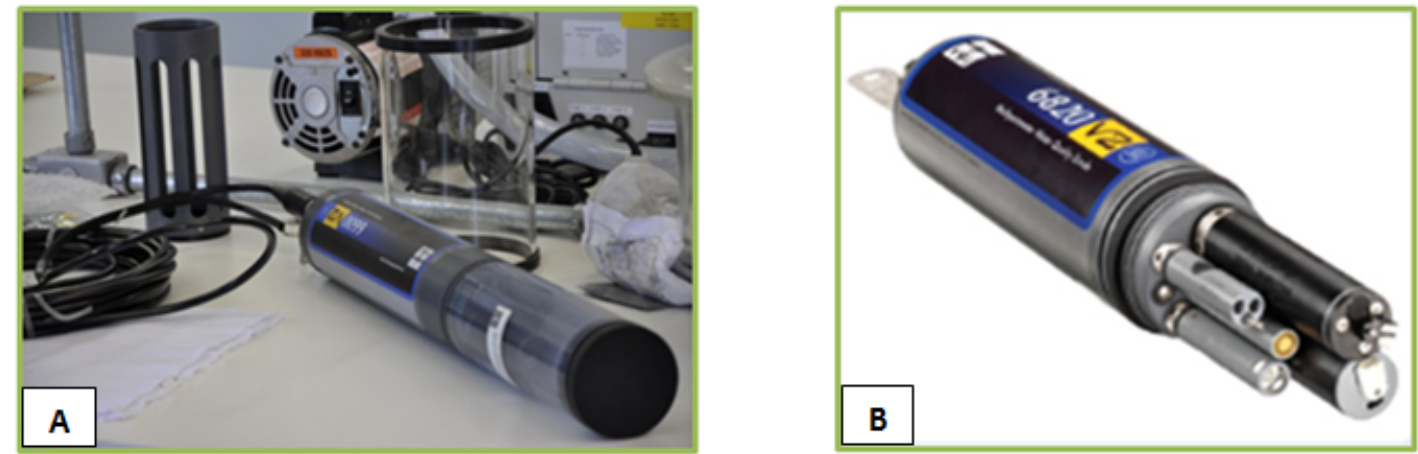

Figura 30A e 30B - A - Imagens da Sonda Multiparâmetro Modelo YSI 6820 V2, para determinação de parâmetros "in situ" no Reservatório de Biritiba-Mirim (SP) - B - Imagem da mesma sonda, destacando os eletrodos dos parâmetros analisados - Fonte: http://www.clean.com.br/

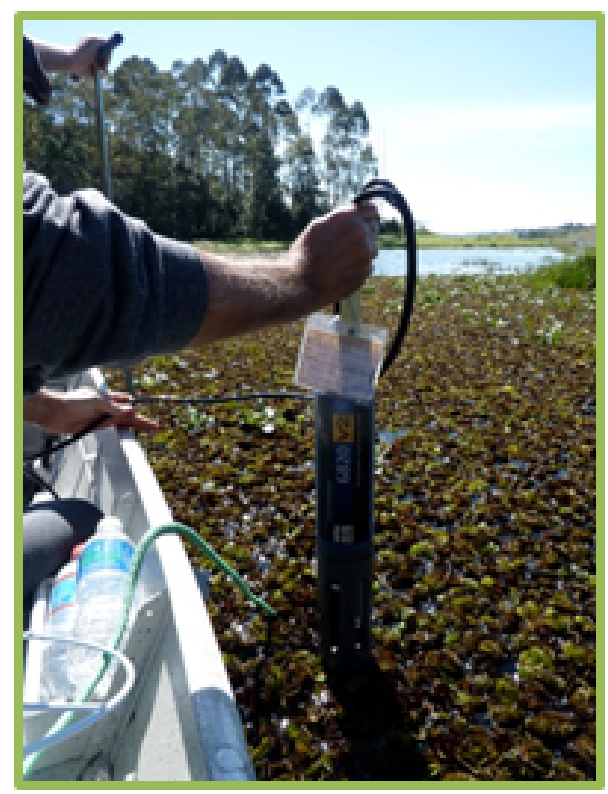

Figura 31 - Determinação de parâmetros "in situ" através da Sonda Multiparâmetro no Reservatório de Biritiba-Mirim (SP) - Fonte: J.B.Sígolo 


\subsubsection{Determinação "in situ" de parâmetros físico-químicos da água}

Durante a campanha de amostragem, foram determinados "in situ" com auxílio de uma sonda modelo YSI 6820 V2 (Figura 31) equipada com sensores corrigidos e calibrados e com tecnologia aprovada pelo USEPA através do protocolo Environmental Technology Verification Program (ETV), os seguintes parâmetros físico-químicos: Potencial Hidrogeniônico $(\mathrm{pH})$, Condutividade Elétrica (CE) já corrigidos para $\mu \mathrm{S} / \mathrm{cm}$, Oxigênio Dissolvido (OD), Potencial de Oxirredução (ORP), Temperatura $\left(\mathrm{T}^{\circ} \mathrm{C}\right)$ e Turbidez (NTU). As determinações dos 12 pontos foram realizadas em dias distintos.

\subsection{Trabalhos de Laboratório}

\subsubsection{Análise química dos sedimentos de fundo}

As amostras de sedimentos de fundo coletadas foram encaminhadas para determinações analíticas no laboratório de caracterização tecnológica (LCT) da Escola Politécnica da Universidade de São Paulo. Esse é laboratório credenciado, certificado e acreditado por diversos órgãos de controle de qualidade e possui procedimentos de análise bastante conhecidos no meio científico e mesmo privado. Nele foram realizadas as determinações de diversos elementos químicos totais (envolvendo elementos potencialmente tóxicos) contidos nos sedimentos de fundo coletados. Os teores obtidos a partir desse laboratório como resultados são apresentados na forma de análises sem padrões (standardless), dos elementos químicos detectados, de flúor a urânio, em espectrômetro por fluorescência de raios X Axios Advanced, marca PANalytical. Perda ao fogo (PF) efetuada a $1.050^{\circ} \mathrm{C}$ por 1h. Detalhamento desse procedimento pode ser obtido na própria página do referido laboratório. 


\subsubsection{Análise química da água}

As alíquotas de água amostradas e preservadas foram encaminhadas para o laboratório de Controle Sanitário da SABESP, acreditado pela NBR ISO/IEC 17025:2005, onde foram realizadas as análises e determinações dos seguintes elementos químicos: Prata (Ag), Alumínio (Al), Arsênio (As), Bário (Ba), Cálcio (Ca), Cádmio (Cd), Cromo (Cr), Cobre (Cu), Ferro (Fe), Magnésio (Mg), Manganês (Mn), Sódio (Na), Níquel (Ni), Chumbo (Pb), Antimônio (Sb), Selênio (Se), Zinco (Zn), Fósforo (P) e Cloreto (Cl-).

A determinação de metais foi realizada segundo método ICP OES/SMEWW 3120 B (Figuras 32A, 32B, 32C, 32D e 33). A determinação de ânions foi realizada, para o parâmetro fósforo, segundo método - SMEWW - 4500-P-E (método do ácido ascórbico) (Figuras 34A, 34B, 34C, 34D e 35). Para o parâmetro cloreto, segundo método - SMEWW - 4500-Cl-B (método argentométrico). Todos os métodos descritos foram realizados segundo o Standard Methods for the Examination of Water and Wastewater APHA (2012). 

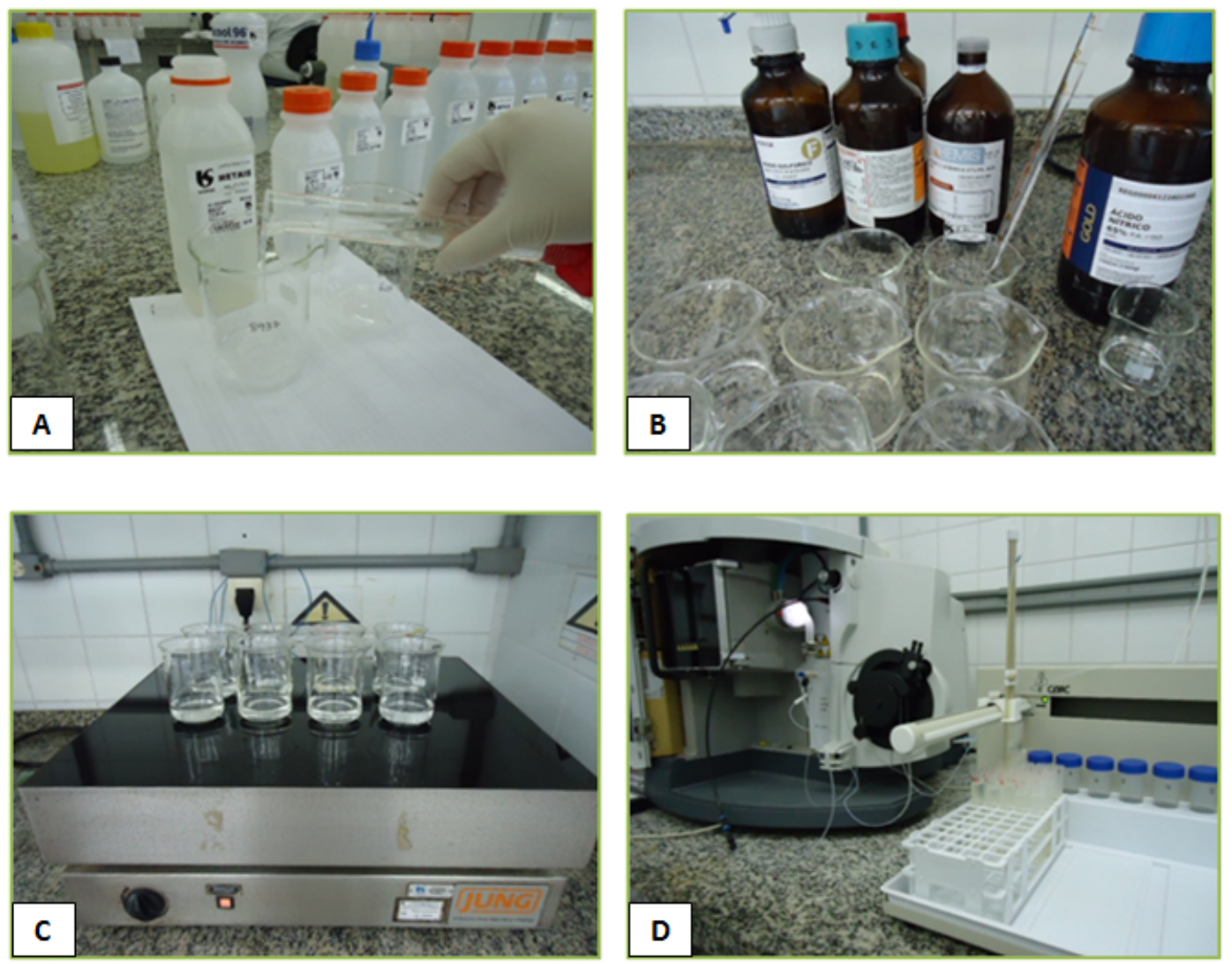

Figura 32A, 32B, 32C e 32D - Procedimento para digestão e leitura das amostras ambientais para determinação de metais (A - Volume com $50 \mathrm{~mL}$ de amostra, B - Acidificação com ácido nítrico, C Digestão e D - Leitura do elemento químico) - Fonte: SABESP

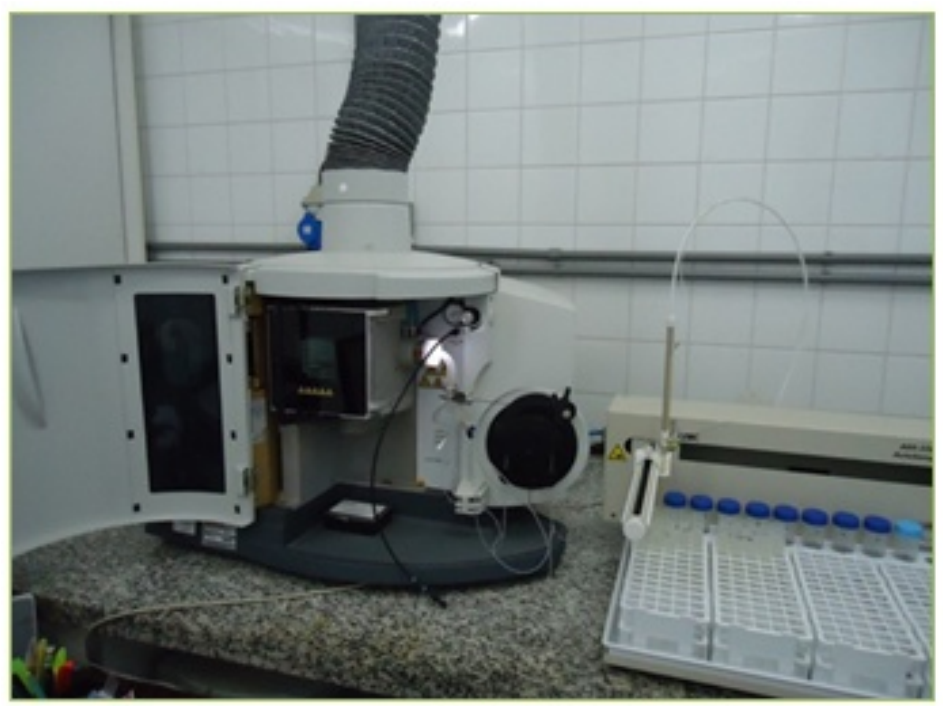

Figura 33 - Equipamento ICP OES utilizado para leitura de metais - Fonte: SABESP 

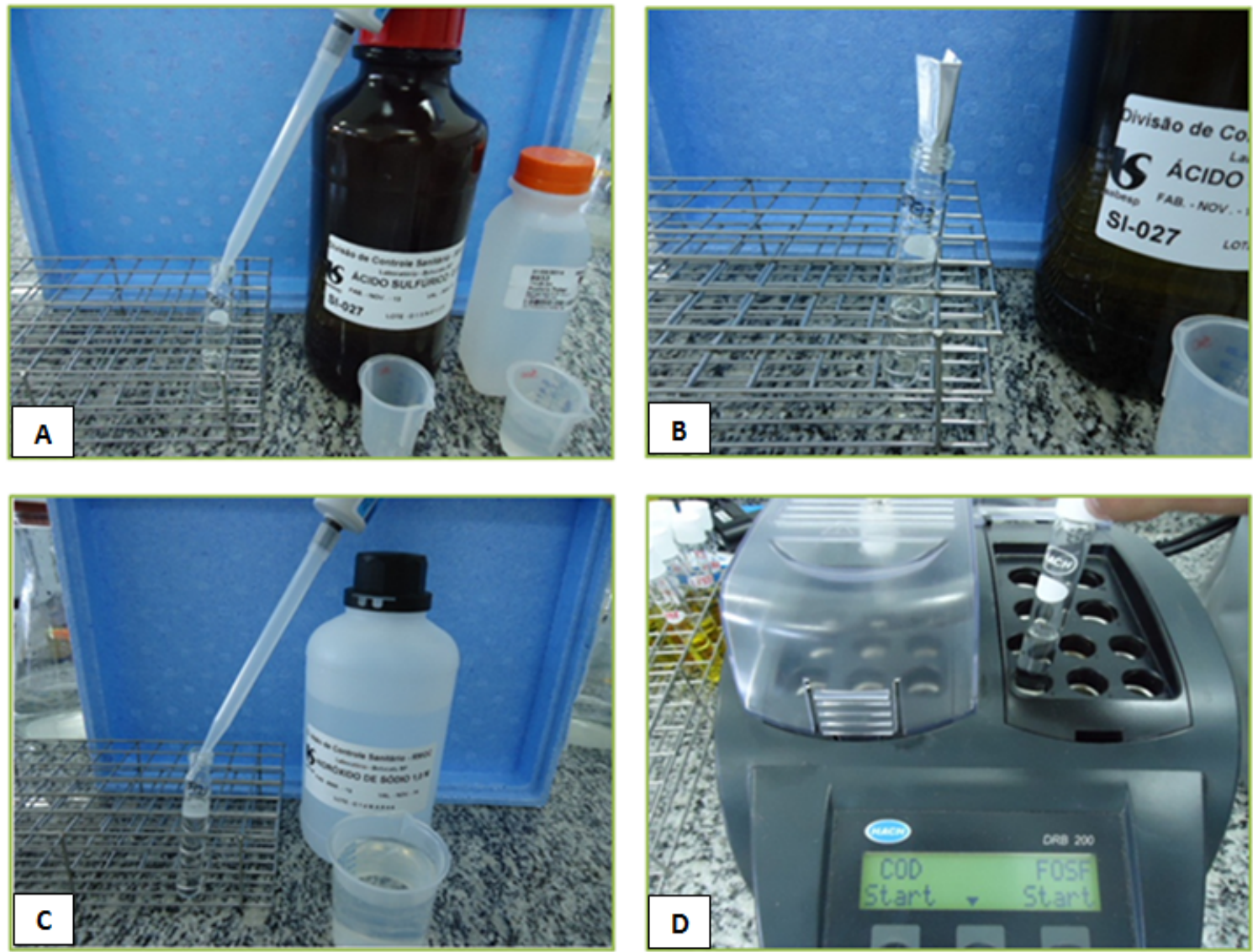

Figura 34A, 34B, 34C e 34D - Procedimento para digestão e leitura das amostras ambientais para determinação de fósforo total (A-Volume com $5 \mathrm{~mL}$ de amostra, B-Acidificação com ácido hidrolizável, C-Adição de $2 \mathrm{~mL}$ de Hidróxido de sódio e D-Leitura do elemento químico). Fonte: SABESP

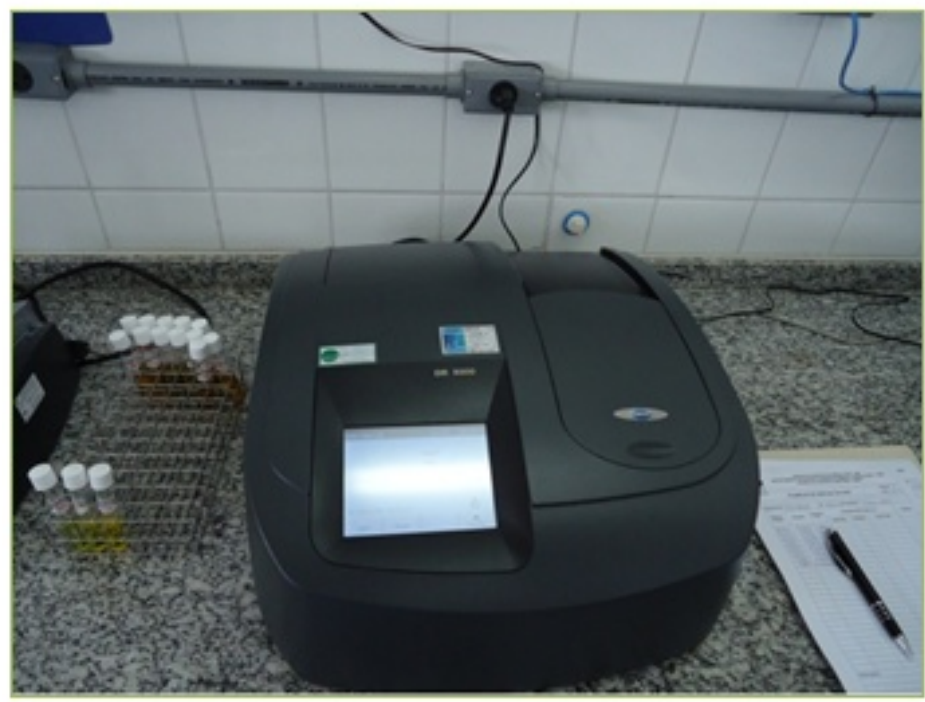

Figura 35 - Equipamento DR5000 utilizado para leitura de fósforo total - Fonte: SABESP 


\section{RESULTADOS}

\subsection{Apresentação dos resultados do compartimento água}

Os resultados dos parâmetros físico-químicos determinados "in situ" com auxílio de uma sonda Multiparâmetro modelo YSI 6820 V2, Potencial Hidrogeniônico $(\mathrm{pH})$, Condutividade Elétrica $(\mathrm{CE})$ já corrigidos para $\mu \mathrm{S} / \mathrm{cm}$, Oxigênio Dissolvido (OD), Potencial de Oxirredução (ORP), Temperatura $\left(\mathrm{T}^{\circ} \mathrm{C}\right)$ e Turbidez apresentados na tabela 2 (EDS), são referentes à área antrópica agrícola, sem proteção de mata ciliar. Os resultados da tabela 3 (EDL), são referentes à área protegida por mata ciliar, e na tabela 4 (PB1M e PB2J), os resultados são referentes ao local de amostragem utilizados como ponto de referência (próxima a nascente do Ribeirão Biritiba-Mirim). 
Tabela 2 - Resultados dos parâmetros físico-químicos determinados "in situ" pela sonda multiparâmetro para o Reservatório de Biritiba-Mirim (SP) na área antrópica agrícola (EDS), sem proteção de mata ciliar.

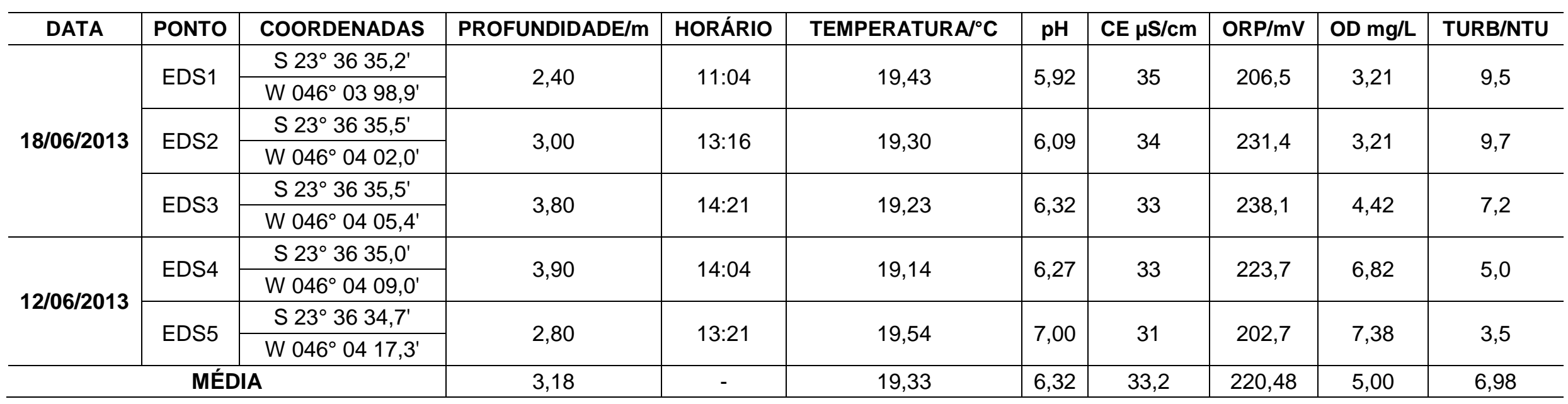

Tabela 3 - Resultados dos parâmetros físico-químicos determinados "in situ" pela sonda multiparâmetro para o Reservatório de Biritiba-Mirim (SP) na área protegida por mata ciliar (EDL)

\begin{tabular}{|c|c|c|c|c|c|c|c|c|c|c|}
\hline DATA & PONTO & COORDENADAS & PROFUNDIDADE/m & HORÁRIO & TEMPERATURA $/{ }^{\circ} \mathrm{C}$ & $\mathrm{pH}$ & $\mathrm{CE} \mu \mathrm{S} / \mathrm{cm}$ & ORP mV & OD mg/L & TURB/NTU \\
\hline \multirow{10}{*}{$11 / 07 / 2013$} & \multirow{2}{*}{ EDL1 } & $\mathrm{S} 23^{\circ} 3624,0^{\prime}$ & \multirow{2}{*}{2,70} & \multirow{2}{*}{$11: 33$} & \multirow{2}{*}{18,76} & \multirow{2}{*}{6,98} & \multirow{2}{*}{31} & \multirow{2}{*}{186,7} & \multirow{2}{*}{6,31} & \multirow{2}{*}{6,3} \\
\hline & & W $046^{\circ} 0487,9$ & & & & & & & & \\
\hline & \multirow{2}{*}{ EDL2 } & $\mathrm{S} 23^{\circ} 3625,7^{\prime}$ & \multirow{2}{*}{2,90} & \multirow{2}{*}{$12: 07$} & \multirow{2}{*}{18,78} & \multirow{2}{*}{6,78} & \multirow{2}{*}{31} & \multirow{2}{*}{258,6} & \multirow{2}{*}{5,97} & \multirow{2}{*}{7,0} \\
\hline & & W $046^{\circ} 0490,4^{\prime}$ & & & & & & & & \\
\hline & \multirow{2}{*}{ EDL3 } & $\mathrm{S} 23^{\circ} 3628,2^{\prime}$ & \multirow{2}{*}{1,90} & \multirow{2}{*}{$12: 48$} & \multirow{2}{*}{18,96} & \multirow{2}{*}{6,76} & \multirow{2}{*}{31} & \multirow{2}{*}{274.3} & \multirow{2}{*}{7,82} & \multirow{2}{*}{7,1} \\
\hline & & W 046º 04 92,8' & & & & & & & & \\
\hline & \multirow{2}{*}{ EDL4 } & $\mathrm{S} 23^{\circ} 3629,1^{\prime}$ & \multirow{2}{*}{2,70} & \multirow{2}{*}{ 13:05 } & \multirow{2}{*}{18,82} & \multirow{2}{*}{6,68} & \multirow{2}{*}{31} & \multirow{2}{*}{268,8} & \multirow{2}{*}{6,54} & \multirow{2}{*}{10,6} \\
\hline & & W $046^{\circ} 0495,1^{\prime}$ & & & & & & & & \\
\hline & \multirow{2}{*}{ EDL5 } & $\mathrm{S} 23^{\circ} 3629,6^{\prime}$ & 310 & $13 \cdot 30$ & 1878 & 666 & 31 & 2617 & 664 & 64 \\
\hline & & W $046^{\circ} 0498,1^{\prime}$ & 3,10 & 13.30 & 18,18 & 0,06 & 31 & $204, I$ & 0,04 & 0,4 \\
\hline & MÉD & & 2,66 & - & 18,82 & 6,77 & 31 & 250,62 & 6,66 & 7,48 \\
\hline
\end{tabular}


Tabela 4 - Resultados dos parâmetros físico-químicos determinados "in situ" pela sonda multiparâmetro na cabeceira do Ribeirão Biritiba-Mirim (SP), valores de referência (PB).

\begin{tabular}{|c|c|c|c|c|c|c|c|c|c|c|}
\hline DATA & PONTO & COORDENADAS & PROFUNDIDADE/m & HORÁRIO & TEMPERATURA $/{ }^{\circ} \mathrm{C}$ & pH & $\mathrm{CE} \mu \mathrm{S} / \mathrm{cm}$ & ORP $\mathrm{mV}$ & OD mg/L & TURB/NTU \\
\hline \multirow{4}{*}{$12 / 07 / 2013$} & \multirow{2}{*}{ PB1M } & S $23^{\circ} 4026,29^{\prime}$ & \multirow{2}{*}{1} & \multirow{2}{*}{$17: 34$} & \multirow{2}{*}{14,67} & \multirow{2}{*}{4,84} & \multirow{2}{*}{16} & \multirow[b]{2}{*}{237,9} & \multirow[b]{2}{*}{7,57} & \multirow{2}{*}{2,2} \\
\hline & & W $046^{\circ} 0453,47^{\prime}$ & & & & & & & & \\
\hline & \multirow{2}{*}{ PB2J } & $S 23^{\circ} 4024,0^{\prime}$ & \multirow{2}{*}{1} & \multirow{2}{*}{$17: 40$} & \multirow{2}{*}{14,69} & \multirow{2}{*}{5,09} & \multirow{2}{*}{17} & \multirow{2}{*}{226,8} & \multirow{2}{*}{7,51} & \multirow{2}{*}{2,5} \\
\hline & & W $046^{\circ} 0452.2^{\prime}$ & & & & & & & & \\
\hline \multicolumn{3}{|c|}{ MÉDIA } & 1 & - & 14,68 & 4,96 & 16,5 & 232,35 & 7,54 & 2,35 \\
\hline
\end{tabular}


Para análise e determinação química da água, as amostras coletadas no local de estudo, foram encaminhadas para o laboratório de química da SABESP, conforme descrito em item anterior.

Foram realizadas análises para os elementos químicos: Ag, Al, As, Ba, Ca, Cd, Cr, Cu, Fe, Mg, Mn, Na, Ni, Pb, Sb, Se, Zn, Cloreto e Fósforo total, as tabelas 5, 6 e 7 exibem somente os resultados que se apresentaram acima dos limites de quantificação dos aparelhos e suas respectivas médias aritméticas.

Tabela 5 - Resultados dos parâmetros químicos da água analisados em laboratório para o Ribeirão Biritiba-Mirim (SP), ponto considerado de referência (PB1M e PB2J).

\begin{tabular}{c|c|c|c|c|c|c|c}
\hline $\begin{array}{r}\text { Elemento Químico } \\
\mathbf{( m g / L )}\end{array}$ & Al & Ca & Fe & Mg & Na & Zn & Fósforo \\
Ponto de Amostragem & 0,352 & 0,750 & 0,537 & 0,350 & 2,120 & 0,138 & 0,440 \\
\hline PB1M & 0,170 & 0,560 & 0,706 & 0,310 & 1,990 & 0,252 & 0,130 \\
\hline PB2J & 0,261 & 0,655 & 0,621 & 0,330 & 2,055 & 0,195 & 0,285 \\
\hline Média &
\end{tabular}

Nota: Estão tabelados apenas os valores que se apresentaram acima dos limites de quantificação do aparelho e suas respectivas médias aritméticas.

Tabela 6 - Resultados dos parâmetros químicos da água analisados em laboratório para o Reservatório de Biritiba-Mirim (SP) na área protegida por mata ciliar (amostras EDL $1,2,3,4,5)$.

\begin{tabular}{c|c|c|c|c|c|c}
\hline $\begin{array}{c}\text { Elemento Químico } \\
(\mathbf{m g} / \mathbf{L})\end{array}$ & EDL1 & EDL2 & EDL3 & EDL4 & EDL5 & Média \\
\hline $\mathbf{A l}$ & 0,099 & 0,110 & 0,106 & 0,082 & 0,123 & 0,104 \\
\hline $\mathbf{C a}$ & 1,460 & 2,160 & 1,190 & 0,820 & 1,530 & 1,432 \\
\hline $\mathbf{F e}$ & 0,202 & 0,206 & 0,176 & 0,176 & 0,200 & 0,192 \\
\hline $\mathbf{M g}$ & 0,470 & 0,760 & 0,410 & 0,300 & 0,530 & 0,494 \\
\hline $\mathbf{N a}$ & 3,650 & 2,260 & 1,410 & 0,810 & 1,930 & 2,012 \\
\hline $\mathbf{Z n}$ & 0,126 & 0,126 & 0,116 & 0,219 & 0,180 & 0,153 \\
\hline Fósforo & 0,020 & 0,030 & 0,030 & 0,040 & 0,030 & 0,030 \\
\hline
\end{tabular}

Nota: Estão tabelados apenas os valores que se apresentaram acima dos limites de quantificação do aparelho e suas respectivas médias aritméticas. 
Tabela 7 - Resultados dos parâmetros químicos da água analisados em laboratório para o Reservatório de Biritiba-Mirim (SP) em área antrópica agrícola (amostras EDS 1,2,3,4,5).

\begin{tabular}{c|c|c|c|c|c|c}
\hline $\begin{array}{c}\text { Elemento Químico } \\
(\mathbf{m g} / \mathbf{L})\end{array}$ & EDS1 & EDS2 & EDS3 & EDS4 & EDS5 & Média \\
\hline $\mathbf{A l}$ & 0,052 & 0,111 & 0,092 & 0,268 & 0,138 & 0,132 \\
\hline $\mathbf{C a}$ & 2,380 & 3,030 & 1,770 & 2,270 & 1,670 & 2,224 \\
\hline $\mathbf{F e}$ & 0,262 & 0,404 & 0,258 & 0,226 & 0,475 & 0,325 \\
\hline $\mathbf{M g}$ & 0,860 & 1,080 & 0,650 & 0,850 & 0,600 & 0,808 \\
\hline $\mathbf{N a}$ & 2,190 & 2,840 & 1,350 & 2,850 & 1,490 & 2,144 \\
\hline $\mathbf{Z n}$ & 0,066 & 0,204 & 0,295 & 0,107 & 0,075 & 0,149 \\
\hline Fósforo & 0,060 & 0,010 & 0,070 & 0,370 & 0,010 & 0,104 \\
\hline
\end{tabular}

Nota: Estão tabelados apenas os valores que se apresentaram acima dos limites de quantificação do aparelho e suas respectivas médias aritméticas.

Tabela 8 - Comparação entre os valores máximos permitidos de elementos químicos em água segundo CONAMA 357/2005 - Classe I.

\begin{tabular}{c|c|c|c|c|c|c|c}
\hline $\begin{array}{c}\text { Elementos } \\
\text { Químicos }\end{array}$ & Al & Ca & Fe & Mg & Na & Zn & Fósforo \\
\hline $\begin{array}{c}\text { Padrão de } \\
\text { Qualidade } \\
\begin{array}{c}\text { Classe I } \\
\text { (mg/L) }\end{array}\end{array}$ & 0,1 & - & 0,3 & - & - & 0,18 & 0,020 \\
\hline
\end{tabular}

5.1.1 Apresentação gráfica dos parâmetros físico-químicos da água realizados pela Sonda Multiparâmetro nos pontos de amostragem denominados EDS 1,2,3,4,5 (Antrópica); EDL 1,2,3,4,5 (Mata Ciliar); PB1M e PB2J (Ponto Referência), com base nas tabelas: 2, 3 e 4, respectivamente.

Gráfico 2 - Potencial Hidrogeniônico Dado Bruto

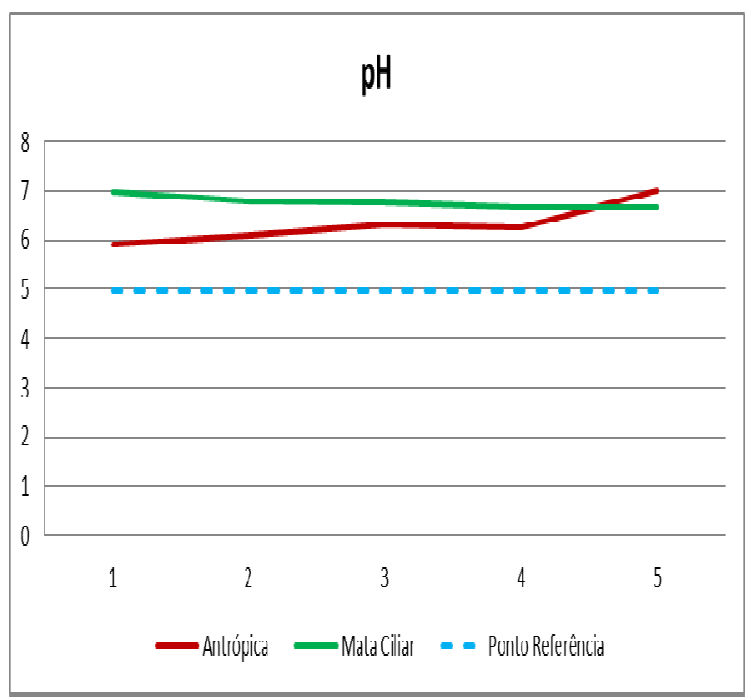

Gráfico 3 - Potencial Hidrogeniônico Média

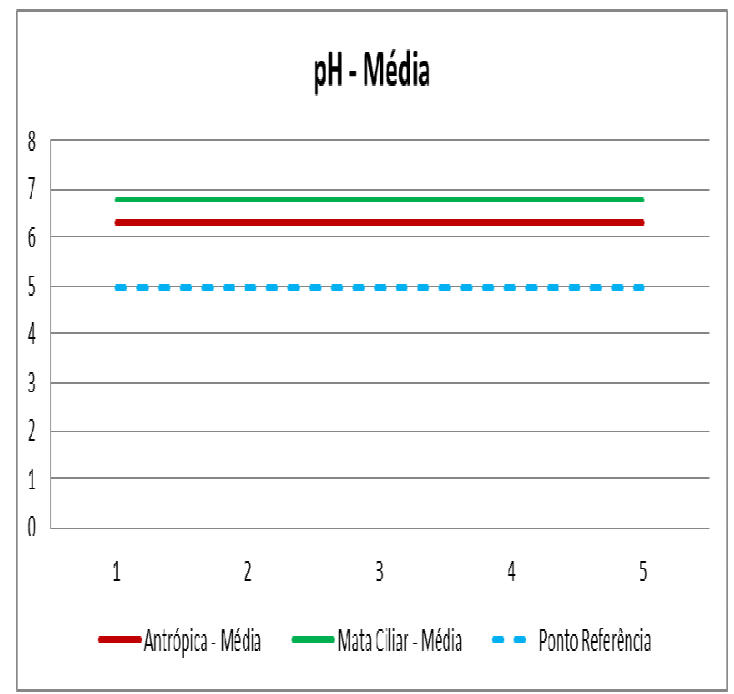


Gráfico 4 - Oxigênio Dissolvido (mg/L) Dado Bruto

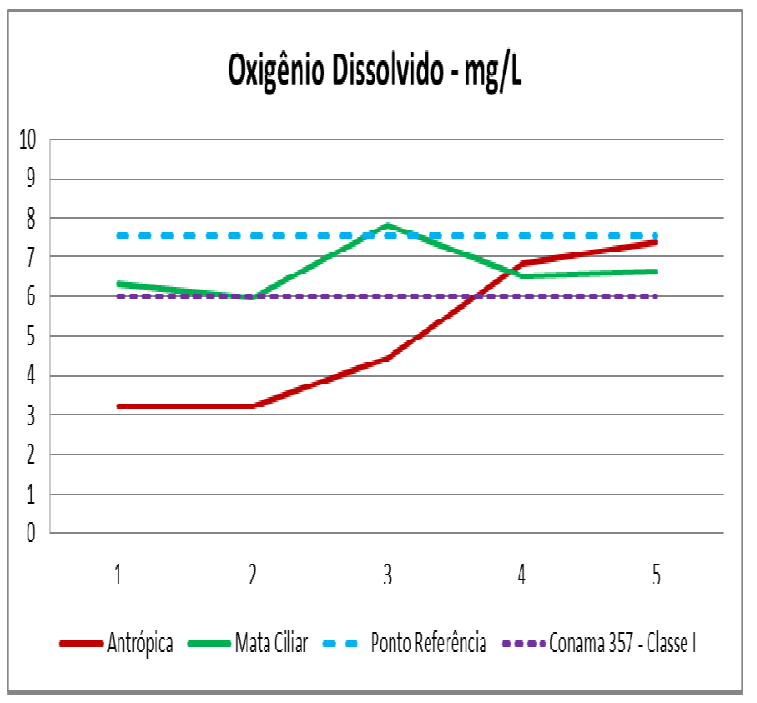

Gráfico 6 - Temperatura $\left({ }^{\circ} \mathrm{C}\right)$ - Dado Bruto

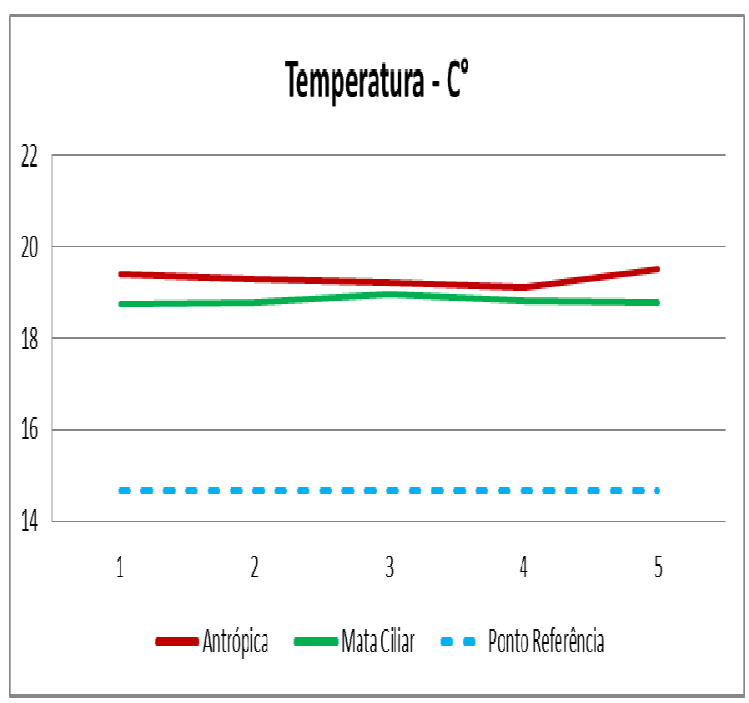

Gráfico 5 - Oxigênio Dissolvido (mg/L) Média

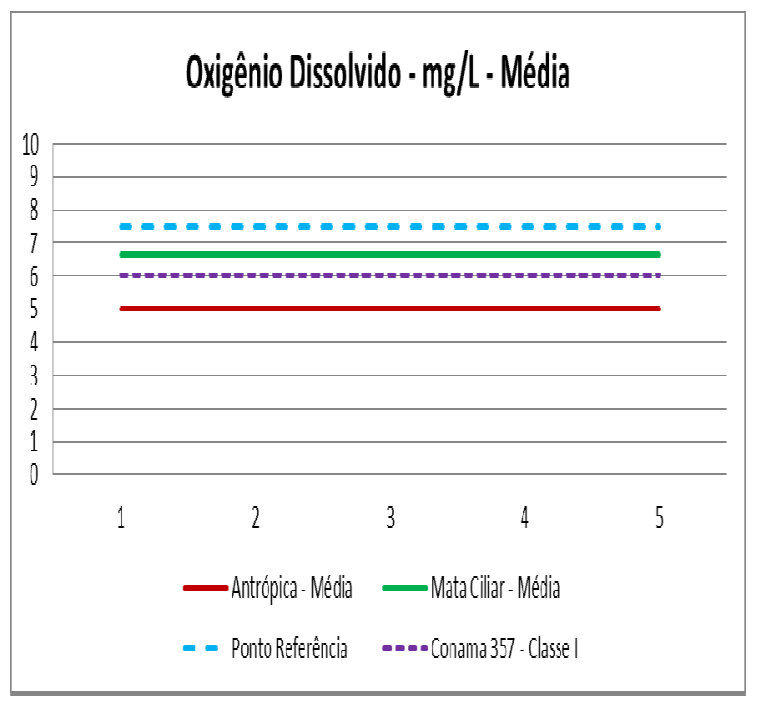

Gráfico 7 - Temperatura $\left({ }^{\circ} \mathrm{C}\right)$ - Média

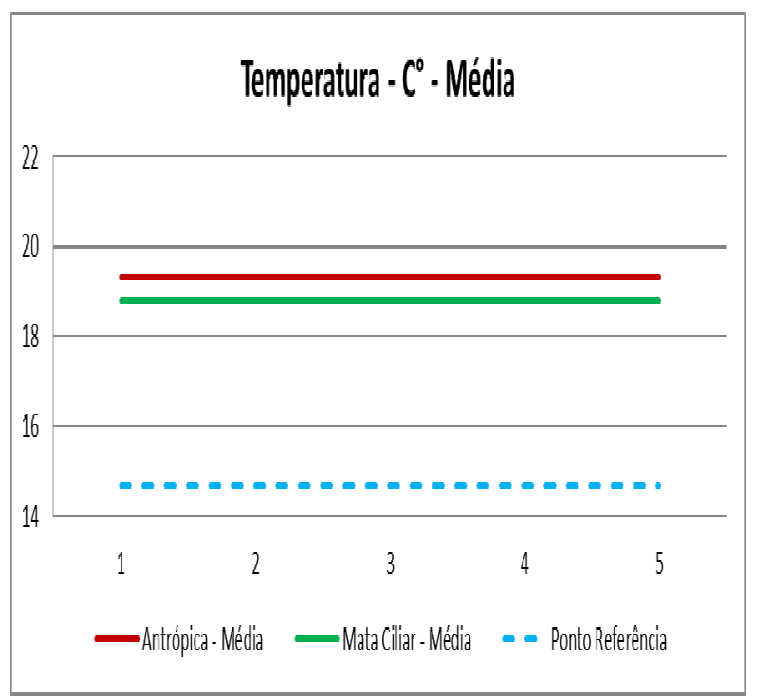


Gráfico 8 - Condutividade $(\mu \mathrm{S} / \mathrm{cm})$ - Dado Bruto

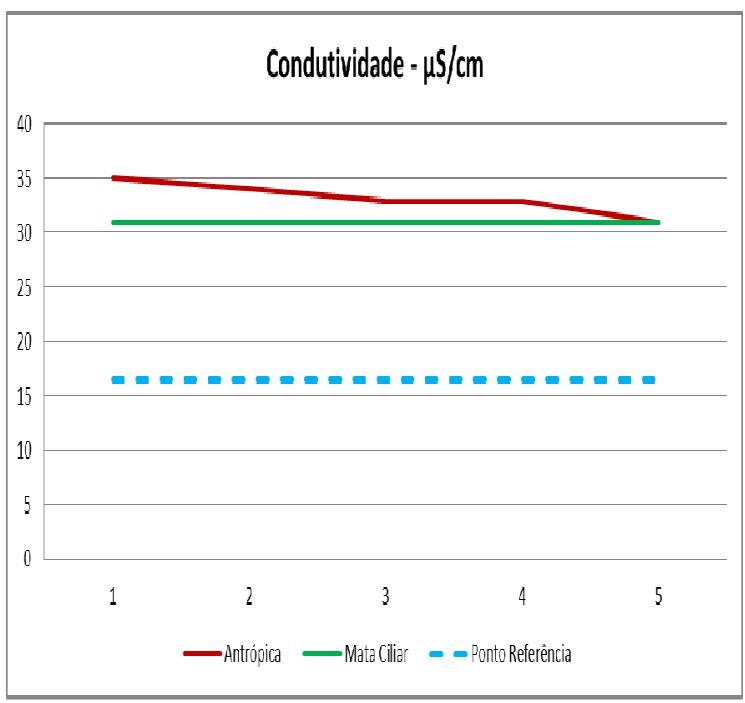

Gráfico 10 - Turbidez (NTU) - Dado Bruto

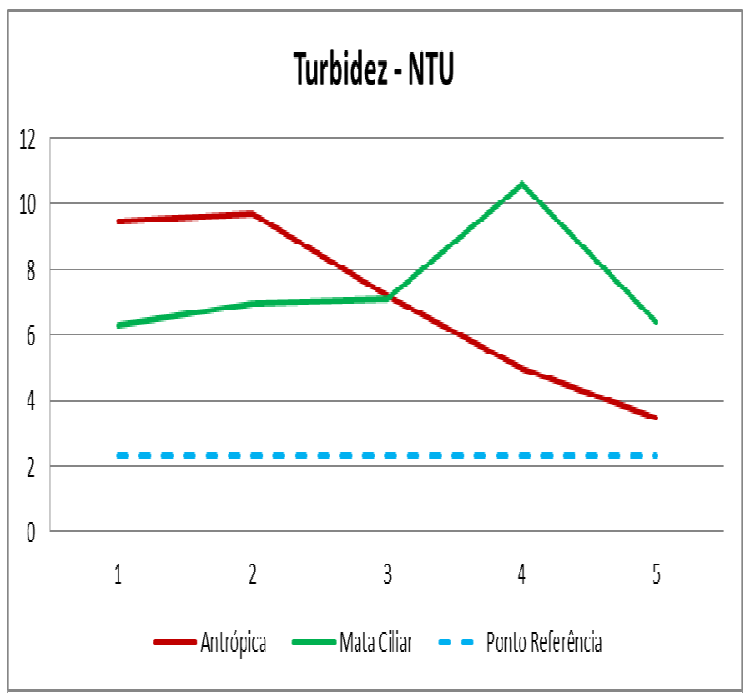

Gráfico 9 - Condutividade ( $\mu \mathrm{S} / \mathrm{cm})$ Média

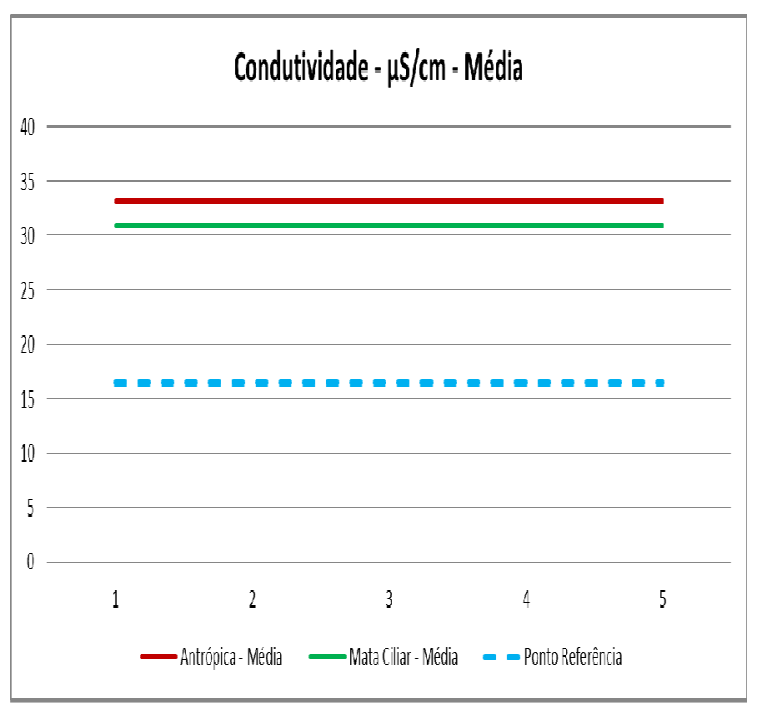

Gráfico 11 - Turbidez (NTU) - Média

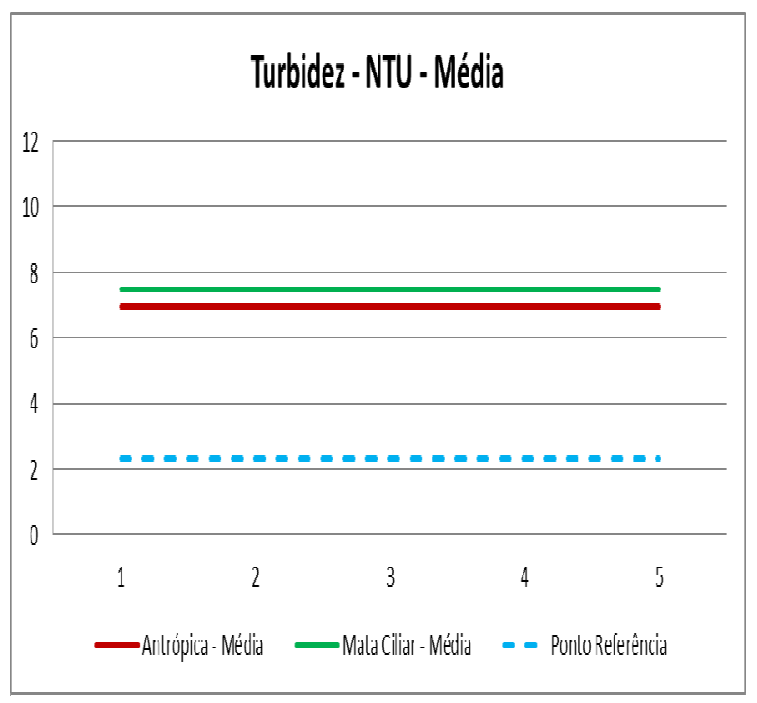


Gráfico 12 - Potencial de Oxirredução $(\mathrm{mV})$ - Dado Bruto

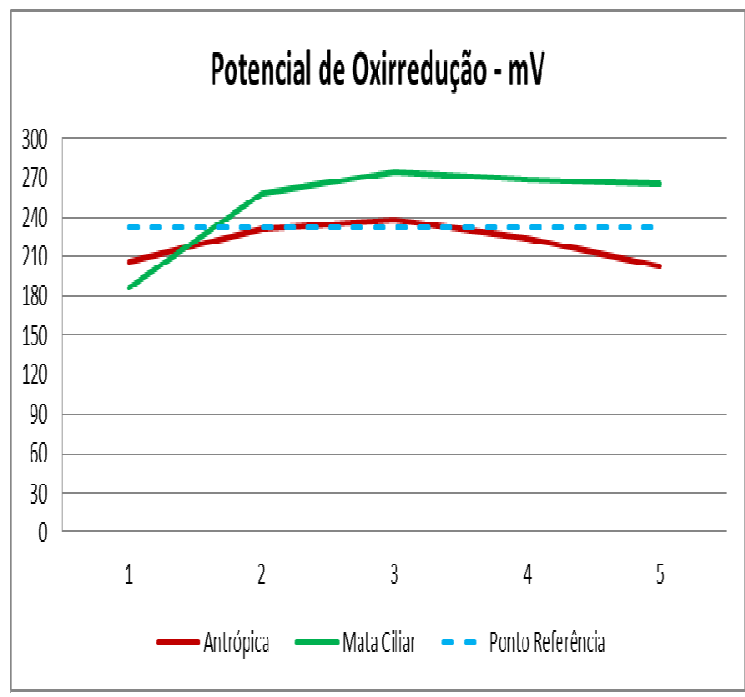

Gráfico 13 - Potencial de Oxirredução $(\mathrm{mV})$ - Média

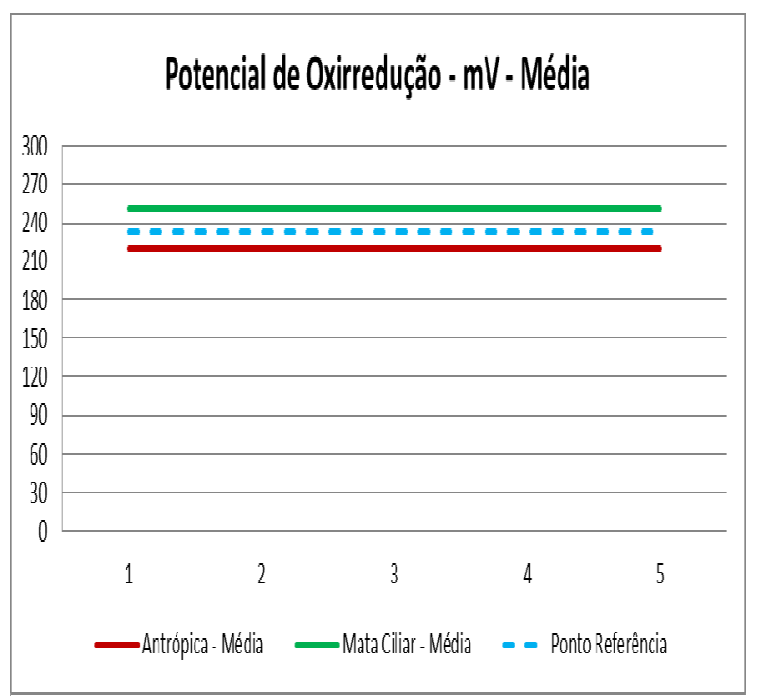

5.1.2 Apresentação gráfica dos resultados dos elementos químicos encontrados na água realizados em laboratório nos pontos de amostragem PB1M e PB2J (Ponto Referência); EDL 1,2,3,4,5 (Mata Ciliar); EDS 1,2,3,4,5 (Antrópica), com base nas tabelas 5, 6 e 7, respectivamente.

Gráfico 14 - Alumínio (mg/L) - Dado Bruto

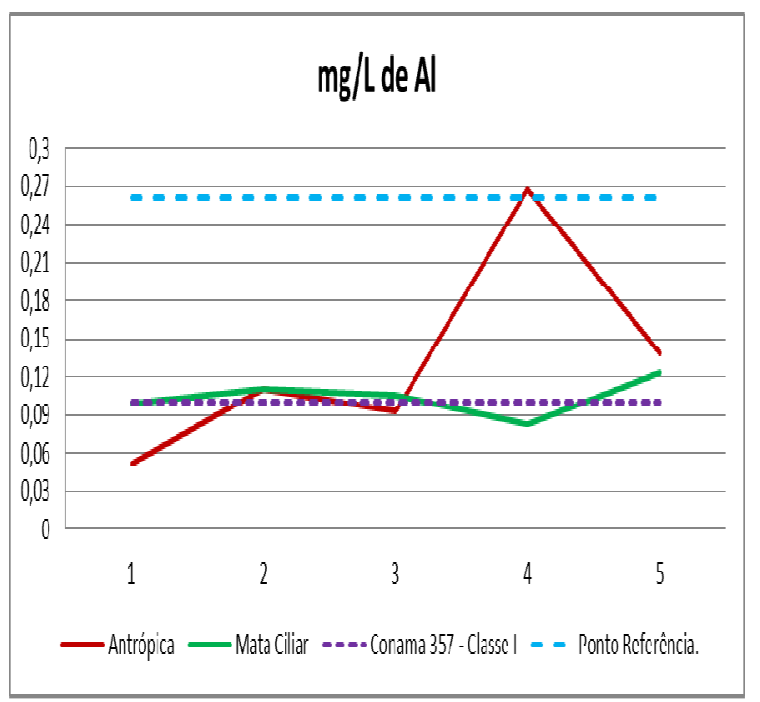

Gráfico 15 - Alumínio (mg/L) - Média

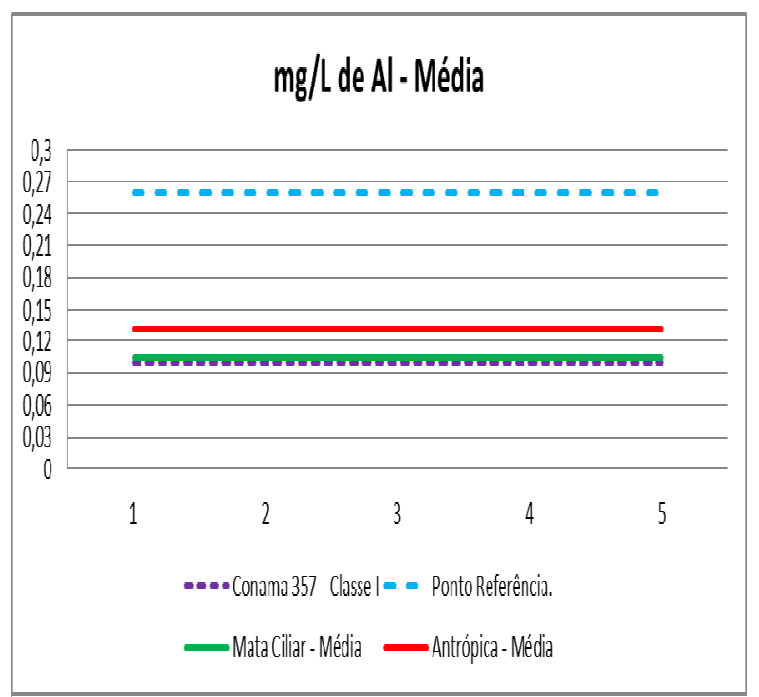


Gráfico 16 - Cálcio (mg/L) - Dado Bruto

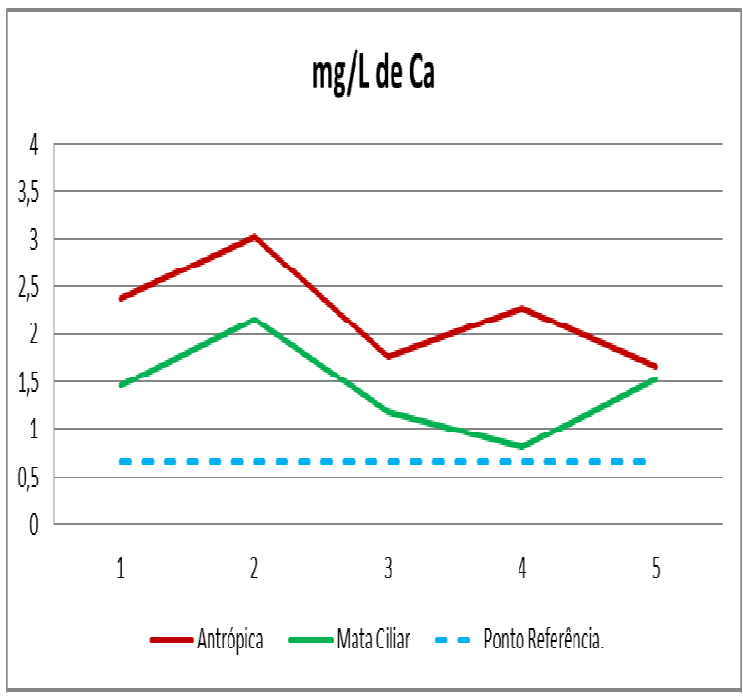

Gráfico 18 - Ferro (mg/L) - Dado Bruto

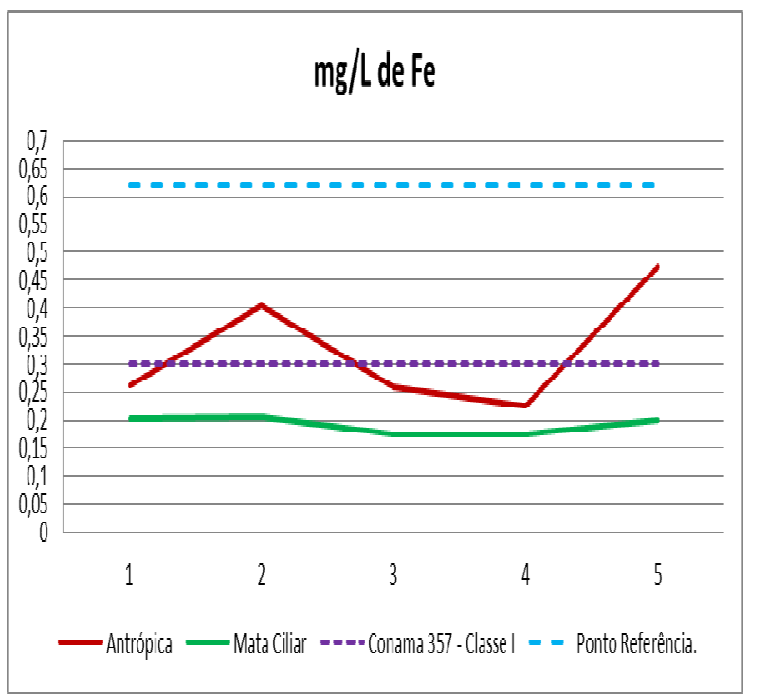

Gráfico 17 - Cálcio (mg/L) - Média

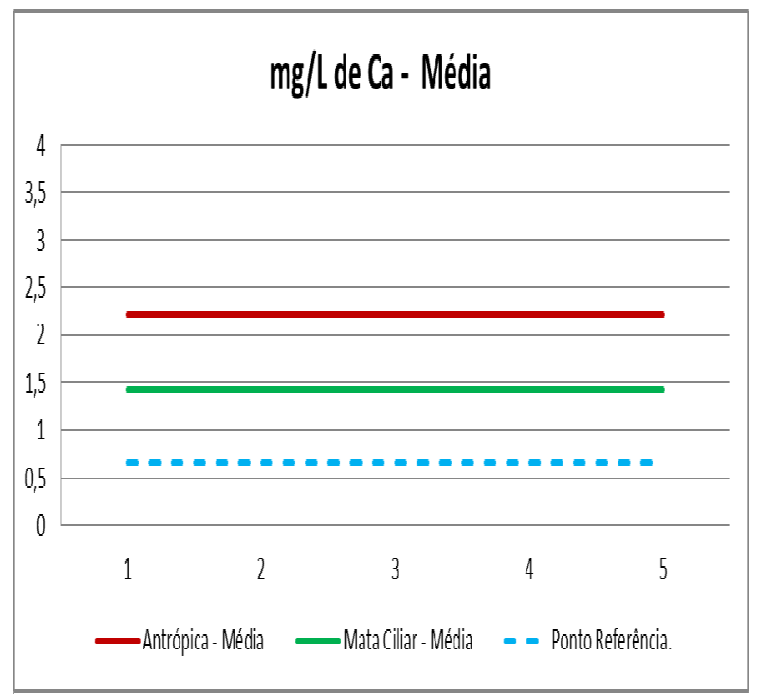

Gráfico 19 - Ferro (mg/L) - Média

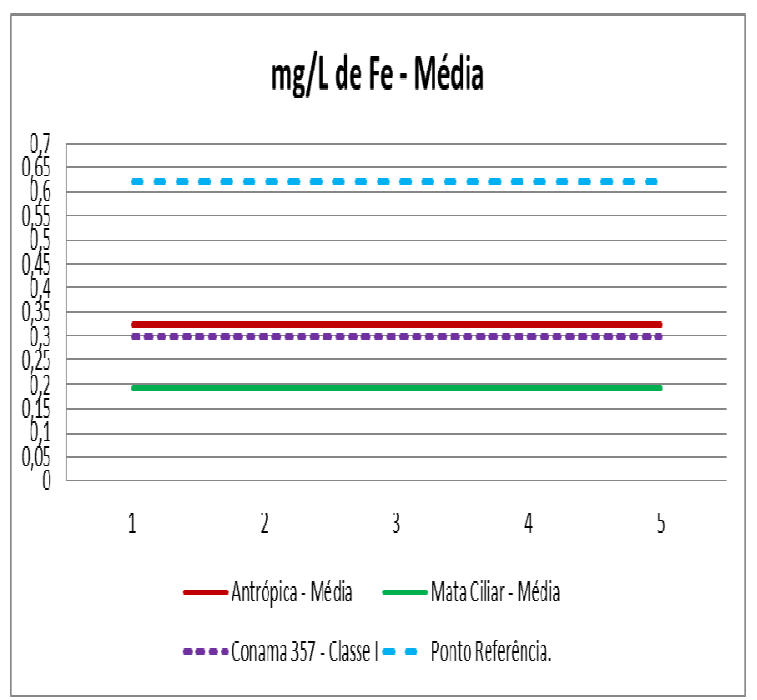


Gráfico 20 - Magnésio (mg/L) - Dado Bruto

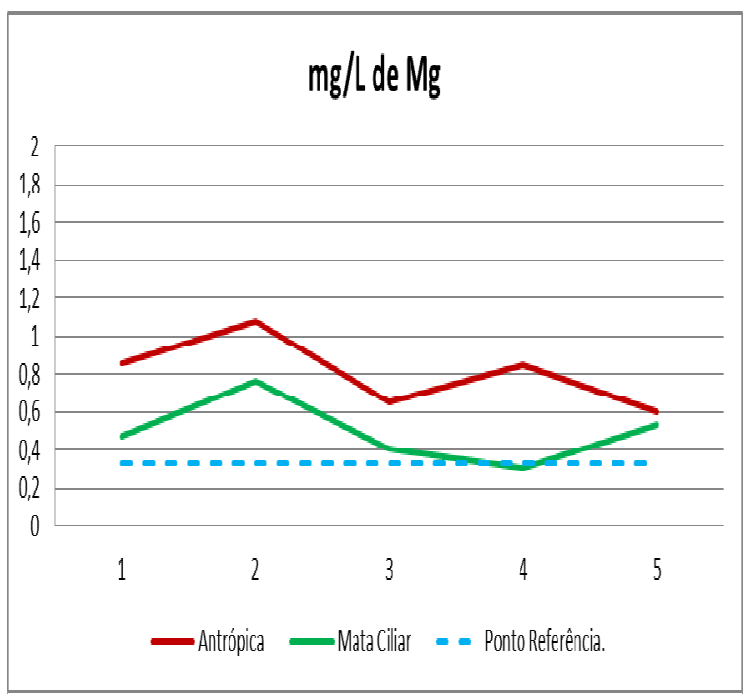

Gráfico 22 - Sódio (mg/L) - Dado Bruto

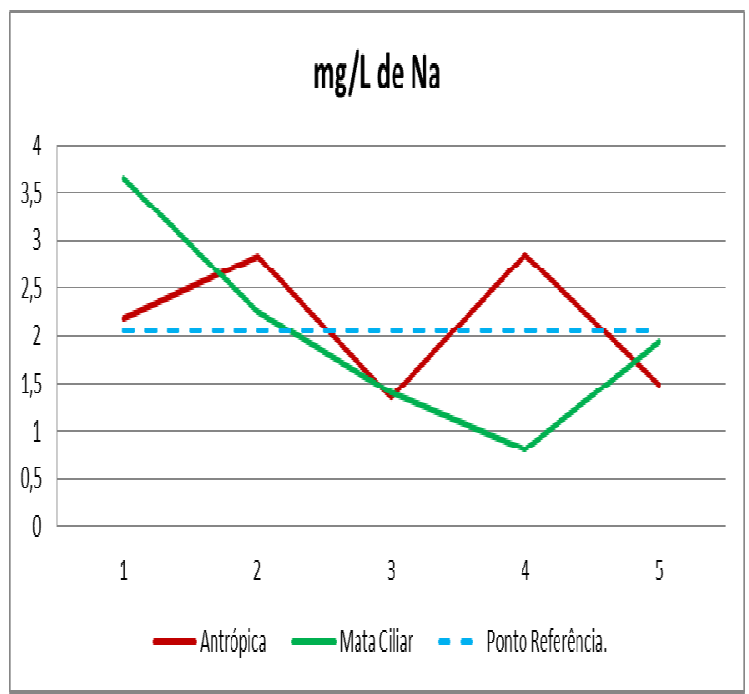

Gráfico 21 - Magnésio (mg/L) - Média

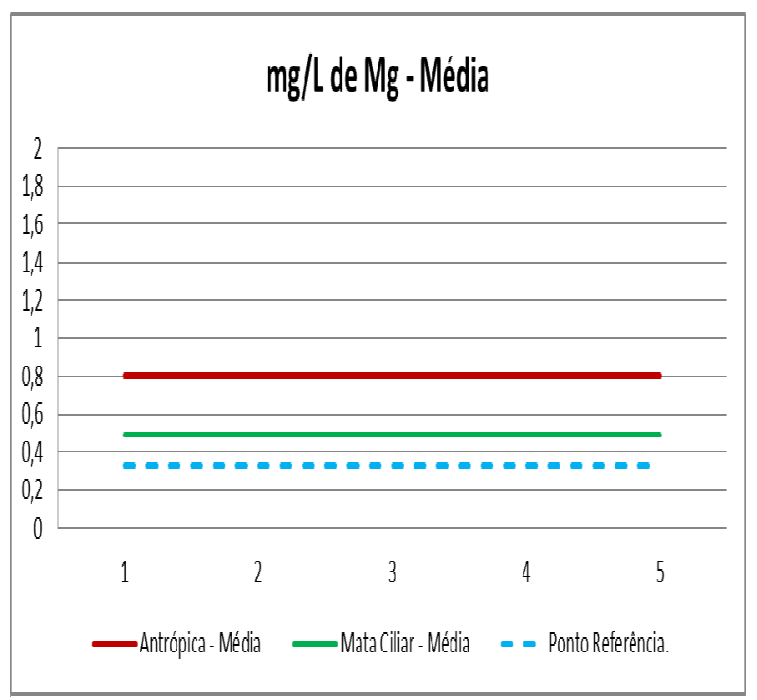

Gráfico 23 - Sódio (mg/L) - Média

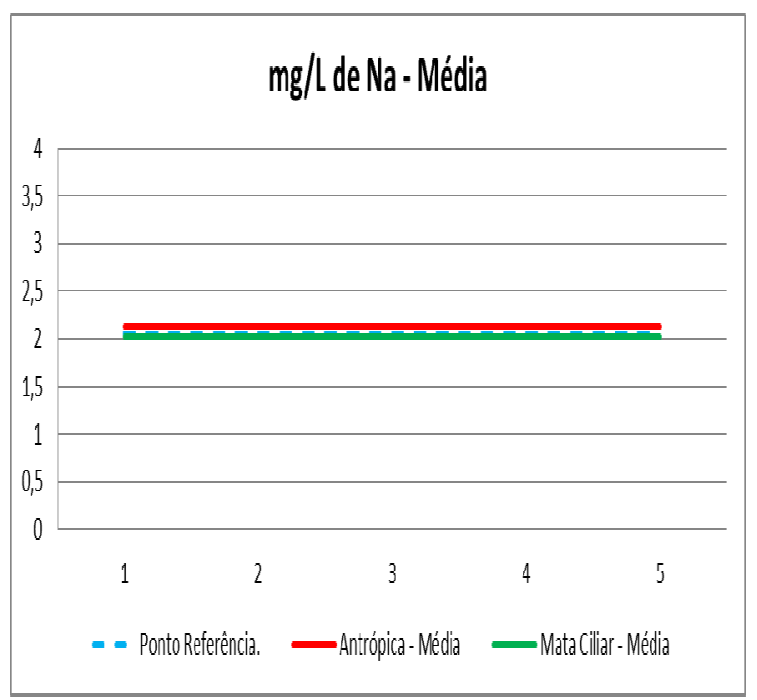


Gráfico 24 - Zinco (mg/L) - Dado Bruto

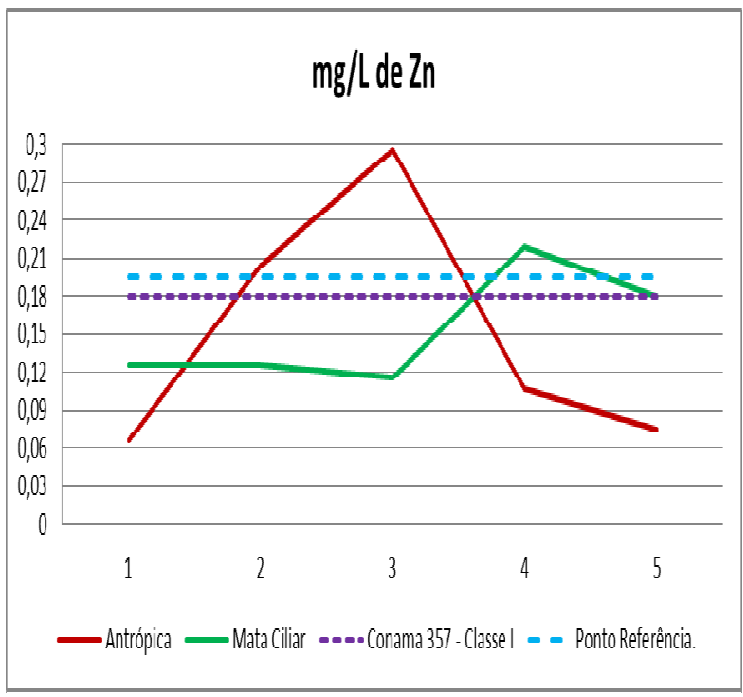

Gráfico 26 - Fósforo (mg/L) - Dado Bruto

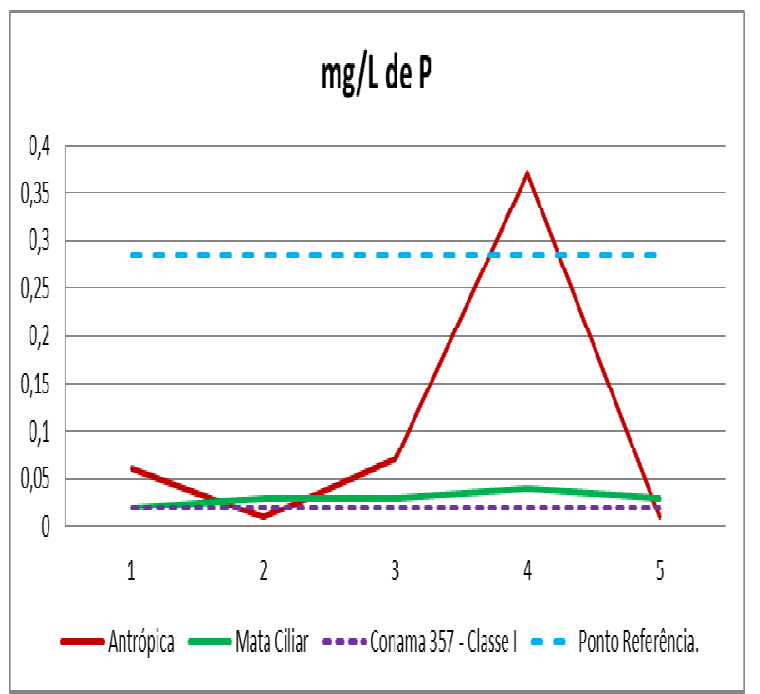

Gráfico 25 - Zinco (mg/L) - Média

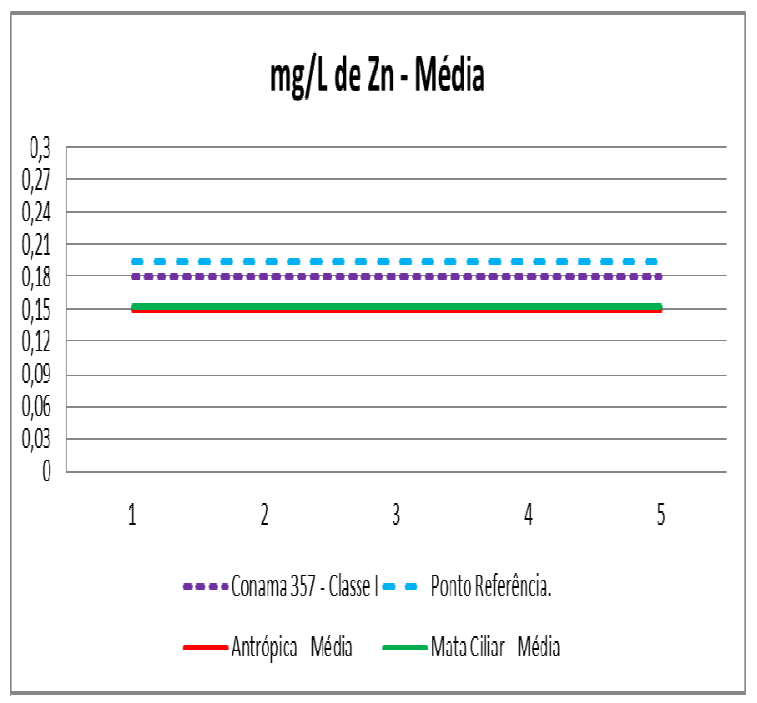

Gráfico 27 - Fósforo (mg/L) - Média

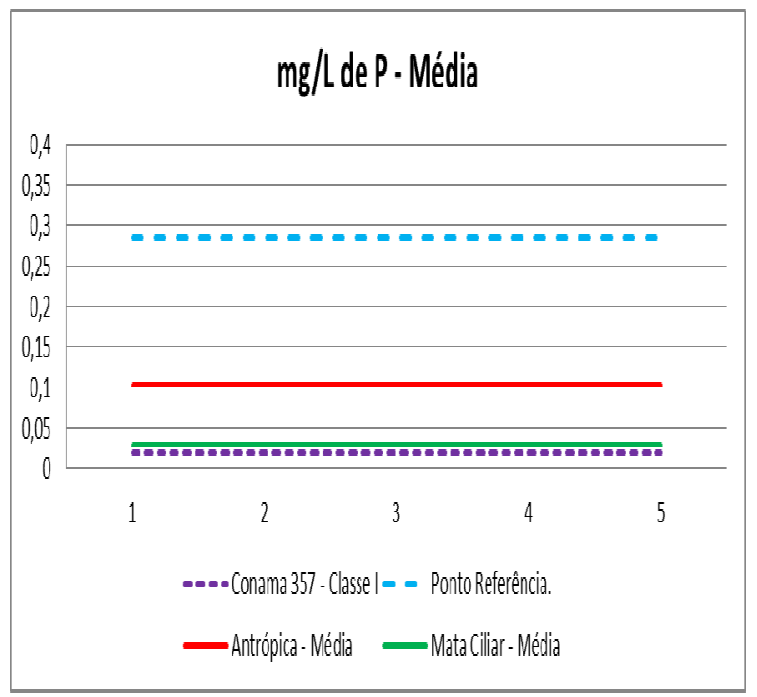




\subsection{Apresentação dos resultados do compartimento sedimentos de fundo}

Tabela 9 - Resultados dos elementos químicos encontrados nos sedimentos de fundo analisados em laboratório para o Reservatório de Biritiba-Mirim (SP) na área protegida por mata ciliar (amostras EDL 1,2,3,4,5).

\begin{tabular}{c|c|c|c|c|c|c}
\hline $\begin{array}{c}\text { Elemento } \\
\text { Químico }\end{array}$ & EDL1 & EDL2 & EDL3 & EDL4 & EDL5 & Média \\
\hline $\mathrm{Na}_{2} \mathrm{O}(\mathrm{mg} / \mathrm{kg})$ & $<10$ & $<10$ & 290 & 190 & 350 & 170 \\
\hline $\mathrm{Al}_{2} \mathrm{O}_{3}(\mathrm{mg} / \mathrm{kg})$ & 16.100 & 30.100 & 39.500 & 39.100 & 115.000 & 47.960 \\
\hline $\mathrm{P}_{2} \mathrm{O}_{5}(\mathrm{mg} / \mathrm{kg})$ & 210 & 300 & 350 & 410 & 870 & 430 \\
\hline $\mathrm{CaO}(\mathrm{mg} / \mathrm{kg})$ & 780 & 850 & 260 & 290 & 490 & 534 \\
\hline $\mathrm{Fe} \mathrm{O}_{3}(\mathrm{mg} / \mathrm{kg})$ & 4.530 & 7.750 & 8.900 & 8.570 & 19.000 & 9.750 \\
\hline $\mathrm{ZnO}(\mathrm{mg} / \mathrm{kg})$ & $<10$ & $<10$ & $<10$ & $<10$ & 50 & 18 \\
\hline $\mathrm{MgO}(\mathrm{mg} / \mathrm{kg})$ & $<10$ & $<10$ & $<10$ & $<10$ & $<10$ & 10 \\
\hline
\end{tabular}

Nota: Estão tabelados apenas os valores dos elementos químicos que também foram analisados para água e que se apresentaram acima dos limites de quantificação do aparelho e suas respectivas médias aritméticas.

Tabela 10 - Resultados dos elementos químicos encontrados nos sedimentos de fundo analisados em laboratório para o Reservatório de Biritiba-Mirim (SP) na área antrópica agrícola (EDS 1,2,3,4,5).

\begin{tabular}{c|c|c|c|c|c|c}
\hline $\begin{array}{c}\text { Elemento } \\
\text { Químico }\end{array}$ & EDS1 & EDS2 & EDS3 & EDS4 & EDS5 & Média \\
\hline $\mathrm{Na}_{2} \mathrm{O}(\mathrm{mg} / \mathrm{kg})$ & $<10$ & $<10$ & 610 & $<10$ & 310 & 190 \\
\hline $\mathrm{Al}_{2} \mathrm{O}_{3}(\mathrm{mg} / \mathrm{kg})$ & 41.200 & 7.150 & 336.000 & 15.200 & 69.000 & 93.710 \\
\hline $\mathrm{MgO}(\mathrm{mg} / \mathrm{kg})$ & 850 & $<10$ & $<10$ & $<10$ & 500 & 276 \\
\hline $\mathrm{P}_{2} \mathrm{O}_{5}(\mathrm{mg} / \mathrm{kg})$ & 8.280 & 350 & 10.800 & 540 & 2.590 & 4.512 \\
\hline $\mathrm{CaO}(\mathrm{mg} / \mathrm{kg})$ & 7.660 & 250 & 2.430 & 240 & 1.390 & 2.394 \\
\hline $\mathrm{Fe}_{2} \mathrm{O}_{3}(\mathrm{mg} / \mathrm{kg})$ & 5.530 & 1.440 & 35.000 & 2.200 & 5.820 & 9.998 \\
\hline $\mathrm{ZnO}(\mathrm{mg} / \mathrm{kg})$ & 80 & $<10$ & 160 & $<10$ & $<10$ & 54 \\
\hline
\end{tabular}

Nota: Estão tabelados apenas os valores dos elementos químicos que também foram analisados para água e que se apresentaram acima dos limites de quantificação do aparelho e suas respectivas médias aritméticas. 
Tabela 11 - Resultados dos elementos químicos encontrados nos sedimentos de fundo analisados em laboratório para o Ribeirão Biritiba-Mirim, no ponto considerado de referência (PBM1 e PB2J).

\begin{tabular}{c|c|c|c}
\hline Elemento Químico & PB1M & PB2J & Média \\
\hline $\mathrm{Na}_{2} \mathrm{O}(\mathrm{mg} / \mathrm{kg})$ & 360 & 1.350 & 855 \\
\hline $\mathrm{Al}_{2} \mathrm{O}_{3}(\mathrm{mg} / \mathrm{kg})$ & 31.700 & 27.000 & 29.350 \\
\hline $\mathrm{P}_{2} \mathrm{O}_{5}(\mathrm{mg} / \mathrm{kg})$ & 160 & 280 & 220 \\
\hline $\mathrm{CaO}(\mathrm{mg} / \mathrm{kg})$ & 150 & 950 & 550 \\
\hline $\mathrm{Fe}_{2} \mathrm{O}_{3}(\mathrm{mg} / \mathrm{kg})$ & 3.720 & 3.940 & 3.830 \\
\hline $\mathrm{MgO}(\mathrm{mg} / \mathrm{kg})$ & - & - & - \\
\hline $\mathrm{ZnO}(\mathrm{mg} / \mathrm{kg})$ & - & - & - \\
\hline
\end{tabular}

Nota: Estão tabelados apenas os valores dos elementos químicos que também foram analisados para água e que se apresentaram acima dos limites de quantificação do aparelho e suas respectivas médias aritméticas.

Tabela 12 - Comparação entre os Valores Máximos Permitidos de elementos químicos em sedimentos de fundo segundo PEL/TEL (CETESB/2011), Valores Orientadores para Solo CETESB/2014 e Valores para Sedimento CONAMA 454/2012.

\begin{tabular}{c|c|c|c}
\hline \multirow{2}{*}{ Parâmetros } & $\begin{array}{c}\text { TEL e PEL - } \\
\text { CETESB/2011 }\end{array}$ & $\begin{array}{c}\text { Valores Orientadores } \\
\text { para Solo - } \\
\text { CETESB/2014 }\end{array}$ & $\begin{array}{c}\text { Valores para Sedimento - } \\
\text { CONAMA 454/2012 }\end{array}$ \\
\cline { 2 - 4 } & Ótima & $\begin{array}{c}\text { Referência de } \\
\text { Qualidade (mg/kg) }\end{array}$ & $\begin{array}{c}\text { Água Doce Nível 1 } \\
\text { (mg/kg) }\end{array}$ \\
\hline $\mathrm{As}(\mathrm{mg} / \mathrm{kg})$ & $<5,9$ & & \\
\hline $\mathrm{Cd}(\mathrm{mg} / \mathrm{kg})$ & $<0,6$ & & 35 \\
\hline $\mathrm{Pb}(\mathrm{mg} / \mathrm{kg})$ & $<35,0$ & 17 & 35,7 \\
\hline $\mathrm{Cu}(\mathrm{mg} / \mathrm{kg})$ & $<35,7$ & 35 & \\
\hline $\mathrm{Cr}(\mathrm{mg} / \mathrm{kg})$ & $<37,3$ & & \\
\hline $\mathrm{Hg}(\mathrm{mg} / \mathrm{kg})$ & $<0,170$ & & 123 \\
\hline $\mathrm{Ni}(\mathrm{mg} / \mathrm{kg})$ & $<18$ & & 2000 (valor alerta) $^{*}$ \\
\hline $\mathrm{Zn}(\mathrm{mg} / \mathrm{kg})$ & $<123$ & 60 & \\
\hline Fósforo Total $(\mathrm{mg} / \mathrm{kg})$ & & & \\
\hline
\end{tabular}

* Valor alerta: Valor acima do qual representa possibilidade de causar prejuízo ao ambiente na área de disposição. 
5.2.1 Apresentação gráfica dos resultados dos elementos químicos nos sedimentos de fundo realizados em laboratório nos pontos de amostragem EDS 1,2,3,4,5 (Antrópica); EDL 1,2,3,4,5 (Mata Ciliar); PB1M e PB2J (Ponto Referência), com base nas tabelas 9, 10 e 11, respectivamente.

Gráfico 28 - Alumínio (mg/kg)-Dado Bruto

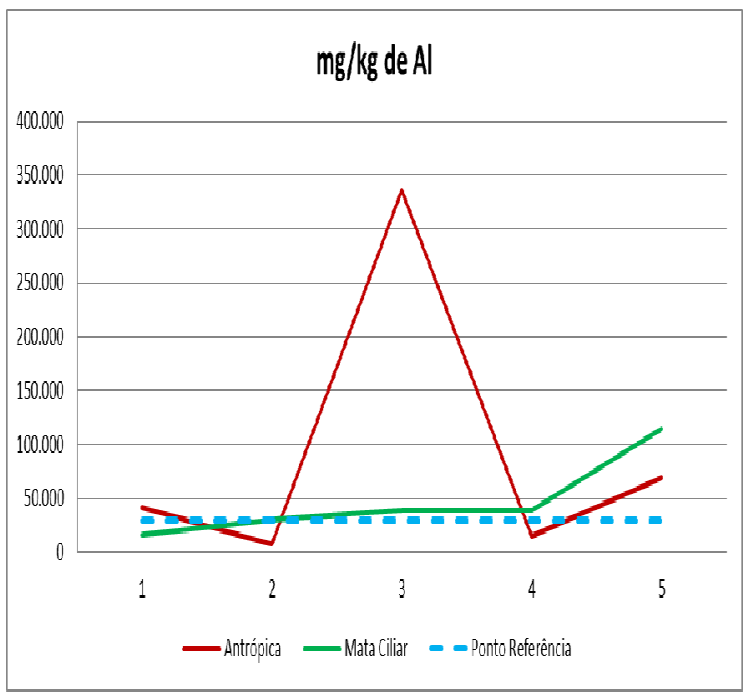

Gráfico 30 - Cálcio (mg/kg) - Dado Bruto

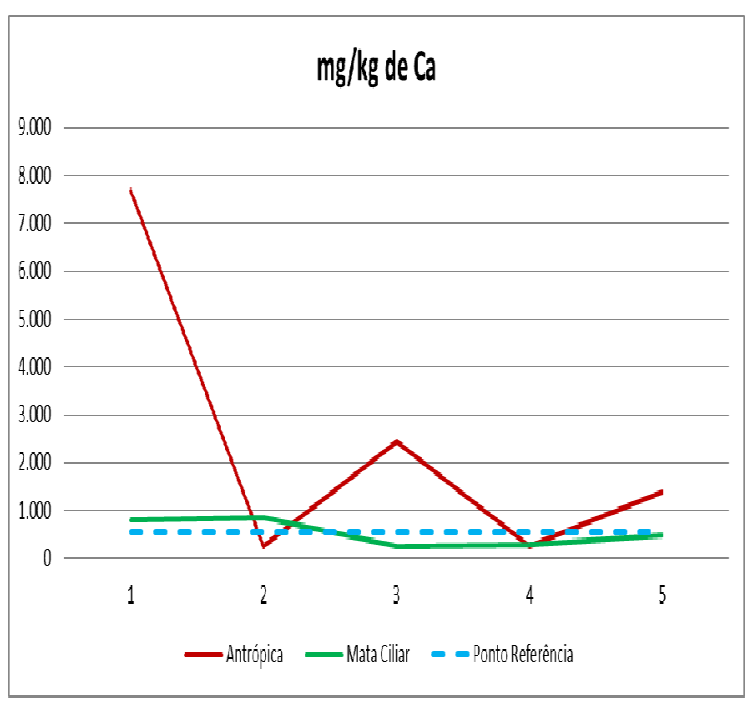

Gráfico 29 - Alumínio (mg/kg)-Média

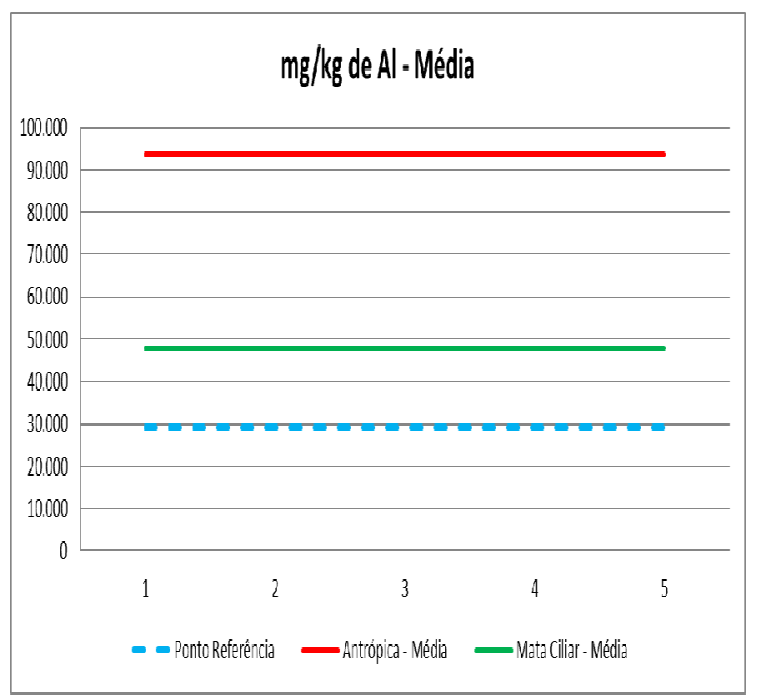

Gráfico 31 - Cálcio $(\mathrm{mg} / \mathrm{kg})$ - Média

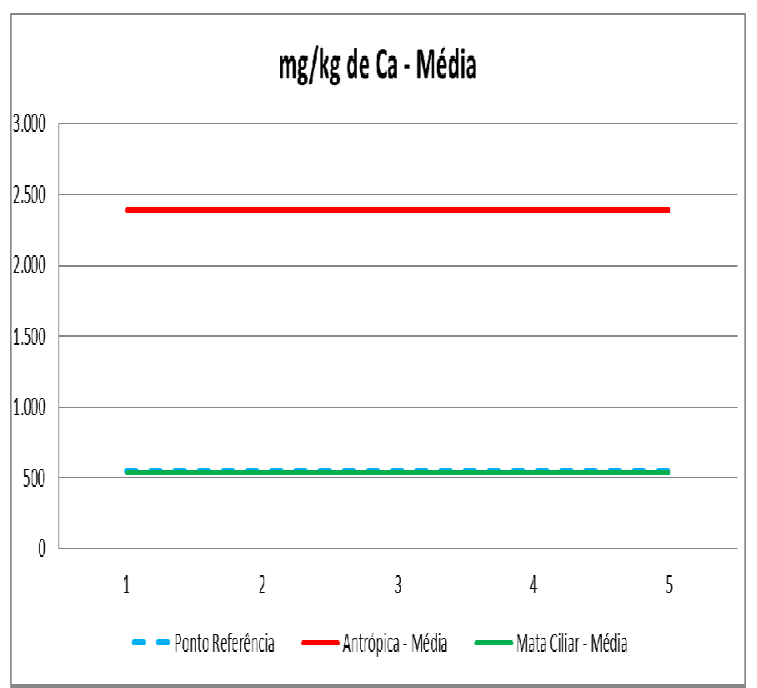


Gráfico 32 - Ferro (mg/kg) - Dado Bruto

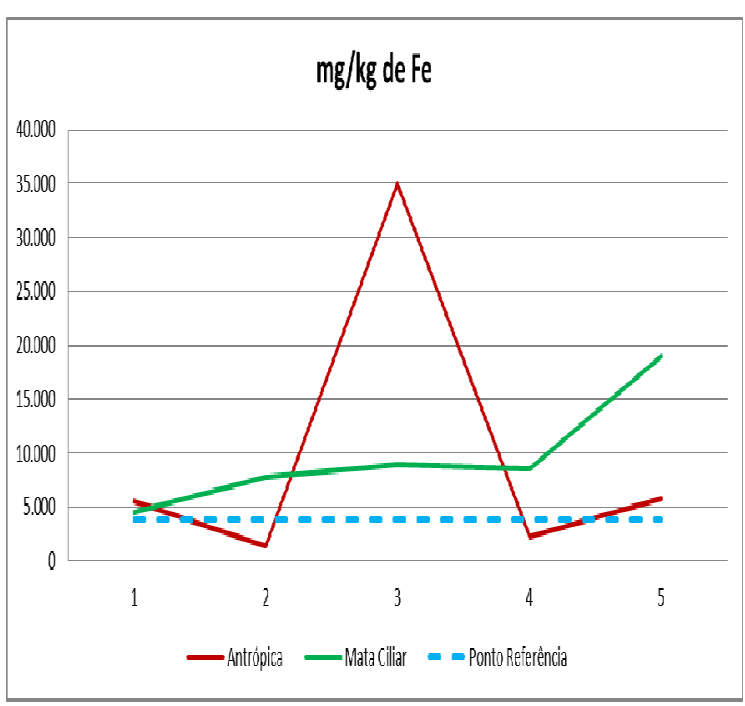

Gráfico 34 - Magnésio (mg/kg)-Dado Bruto

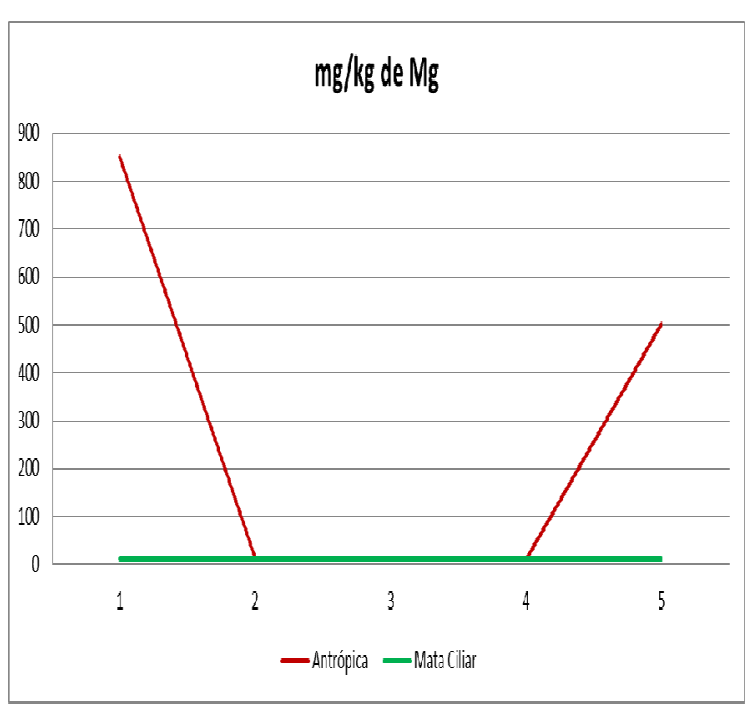

Gráfico 33 - Ferro (mg/kg) - Média

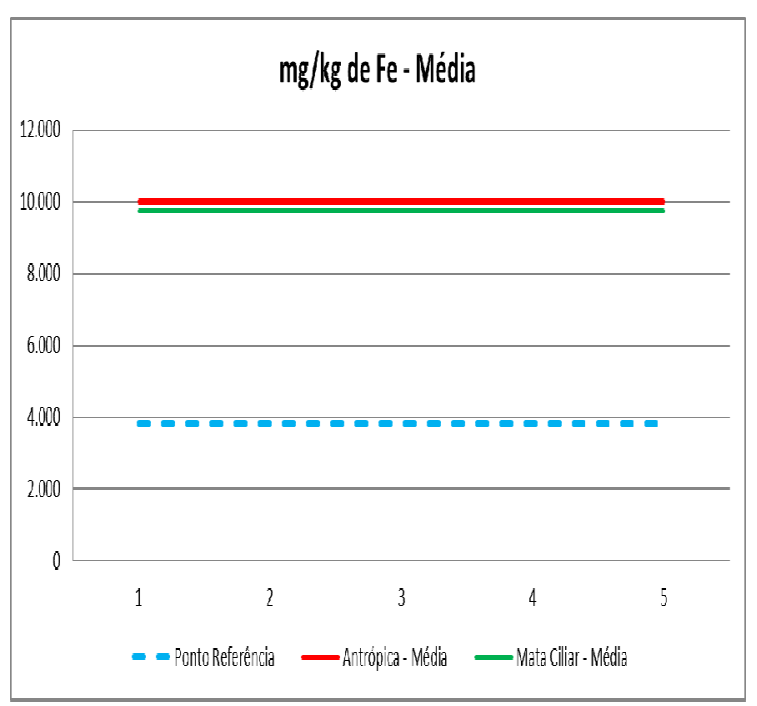

Gráfico 35 - Magnésio (mg/kg)-Média

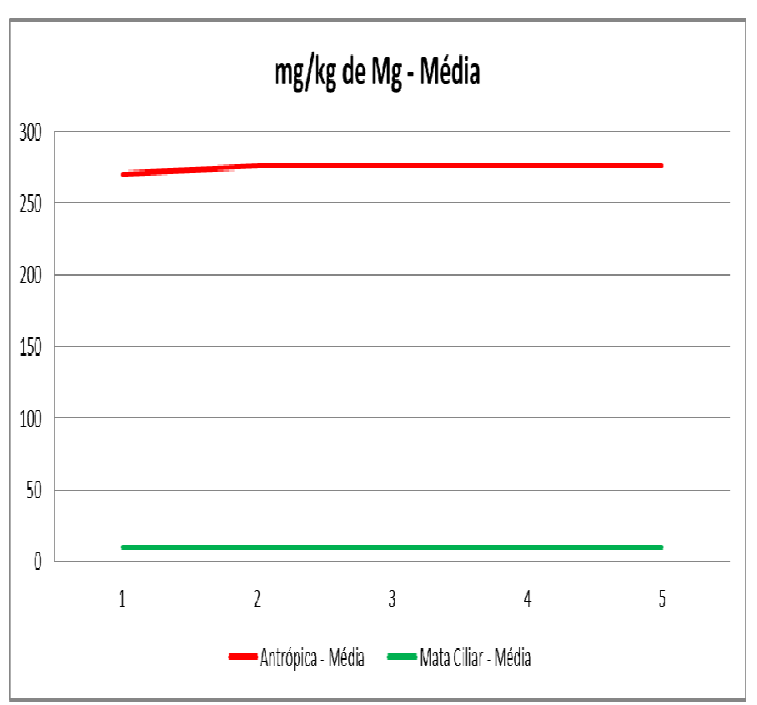


Gráfico 36 - Sódio (mg/kg) - Dado Bruto

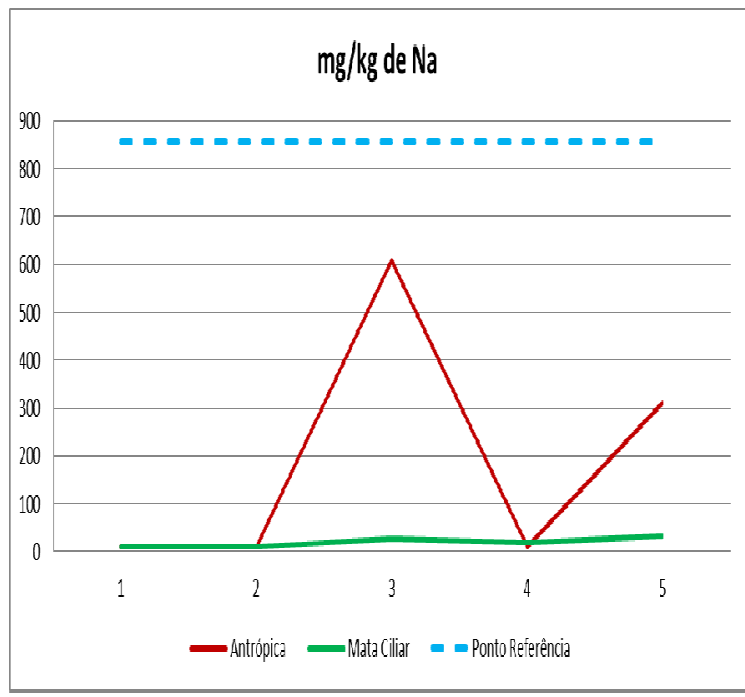

Gráfico 38 - Zinco (mg/kg) - Dado Bruto

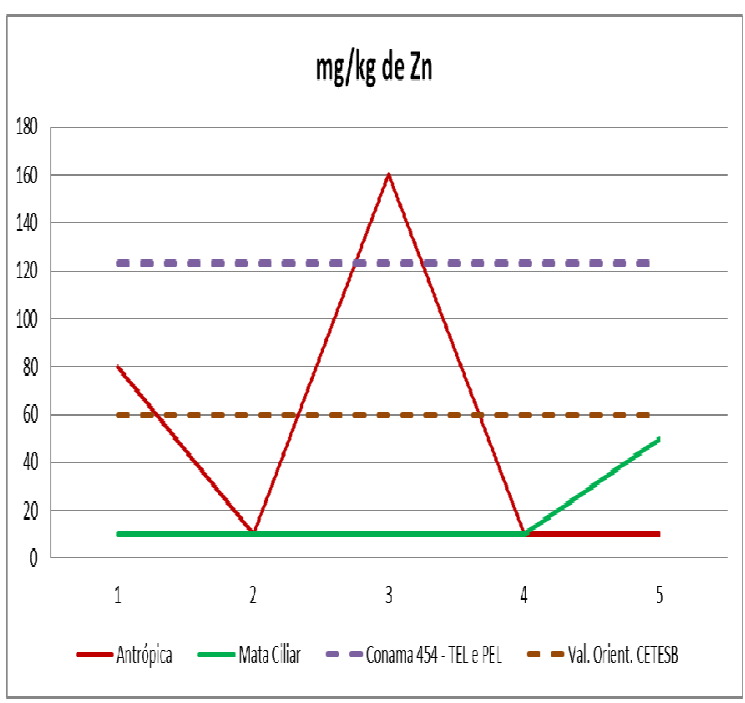

Gráfico 37 - Sódio (mg/kg) - Média

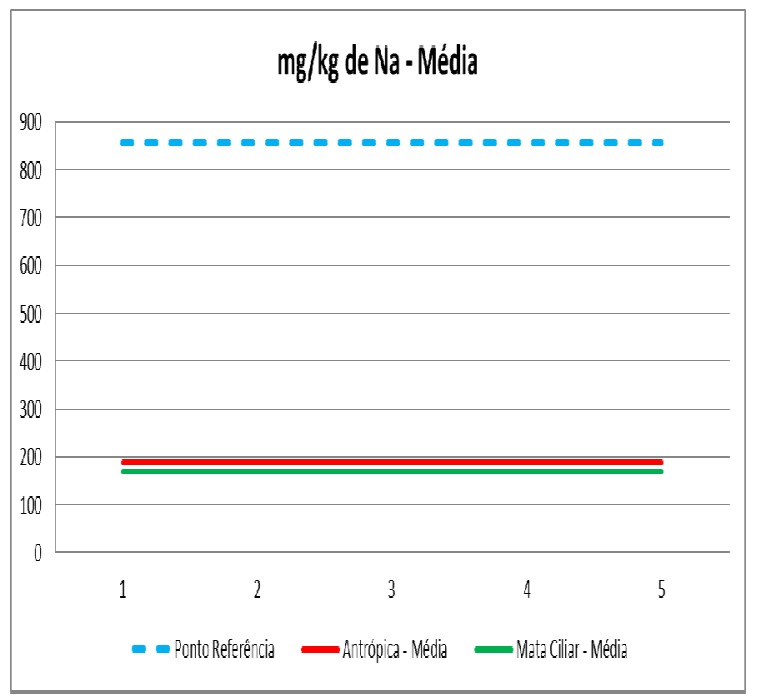

Gráfico 39 - Zinco (mg/kg) - Média

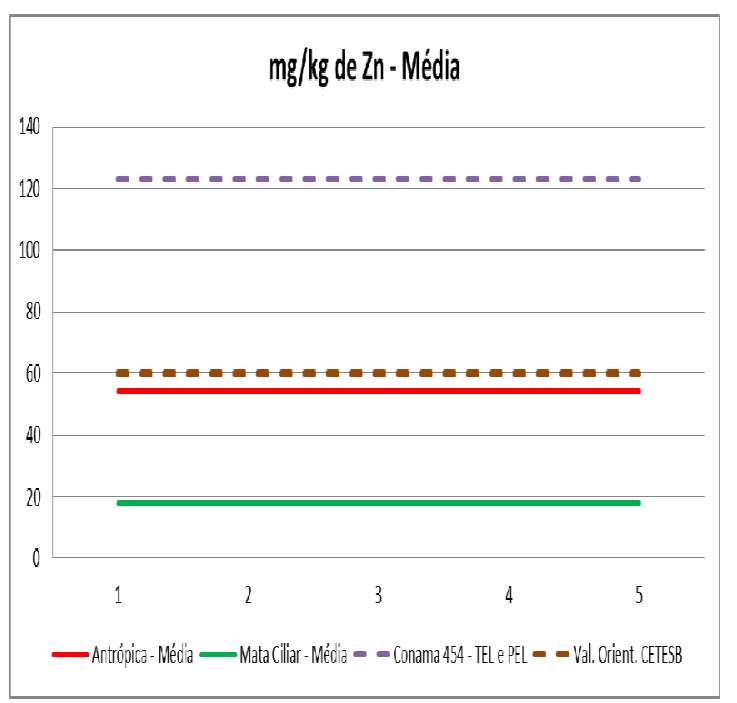


Gráfico 40 - Fósforo (mg/kg) - Dado Bruto

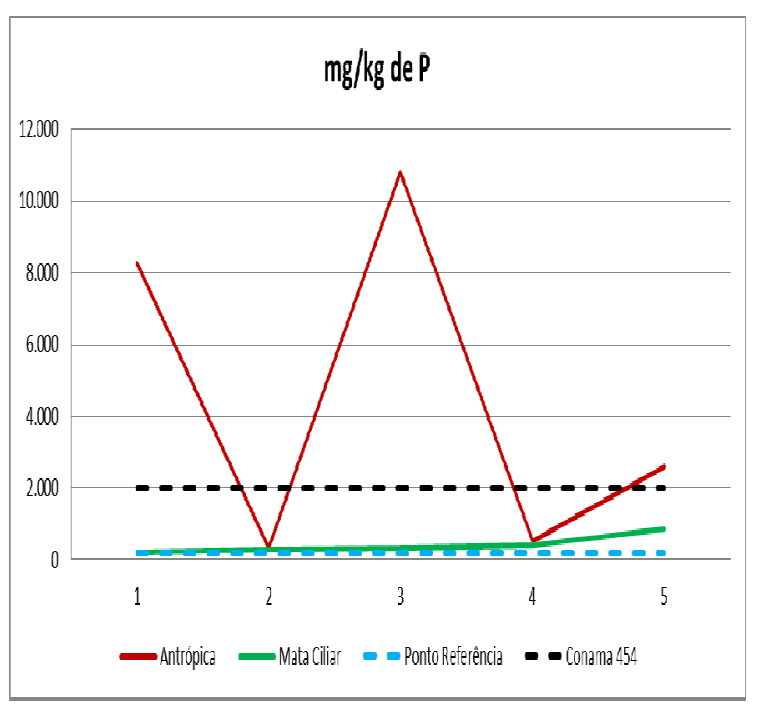

Gráfico 41 - Fósforo (mg/kg) - Média

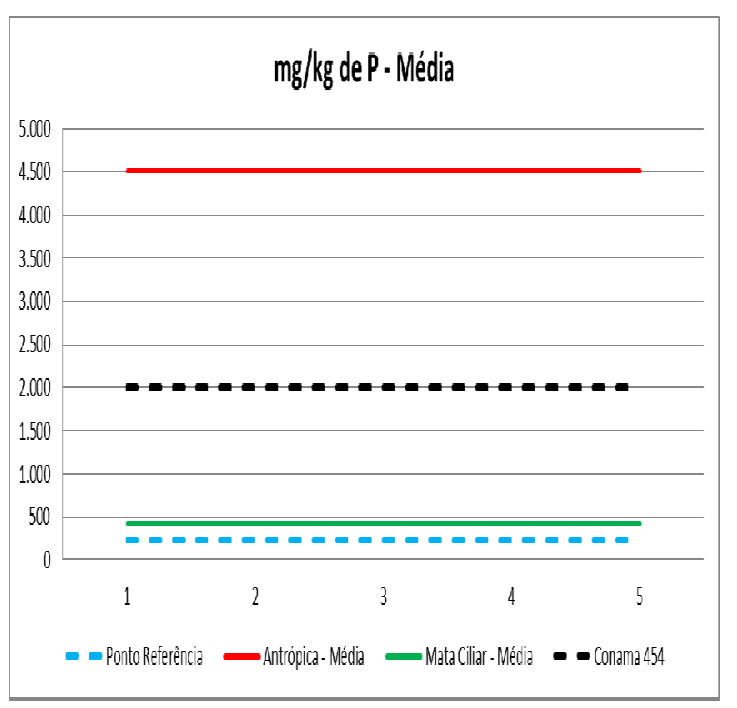

\subsection{Análise dos resultados}

A etapa inicial de avaliação das imagens de satélite LANDSAT 5, destacou a condição antagônica entre a área de estudo que apresenta pressão antrópica agrícola e a área de estudo que apresenta proteção por mata ciliar (Figura 16).

A etapa de caracterização da área de estudo com proteção de mata ciliar, apresentou um fragmento dimensionado em aproximadamente 70 metros em projeção horizontal e 250 metros de comprimento em área de preservação permanente. Caracterizado conforme Resolução CONAMA № 10/1993, estágio médio a avançado de regeneração, com fisionomia arbórea, dominante sobre as demais, formando um dossel fechado e relativamente uniforme no porte, apresentando árvores emergentes com distribuição diamétrica de amplitude moderada, com predomínio de pequenos a médios diâmetros; trepadeiras, quando presentes são predominantemente lenhosas; diversidade biológica significativa subbosque presente. 
A etapa de avaliação dos resultados analíticos para verificar a presença ou não de metais e outros elementos químicos potencialmente tóxicos e do uso de agroquímicos na água e nos sedimentos de fundo do reservatório de Biritiba-Mirim (SP) envolveu, a análise dos dados brutos e médios e gráfica comparativa de parâmetros ambientais presentes na água e nos sedimentos de fundo, que evidenciaram alterações de qualidade na área antrópica agrícola e área protegida por mata ciliar, e também com o ponto referência (controle) proveniente de uma porção da área de estudo com pouca ou nenhuma incidência de atividade antrópica agrícola. 


\section{DISCUSSÃo}

\subsection{Discussão referente aos parâmetros físico-químicos encontrados na Água}

As determinações analíticas obtidas, revelam variações significativas dos parâmetros físico-químicos nos pontos monitorados do reservatório de Biritiba-Mirim (SP) e a influência do uso e ocupação por atividade agrícola e da proteção da mata ciliar no seu entorno e o impacto na qualidade da água, utilizada para abastecimento público, levando em consideração também, as características litológicas da área de estudo, quando possível.

\subsubsection{Potencial Hidrogeniônico $(\mathrm{pH})$}

De acordo com Mcneely, Neimanis e Dwyer (1979) o Potencial Hidrogeniônico $(\mathrm{pH})$ e Oxigênio dissolvido (OD) possuem uma relação intrínseca em um sistema aquático, pois o pH é capaz de provocar alterações em um corpo hídrico, e influenciar processos biológicos como a fotossíntese e respiração, enquanto o teor de oxigênio dissolvido altera o pH pela variação do conteúdo de dióxido de carbono.

$\mathrm{O} \mathrm{pH}$ da maioria das águas naturais varia entre 6,0 e 8,5. Valores menores podem ocorrer em águas com elevada concentração de matéria orgânica (CHAPMAN, 1992).

Von Sperling, (2005), afirma que valores de $\mathrm{pH}$ muito afastados da neutralidade podem afetar a vida aquática, como peixes e microrganismos (fitoplancton, zooplancton etc).

Analisando as Tabelas 2, 3 e 4 e gráficos 2 e 3, observa-se que na área protegida por mata ciliar o índice de pH médio se apresenta levemente ácido, muito próximo da neutralidade, corroborando com DAEE (1997), onde descreve que antes 
do enchimento do reservatório Biritiba-Mirim (SP), os índices de $\mathrm{pH}$ do rio oscilavam entre neutro com leve tendência à acidez devido a baixos valores de alcalinidade e dureza total. $\mathrm{Na}$ área de referência o valor de $\mathrm{pH}$ médio se apresenta ácido, evidenciando que as áreas mais protegidas e com presença de vegetação em seu entorno, ocorre desfolhamento, degradação das folhas e da matéria orgânica natural, propiciando a formação de ácidos húmicos e fúlvicos, que também provocam acidez na água, além do que descrevem Silva et al. (2010), onde o pH também pode refletir o tipo de solo que as águas percorrem ao longo da bacia. Os menores índices de $\mathrm{pH}$ presentes na área antrópica agrícola comparado com os da área protegida por mata ciliar, pode ser devido a presença de matéria orgânica de origem antropogênica nessa porção. Ressalta-se que $75 \%$ dos resultados de $\mathrm{pH}$ se apresentam conforme o padrão de qualidade estabelecido pela CONAMA 357/05 Classe I, que é de 6 a 9, as exceções são os dois pontos de referência PB1M e PB2J e o ponto EDS1.

\subsubsection{Oxigênio Dissolvido (OD) (mg/L)}

Para o parâmetro oxigênio dissolvido, em corpos d'água de classe I, como classificado o reservatório de Biritiba-Mirim (SP), a resolução CONAMA 357/2005 estabelece valores superiores a $6 \mathrm{mg} / \mathrm{L}$. Nas tabelas 2,3 e 4 e gráficos 4 e 5 observa-se que na área referência e protegida por mata ciliar, os valores de oxigênio dissolvido se apresentam superiores aos da área antrópica agrícola, e também em conformidade com valor estabelecido pela resolução CONAMA 357/05. Segundo FATMA (1999) e Von Sperling (2005), processos de consumo de oxigênio na decomposição de compostos orgânicos das substancias lançadas na água, podem ser um indicativo da presença de poluente na água. De acordo com British Columbia (1998), as fontes antrópicas que causam decréscimo de oxigênio são: 
desflorestamento, efluentes de fabricas, agricultura, efluentes de esgotos domésticos e estações de tratamento e alagamentos (lagos).

Como as determinações para os pontos EDS4 e EDS5 foram realizadas em dias diferentes na área antrópica agrícola, observa-se uma tendência de aumento significativo nos valores para o parâmetro OD no dia 12/06/2013, diferente da determinação do dia 18/06/2013 (Tabela 2), onde os valores de OD se apresentaram inferiores aos preconizados pela resolução CONAMA 357/05, essa inconsistência pode ser devido às condições climáticas propícias à atividade fitoplanctônica no dia 12/06/2012, que proporcionou um aumento nos valores de OD através das reações fotossintéticas. Esse fenômeno não foi observado na área protegida por mata ciliar, muito provável, devido a sua maior estabilidade química, física e biológica. As determinações de OD realizadas nos dois pontos de referência, se apresentaram acima de 7,5 mg/L, estando assim em conformidade com a resolução CONAMA 357/05 (Tabela 4).

Além de que quanto menor a temperatura, maior a quantidade de oxigênio dissolvido a água consegue reter, situação coerente com os resultados apresentados. Ressalta-se também que os resultados de OD da área protegida por mata ciliar e da área referência, se apresentaram todos em média, conforme os padrões da Resolução Conama 357/05 para copos d'água de Classe I, que é o caso do Reservatório de Biritiba-Mirim (SP).

\subsubsection{Temperatura $\left({ }^{\circ} \mathrm{C}\right)$}

Conforme dados apresentados nas tabelas 2, 3 e 4, e gráficos 6 e 7 no reservatório de Biritiba-Mirim (SP) ao longo dos pontos de amostragem (referência PB1M e PB2J, antrópica agrícola - EDS 1,2,3,4,5, e mata ciliar EDS 1,2,3,4,5) foi observado aumento médio de temperatura da área referência para as demais áreas 
a jusante, de $4,65{ }^{\circ} \mathrm{C}$ comparado com a área antrópica agrícola e de $4,14{ }^{\circ} \mathrm{C}$ comparado com a área protegida com mata ciliar. Confrontando a média de temperatura da área antrópica agrícola com a área protegida com mata ciliar, observa-se também uma diferença de $0,51{ }^{\circ} \mathrm{C}$. Esse fenômeno pode ter sido determinado pela maior estabilidade térmica das áreas protegidas por mata ciliar (STEINBLUMS; FROELICH; LYONS, 1984).

A luz desta dissertação, este autor entende que nas áreas não protegidas por mata ciliar, o espelho d'água do reservatório fica mais exposto a luz solar, corroborando para o aumento da temperatura da água, potencializando as atividades biológicas para oxidação da matéria orgânica, resultando na maior depleção de oxigênio nessas áreas.

A diferença estatisticamente significativa entre a referência e as áreas dentro do reservatório, indicando que essa variação pode estar associada ao acúmulo de calor nas massas de água represadas que também foi observado no estudo de Sendacz et al. (2005), no rio Paranapanema, em SP. Segundo Braga, Rebouças e Tundisi (2006), a construção de um reservatório resulta em concentrações de massas de água maiores, podendo alterar a temperatura da água não só localmente, mas dos rios a jusante também. Ressalta-se também a diferença média de temperatura de $0,51^{\circ} \mathrm{C}$ entre a área antrópica agrícola e a área protegida por mata ciliar, que evidencia a importância do conforto térmico propiciado pela presença de vegetação no entorno do reservatório.

\subsubsection{Condutividade elétrica $(\mu \mathrm{S} / \mathrm{cm})$}

Para o parâmetro condutividade, não é estabelecido limite, mas segundo a CETESB (2014), a quantidade de sais existentes na água, pode representar indiretamente a concentração de poluentes ou de aumento de cátions na água, 
alguns potencialmente tóxicos. A água possui potencial de ionização baixo e, portanto, pequenas quantidades de soluções condutoras nela dissolvidas (ácidos inorgânicos, bases e sais). Níveis superiores a $100 \mu \mathrm{S} / \mathrm{cm}$, indicam que o ambiente foi impactado ou vem recebendo carga de elementos químicos de origem natural. $A$ condutividade da água aumenta à medida que mais sólidos dissolvidos são adicionados e altos valores podem indicar características com tendência a exibir degradação da qualidade da água.

Os índices de condutividade elétrica observados nas tabelas 2, 3 e 4, e gráficos 8 e 9, nas três áreas monitoradas se apresentaram em média relativamente baixos, com 33,2 $\mu \mathrm{S} / \mathrm{cm}$ para a área antrópica agrícola, $31 \mu \mathrm{S} / \mathrm{cm}$ para área protegida por mata ciliar e $16,5 \mu \mathrm{S} / \mathrm{cm}$ para a área referência. A diferença no índice de condutividade elétrica entre o ponto referência quando comparado com as médias dos demais pontos analisados nesse estudo, no entanto, pode-se notar um acentuado aumento de $16,7 \mu \mathrm{S} / \mathrm{cm}$ dos valores nas regiões com presença de maior atividade antrópica agrícola e de $14,5 \mu \mathrm{S} / \mathrm{cm}$ onde foi observada a presença de mata ciliar.

Observa-se também uma variação média de 2,2 $\mu \mathrm{S} / \mathrm{cm}$ entre a área antrópica agrícola e a área protegida por mata ciliar. Essa diferença pode ter sido determinada pela barreira de proteção, servindo como uma espécie de filtro retentor de elementos contra o carreamento de sais, exercida pela área protegida por mata ciliar.

Resultados semelhantes foram observados por Sendacz et al. (2005), que descrevem maior valor de condutividade elétrica nas regiões com presença de urbanização e menor na presença de mata e reflorestamento. Ao estudar o Alto Tietê Cabeceiras, os autores encontram ainda grande variabilidade nos dados de condutividade. Outro fator a ser considerado é o período de precipitação atípico 
quando da coleta das amostras nessa dissertação, podendo ter interferido nos resultados. Moccellin (2006), em seu estudo observou variação sazonal bem definida da condutividade elétrica, com menores valores no período de maior precipitação pluviométrica, salientando o efeito de diluição que ocorre nas águas e também da influência geológica da bacia hidrográfica resultando em maior quantidade de material lixiviado neste período.

\subsubsection{Turbidez (NTU)}

Segundo Esteves (2011), a turbidez é uma medida da capacidade de dispersão da radiação. Branco (1986) considera que a turbidez de uma água é dada pela presença de partículas em suspensão.

A turbidez, conforme tabelas 2, 3 e 4 e gráficos 10 e 11, foi um dos parâmetros que distinguiu a área antrópica agrícola da área protegida por mata ciliar na borda do reservatório. Como as determinações para os pontos EDS4 e EDS5 foram realizadas em dias diferentes na área antrópica agrícola, observa-se uma tendência de queda significativa nos valores para o parâmetro turbidez no dia 12/06/2013, diferente da determinação do dia 18/06/2013, onde os valores de turbidez se apresentaram coerentemente mais elevados que a área protegida por mata ciliar, essa inconsistência pode ter sido devido a alguma alteração no corpo hídrico no dia 12/06/2012, que também comprometeram os valores médios comparativos entre a área antrópica agrícola e área protegida por mata ciliar, como a presença de partículas em suspensão devido a um evento pluviométrico. $O$ parâmetro turbidez, no entanto, se apresentou com valores ainda menores nos pontos referência, fator que demonstra a diferença dos impactos causados pela atividade antrópica na área agrícola da área mais protegida por mata ciliar. No entanto nas três áreas determinadas, os valores de turbidez não foram significativos 
e também não ultrapassaram o limite permitido pela resolução no 357 do CONAMA que é de 40 NTU para águas doces classe I.

\subsubsection{Potencial de Oxirredução (mV)}

Segundo Oliveira, Leal e Velloso (1993), o potencial redox representa o parâmetro físico-químico mais importante na caracterização do grau de oxidação ou redução de um solo submerso. O potencial redox (ORP) é o potencial de oxidação e redução de um ambiente, mede as cargas negativas e positivas, ou seja, se houver um ambiente oxidante, significa que haverá um ORP positivo - mais elementos oxidantes que redutores - e vice-versa.

Para Enzweiler (2010), o desenvolvimento de certos tipos de organismos, como parasitas e bactérias, é inibido com índices elevados de ORP.

Segundo Souza (2015), a presença de uma água limpa, resulta em um alto nível de potencial redox, significando capacidade imediata de oxidar elementos tóxicos. Os valores de Potencial Redox em ambientes com ausência de oxigênio dissolvido se apresentam em níveis negativos, podendo indicar um nível alto de estagnação e anaerobiose, caracterizando um ambiente intensamente impactado, gerado por algum tipo de poluição, principalmente de origem orgânica.

Nas tabelas 2, 3 e 4 e gráficos 12 e 13 observa-se que na área com proteção por mata ciliar, os valores de ORP se apresentam superiores aos da área antrópica agrícola, devido às condições de estagnação e anaerobiose da área antrópica agrícola, onde há um elevado acúmulo de matéria orgânica, pelo fato destes ambientes serem fortemente impactados por poluição de fontes difusas, especialmente pelo carreamento de matéria orgânica, fertilizantes e defensivos agrícolas advindos das atividades agrícolas do entorno do reservatório de BiritibaMirim (SP). Essa observação também é válida quando os dados são comparados 
pela média de cada área. Esses valores de ORP corroboram com os que ocorrem nos reservatórios do estado de São Paulo, onde são raros os resultados superiores a $500 \mathrm{mV}$.

\subsection{Discussão referente aos elementos químicos encontrados na Água}

Além das determinações realizadas "in situ" pela Sonda Multiparâmetro Modelo YSI 6820 V2, outros elementos químicos de interesse e que se apresentaram com valores acima do limite de quantificação do aparelho analítico, como Al, $\mathrm{Ca}, \mathrm{Fe}, \mathrm{Mg}, \mathrm{Na}, \mathrm{Zn}$ e $\mathrm{P}$, também foram amostrados e analisados em laboratório. Esses resultados apresentaram diferenças significativas entre as áreas estudadas, onde os pontos localizados na área antrópica agrícola, apresentaram valores nitidamente superiores, quando comparados com os pontos da área com proteção de mata ciliar. Isso também é observado quando os valores médios de cada elemento e de cada área de estudo são comparados (tabelas 5, 6 e 7 e gráficos 14 a 26).

Analisando as tabelas 5, 6, 7 e 8 e gráficos 14 e 15, do elemento químico alumínio, mesmo com alguns resultados se apresentando em não conformidade ao padrão de qualidade estabelecido pela CONAMA 357/05, classe I, no ponto com proteção da mata ciliar, fica evidente a presença de valores mais elevados desse elemento químico na área de estudo denominada antrópica agrícola. Essa observação também é válida quando os dados são comparados pela média de cada área. Comparando com os valores médios desse elemento químico do ponto referência, os resultados se apresentaram mais elevados nesse ponto, provavelmente devido as características do solo da região. De modo análogo Silva (2013), encontrou relações similares às observadas nessa dissertação e explicam ser essa ocorrência resultado do escoamento de partículas contendo esse metal 
aderido a argilominerais, e ou aos agroquímicos utilizados pelos agricultores da região.

Mesmo considerando a regulamentação do CONAMA 357/05, o que se observa na tabela 8, admite-se não existir padrão de qualidade para o parâmetro cálcio, as tabelas 5, 6 e 7 e gráficos 16 e 17 apresentam as diferenças evidentes da menor concentração desse elemento na área protegida por mata ciliar comparada com a área antrópica agrícola. Comparando com o ponto referência, é evidente também que esse ponto apresenta valores médios menores que a área antrópica agrícola e protegida com mata ciliar. Isso devido, provavelmente, a não utilização de corretores de $\mathrm{pH}$ de solo a base de calcário a montante do ponto de referência.

Essa diferença, entre a área com proteção de mata ciliar e antrópica agrícola, fica mais evidente para o conteúdo obtido de ferro nas amostras, conforme tabelas 5, 6 e 7 e gráficos 18 e 19, cujos solos são ricos desse elemento no Complexo Embu e consequentemente na bacia hidrográfica de Biritiba-Mirim (SP). Essas decorrências são produto, principalmente, do carreamento de partículas, através das águas de escoamento, provavelmente, em função das características do solo e carreamento intenso para o sistema aquático, evidenciando a significativa importância da proteção dada pela mata ciliar no Reservatório de Biritiba-Mirim (SP).

O elemento químico magnésio também não é contemplado pelo padrão de qualidade pela CONAMA 357/05, tabela 8. Analisando as tabelas 5, 6 e 7 e gráficos 20 e 21, estes demonstram também uma menor concentração desse elemento na área de estudo protegida por mata ciliar e menor ainda da média do ponto de referência, isso devido também, provavelmente, pela não utilização desse macronutriente para adequação de solo para plantio nessa área. 
Mesmo apresentando um pico de 3,65 mg/L no ponto EDL1, as tabelas 5, 6 e 7 e gráficos 22 e 23, demonstram também que a área protegida por mata ciliar, apresenta valores de sódio menores que na área denominada antrópica agrícola, provavelmente devido ao menor aporte de sais para o corpo hídrico. Essa observação também é válida quando os dados são comparados pela média de cada área.

As tabelas 5, 6 e 7 e gráficos 24 e 25, apresentam para o elemento químico zinco, uma maior quantidade de valores em não conformidade ao padrão de qualidade da CONAMA 357/05, classe I, tabela 8 , inclusive com um pico de 0,295 $\mathrm{mg} / \mathrm{L}$ no ponto EDS3, para a área antrópica agrícola, comparada à área de estudo protegida por mata ciliar. Essa observação não é válida quando os dados são comparados pela média de cada área, onde os valores médios da área protegida por mata ciliar se apresentam muito próximos aos valores da área antrópica agrícola, mas na média se apresentam abaixo do padrão de qualidade do CONAMA 357/05, classe I e também do ponto denominado de referência. Segundo Alloway et al. (1997), o zinco é um dos elementos químicos importantes provindos de fontes agrícolas, utilizado como base de defensivos, e também como micronutriente em aditivos agrícolas e em rações na criação de animais.

Para o elemento químico fósforo, apresentado nas tabelas 5, 6 e 7 e gráficos 26 e 27, demonstra-se que grande parte dos valores se apresentaram em não conformidade com o padrão de qualidade da CONAMA 357/05, classe I, tabela 8 , mas abaixo dos valores médios do ponto de referência. É evidente também, que o maior pico de 0,370 mg/L no ponto EDS4 desse elemento químico, está presente na área de estudo denominada antrópica agrícola. Essa observação também é válida quando os dados que são comparados pela média de cada área. Devido à 
fertilização do solo e carreamento desse macronutriente para o corpo hídrico, na área sem proteção de mata ciliar. Pode-se inferir também, a possibilidade de a vegetação da mata ciliar filtrar e reter em suas raízes esse macronutriente.

As avaliações realizadas na água indicaram que há diferença entre a área antrópica agrícola e a área protegida por mata ciliar. Deste modo através dos parâmetros físico-químicos analisados no reservatório de Biritiba-Mirim (SP), fica evidente que estão ocorrendo alterações antrópicas nestes locais, confirmados pela baixa concentração de $\mathrm{OD}$ e pH na área antrópica agrícola (o que sugere excesso de matéria orgânica, inclusive possível entrada por origem antrópica, e decomposição destes produtos e consumo do oxigênio gerando acidez da água), possivelmente em razão do uso e ocupação inadequada no entorno do reservatório.

As atividades agrícolas e utilização de agroquímicos próxima ao reservatório, associado principalmente a geologia compreendida pelo Complexo Embu, com solos constituídos dominantemente por argila, como descrito em diversos trabalhos de determinação de porosidade e permeabilidade (REBOUÇAS; BRAGA; TUNDISI; 1999) dificultam a infiltração da água no aquífero dessas áreas, mas fixa estes elementos, que ao sofrerem lixiviação, as argilas vão se agregar aos sedimentos depositados no reservatório, podendo ser essa uma das fontes prováveis de comprometimento ambiental do sistema aquoso. Também é possível a existência de tendência ao comprometimento da qualidade ambiental a entrada de produtos de origem doméstica, ainda não identificada em função da ocupação irregular de área.

\subsection{Discussão referente aos elementos químicos encontrados nos sedimentos de fundo}

As determinações dos elementos químicos $\mathrm{Al}, \mathrm{Ca}, \mathrm{Fe}, \mathrm{Mg}, \mathrm{Na}, \mathrm{Zn}$ e $\mathrm{P}$ para os sedimentos de fundo, foram as mesmas determinações realizadas para água, que 
tiveram como objetivo uma avaliação mais precisa para esses elementos nos dois compartimentos, água e sedimentos de fundo. Essas determinações também revelam variações significativas nos pontos monitorados do reservatório de BiritibaMirim (SP) e a influência do uso e ocupação por atividade agrícola e da preservação da mata ciliar no seu entorno e o impacto na qualidade dos sedimentos de fundo, levando em consideração também, as características litológicas da área de estudo, quando possível.

Segundo Jesus et. al, (2004), os efluentes agrícolas permitem que os sistemas aquáticos se apresentem como fontes de conhecimento para pesquisa de poluição. Conforme descrito por Hortellani et. al, (2008), os efluentes agrícolas são fontes de poluição e ou contaminação para os sedimentos de fundo.

Dos elementos químicos analisados nos sedimentos de fundo e apresentados nas tabelas 9, 10 e 11, apenas Zinco e Fósforo estão presentes na tabela 12 (valores máximos permitidos): CETESB (2011) - TEL e PEL - Padrões de Qualidade, CETESB/2014 - Valores Orientadores para Solo e CONAMA 454/2012 - Valores para Sedimento de Material Dragado.

Semelhante aos resultados analíticos dos elementos químicos da água, conforme demonstrado nas tabelas 9,10 e 11 e gráficos 28 e 29, o parâmetro alumínio apresentou-se com valores superiores nos sedimentos de fundo na área denominada antrópica agrícola, comparada com a área com proteção de mata ciliar, inclusive com um pico de $336.000 \mathrm{mg} / \mathrm{kg}$, no ponto EDS3. Essa observação também é válida quando os dados são comparados pela média de cada área. Segundo Cavalcanti (2002), a bacia hidrográfica de Biritiba-Mirim (SP) situa-se sobre solos ricos em alumínio, destacando também as atividades agrícolas, silvicultura e pastagens. De modo análogo Silva (2013), encontrou relações similares às 
observadas nessa dissertação e explicam ser essa ocorrência resultado do escoamento de partículas contendo esse metal aderido a argilominerais, e ou aos agroquímicos utilizados pelos agricultores da região. É importante salientar que, mesmo esse elemento químico ocorrendo naturalmente nos solos da bacia hidrográfica, fica evidente a atuação da barreira filtro propiciada pela vegetação ciliar.

A mesma avaliação ocorre para os elementos químicos cálcio, ferro, magnésio, sódio, zinco e fósforo (tabelas 9, 10 e 11 e gráficos 30 a 41), onde na área denominada protegida por mata ciliar, grande parte dos valores é inferior aos da área denominada antrópica agrícola. Segundo Alloway et al. (1997), o zinco é um dos elementos químicos importantes provindos de fontes agrícolas, utilizado como base de defensivos e também como micronutriente em aditivos agrícolas e em rações na criação de animais. Conforme tabelas 9, 10, 11, 12 e gráficos 38 e 39, diferente do que ocorreu no compartimento água, esse elemento se apresentou com valores muito mais elevados nos sedimentos de fundo na área denominada antrópica agrícola, inclusive com dois picos que ultrapassaram os valores orientadores da CETESB/2014 e um pico que ultrapassou a resolução CONAMA 454/2012 e CETESB/2011 - TEL e PEL. Isso provavelmente devido à adsorção desse elemento com a partícula de solo e pela maior estabilidade do sedimento em relação à água. Quando os dados são comparados pela média de cada área, fica evidente os valores menores na área protegida por mata ciliar. Pela média também, observa-se que as duas áreas: protegida por mata ciliar e antrópica agrícola, se apresentaram com valores abaixo das normativas estabelecidas na tabela 12.

Segundo Cavalcanti (2002), a bacia hidrográfica de Biritiba-Mirim (SP) também se situa sobre solos ricos em ferro, e mais uma vez fica evidente a atuação 
da barreira filtro propiciada pela vegetação ciliar (tabelas 9, 10 e 11 e gráficos 32 e 33).

Destaca-se o parâmetro fósforo, onde na área denominada antrópica agrícola, todos os valores, inclusive com picos, nos pontos EDS1, EDS3 e EDS5, se apresentaram muito mais elevados dos analisados para a área protegida por mata ciliar e ponto de referência, até mesmo ultrapassando os valores de alerta da resolução CONAMA 454/2012. Essa observação também é válida quando os dados são comparados pela média de cada área (tabelas 9, 10, 11, 12 e gráficos 40 e 41). Provavelmente devido à fertilização do solo e carreamento desse macronutriente para o corpo hídrico, na área sem proteção de mata ciliar. Pode-se inferir também, a possibilidade de a vegetação da mata ciliar filtrar e reter em suas raízes esse macronutriente. Segundo Oliveira et al. (2010), a maior concentração de fósforo no sedimento de fundo pode ter relação com a ocorrência de erosão, carreando de sedimentos, nutrientes e elementos da área cultivada, como a adubação fosfatada, que é realizada a cada plantio, para o interior do corpo hídrico.

As avaliações realizadas nos sedimentos de fundo foram muito semelhantes às realizadas para água e também indicaram que há diferença entre a área antrópica agrícola e a área protegida por mata ciliar. Deste modo através dos parâmetros físico-químicos analisados no reservatório de Biritiba-Mirim (SP) fica evidente que está ocorrendo alterações antrópicas nestes locais. 


\section{CONCLUSÃO}

Conforme fica claro nos resultados apresentados, é significativa a importância da proteção dada pela mata ciliar no Reservatório de Biritiba-Mirim (SP).

Nas avaliações e discussão dos resultados do monitoramento ambiental na área de estudo onde a atividade antrópica agrícola é caracterizada pela ausência de mata ciliar, determinados compostos derivados das características do solo, do uso de fertilizantes e defensivos agrícolas nos sedimentos de fundo e água, se apresentaram com valores superiores aos da área de estudo da área do reservatório protegida por mata ciliar, em função do carreamento intenso de partículas, através das águas de escoamento tanto pluvial como de irrigação, para o interior do Reservatório de Biritiba-Mirim (SP).

A porção leste do reservatório de Biritiba-Mirim (SP) apresenta diferenças significativas para os parâmetros avaliados entre a área antrópica agrícola e a área protegida por mata ciliar.

As concentrações de $\mathrm{pH}$ e OD na área com atividade agrícola pode estar indicando intervenção antrópica associada à poluição. A precipitação atípica no período da coleta pode ter influenciado o resultado da condutividade elétrica nas áreas de estudo, a diferença entre as áreas pode ter sido determinada pela barreira de proteção contra o carreamento de sais exercida pela área protegida por mata ciliar.

As águas represadas no reservatório de Biritiba-Mirim (SP) podem justificar a diferença encontrada entre a temperatura no ponto referência (águas lóticas), quando comparada com as áreas estudadas em ambiente lêntico. A diferença média de $0,5^{\circ} \mathrm{C}$, entre a área antrópica agrícola e a área protegida por mata ciliar, também 
pode ter sido determinada pela maior estabilidade térmica da área protegida por mata ciliar nas margens do reservatório.

A diferença nas concentrações encontradas para alumínio e ferro, cujos solos são ricos desse elemento no Complexo Embu e consequentemente na bacia hidrográfica de Biritiba-Mirim (SP), entre a área antrópica agrícola e a área protegida por mata ciliar, pode ter sido determinada, principalmente, pelo carreamento de partículas, através das águas de escoamento para o sistema aquático, evidenciando a significativa importância da proteção dada pela mata ciliar no Reservatório de Biritiba-Mirim (SP).

Os resultados apresentados para os elementos químicos $\mathrm{Ca}, \mathrm{Mg}, \mathrm{Na}, \mathrm{Zn}$ e $\mathrm{P}$, tanto para água como para sedimento de fundo, também apresentam diferenças significativas, entre a área protegida por mata ciliar e a área com alguma ação antrópica agrícola. Essa observação também é válida quando os dados são comparados pela média de cada área de estudo. Isso evidencia, mesmo que alguns elementos químicos estejam presentes na composição do solo do Complexo Embu, nos agroquímicos e também em menor concentração na área protegida por mata ciliar, a importância desse estudo. É fato que a vegetação ciliar retém estes materiais em corpos de água, e é também consenso que sua conservação contém as ribanceiras de rios, diminui e filtra o escoamento superficial, e dificulta o carreamento de sedimentos e possíveis poluentes para os corpos hídricos.

Conforme descreve Chaves (2009), as matas ciliares também são essenciais para conservação da biodiversidade, servindo também como habitat e pelo motivo de muitas espécies de animais e microrganismos sobreviverem e dependerem diretamente dela e de sua conservação. 
Segundo Wang et al. (2005), quanto mais degradada se apresenta a mata ciliar, sua eficiência diminui em reter sedimentos, isso devido à redução da capacidade de amortizar a velocidade de condução de partículas transportadas pela enxurrada em eventos de erosão hídrica, essas partículas não são retidas de modo eficiente pela vegetação ripária, contribuindo para um menor controle hidrológico. $\mathrm{O}$ que corrobora de modo muito significativo com todos os dados observados e apresentados nessa dissertação.

Nessa dissertação buscou-se demonstrar a preocupação do ponto de vista ambiental, que visa melhorar a qualidade de vida da população, a qualidade ambiental das áreas degradadas, a qualidade e quantidade da água deste e de outros mananciais, e corrobora e subsidia futuras propostas de políticas públicas e ações da sociedade para uma melhor gestão dos processos de uso e ocupação do solo, alertando para a importância das matas ciliares e sua manutenção e ou restauração ecológica no entorno dos cursos d'água, sempre visando à melhoria de sua qualidade e a preservação da biodiversidade, bem como dos reservatórios constituídos com finalidade de abastecimento público. 


\section{RECOMENDAÇÕES}

A utilização do compartimento sedimentos de fundo nas avaliações da qualidade dos ecossistemas aquáticos tem sido utilizado pela CETESB, mas apenas em alguns pontos de monitoramento, aparentemente considerados mais críticos e priorizados pela agência ambiental. No Sistema Alto Tietê, apenas no Reservatório de Ponte Nova há um ponto de monitoramento para sedimentos de fundo. No Reservatório de Biritiba-Mirim (SP) não há nenhum ponto de monitoramento, portanto, não há histórico para que fosse possível comparar com os pontos monitorados nesta dissertação. É importante retratar que o monitoramento, a sua representatividade e o histórico de influência de atividades antrópicas sobre esses ambientes aquáticos, nem sempre são detectáveis pelo uso de variáveis ambientais no compartimento água.

Fica aqui registrado aos órgãos gestores de reservatórios para abastecimento público, que as matas ciliares representam muitos benefícios para os corpos hídricos, reforçando ainda os já citados nessa dissertação, pois contribui, para manutenção dos habitats, para o fluxo gênico, para o equilíbrio térmico da água, reduzindo os extremos de temperatura e mantendo a oxigenação do meio aquático. Promove, também, restabelecimento da estrutura e das condições de aeração, retenção de água, o que aumenta a infiltração, deixando o solo mais úmido. Um indivíduo arbóreo, produz em média, através do mecanismo da evapotranspiração, aproximadamente 400 litros de água por dia, formando os chamados "rios aéreos".

Diminui também o escoamento e os riscos de erosão, aumenta a absorção de nutrientes pelos indivíduos arbóreos, arbustivos e plantas herbáceas, minimizando a lixiviação excessiva dos sais minerais do solo para os corpos hídricos. 
É importante salientar que o Decreto Estadual ํㅜ 60.521/2014, que instituiu o Programa de Incentivos à Recuperação de Matas Ciliares e à Recomposição de Vegetação nas Bacias Formadoras de Mananciais de Água - Programa Mata Ciliar, tem o objetivo de ampliar a proteção e conservação dos recursos hídricos e da biodiversidade, por meio da otimização e direcionamento de investimentos públicos e privados para: a proteção e recuperação de matas ciliares, nascentes e olhos d'água, a proteção de áreas de recarga de aquífero, a ampliação da cobertura de vegetação nativa em mananciais, especialmente a montante de pontos de captação para abastecimento público, os plantios de árvores nativas e melhoria do manejo de sistemas produtivos em bacias formadoras de mananciais de água. E também através da resolução conjunta SMA/SSRH no 001/2014, que definiu as áreas de intervenção que trata esse programa, onde o reservatório de Biritiba-Mirim (SP), que pertence ao Sistema Produtor - Alto Tietê, com uma área beneficiada de 2.000 ha, se encontra comtemplado.

A manutenção e ou a restauração ecológica das matas ciliares, são ações fundamentais para proteção dos reservatórios utilizados para abastecimento público, culminado no aumento da oferta e na melhoria da qualidade da água para consumo humano. 


\section{REFERÊNCIAS BIBLIOGRÁFICAS}

ALLOWAY, B. J.; AYRES, D. C. 1997. Chemical Principles of Environmental Pollution, 2 ed. Ed. Chapman \& Hall, New York.

AMAZARRAY, M. T. R. A importância do estudo das formas de transporte e de transferência de elementos-traço para a avaliação ecotoxicológica. In: ENCONTRO DE ECOTOXICOLOGIA, II, 1992. Rio Grande. Anais... Rio Grande: Universidade Federal de Rio Grande, 1992.

APHA (American Public Heath Association). Standard methods for the examination of water and wastewater. Washington, DC, 2012.

BEVILACQUA, J. E. Estudos Sobre a Caracterização e a Estabilidade de amostras de Sedimento do Rio Tietê - SP, 1996. Dissertação (Doutorado) - Instituto de Química da Universidade de São Paulo, São Paulo.

BICUDO, C.E.M.; RAMÍREZ, R.J.J.; TUCCI, A.; BICUDO, D.C. Dinâmica de populações fitoplanctônicas em ambiente eutrofizado: O Lago das Garças, São Paulo. In: HENRY, R. (org.) Ecologia de reservatórios: Estrutura, função e aspectos sociais. Botucatu: FAPESP / FUNDIBIO. 1999. p.449-508.

BRAGA, Benedito; REBOUÇAS, Aldo da C.; TUNDISI, José G. Águas doces no Brasil: capital ecológico, uso e conservação. Águas doces no Brasil: capital ecológico, uso e conservação. Ed Escrituras, 4ª̣edição, 2006.

BRANCO, S.M. Hidrologia aplicada à engenharia sanitária. 3.ed. São Paulo: CETESB/ ASCETESB, 1986. 616 p.

BRANCO, S. M. Água, meio ambiente e saúde. In: REBOUÇAS, A. C.; BRAGA, B.; TUNDISI, J. G. Águas doces no Brasil: capital ecológico, uso e conservação. São Paulo: Escrituras. São Paulo: Escrituras, 2002, p. 227-248.

BRASIL. Lei $n^{0}$ 7.802, de 11 de Julho de 1989. Dispõe sobre a pesquisa, a experimentação, a produção, a embalagem e rotulagem, o transporte, 0 armazenamento, a comercialização, a propaganda comercial, a utilização, a importação, a exportação, o destino final dos resíduos e embalagens, o registro, a classificação, o controle, a inspeção e a fiscalização de agrotóxicos, seus componentes e afins, e dá outras providências. Diário Oficial da União, p. 11459. 12 jul. 1989. Seção 1.

BRASIL. Lei $n^{0} 12.651$, de 25 de maio de 2012. Dispõe sobre a proteção da vegetação nativa; altera as Leis nos 6.938, de 31 de agosto de 1981, 9.393, de 19 
de dezembro de 1996, e 11.428, de 22 de dezembro de 2006; revoga as Leis nos 4.771, de 15 de setembro de 1965, e 7.754, de 14 de abril de 1989, e a Medida Provisória no 2.166-67, de 24 de agosto de 2001; e dá outras providências. Disponível em: <http://www.planalto.gov.br/ccivil_03/_ato20112014/2012/lei/l12651.htm>. Acesso em: 06 abr. 2015.

BRITISH COLUMBIA. Guidelines for interpreting Water Quality Data: Versão 1.0. 1998. Disponível em: <https://www.for.gov.bc.ca/hts/risc/pubs/aquatic/interp/intrptoc.htm>. Acesso em: 10 out. 2014.

CALVERT, S.E. The mineralogy and geochemistry of near-shore sediments. Chemical Oceanography. Academic Press, New York, v. 6, pp. 187-280, 1976.

CARVALHO, F.M.; TAVARES, T.M. Avaliação da exposição de populações humanas a metais pesados no ambiente: exemplos no recôncavo baiano. Química Nova, São Paulo, v. 5, p. 147-153, 1992.

CAVALCANTI, Malva Andrea Mancuso Paraiso. A modelagem matemática associada ao sistema de informação geográfica como instrumento de previsão no estudo do impacto hidrogeológico de reservatórios. 2002. Tese (Doutorado) Instituto de Geociências, Universidade de São Paulo. São Paulo, 2002. Disponível em: <http://www.teses.usp.br/teses/disponiveis/44/44133/tde-31012003-081603/ptbr.php>. Acesso em: 23 nov. 2014.

CAVENAGHI, A.L.; VELINI, E.D.; GALO, M.L.B.T.; CARVALHO, F.T.; NEGRISOLI, E.; TRINDADE, M.L.B.; SIMIONATO, J.L.A. Caracterização da qualidade de água e sedimento relacionados com a ocorrência de plantas aquáticas em cinco reservatórios da bacia do rio Tietê. Planta Daninha, Viçosa, 21(Ed. Especial):43-52. 2003.

CBH-AT - Comitê da Bacia Hidrográfica do Alto Tietê. Fundação Universidade de São Paulo (FUSP). Plano da Bacia do Alto Tietê - Relatório Síntese. São Paulo: FUSP, 2001.

CEPAGRI - Centro de Pesquisas Meterológicas e Climáticas Aplicadas a Agricultura. A classificação climática de Koeppen para o Estado de São Paulo. Disponível em: <http://www.cpa.unicamp.br/outras-informacoes/clima-dosmunicipios-paulistas.html>. Acesso em: 10 nov. 2015.

CETESB - Companhia Ambiental do Estado de São Paulo - Relatório de Qualidade das águas interiores do Estado de São Paulo: relatório técnico. São Paulo: CETESB, 1999. 
CETESB - Companhia Ambiental do Estado de São Paulo. Decisão de Diretoria no 045/2014/E/C/l, de 20 de fevereiro de 2014. Publicada no DOU no 045, de 20/02/2014, p. 53 - Valores Orientadores para Solos e Águas Subterrâneas no Estado de São Paulo - 2014, em substituição aos Valores Orientadores de 2005.

CETESB - Companhia Ambiental do Estado de São Paulo. Qualidade das águas superficiais no estado de São Paulo 2010 [recurso eletrônico] / CETESB. - - São Paulo: CETESB, 2011. 298 p.: il. color. + apêndice B.

CETESB - Companhia Ambiental do Estado de São Paulo. Disponível em: http://aguasinteriores.CETESB.sp.gov.br/wpcontent/uploads/sites/32/2013/11/10.pdf. Acesso em: 06 mar. 2015.

CETESB - Companhia de Tecnologia Ambiental do estado de São Paulo; ANA Agência Nacional de Águas. Guia nacional de coleta e preservação de amostras: água, sedimento, comunidades aquáticas e efluentes líquidos. Brasília: 2011. Disponível em: http://arquivos.ana.gov.br/institucional/sge/CEDOC/Catalogo/2012/GuiaNacionalDeC oleta.pdf>.

CETESB - Companhia Ambiental do Estado de São Paulo. Relatório de Qualidade das Águas Interiores do Estado de São Paulo 2013. São Paulo: CETESB, 2014. Disponível em: < http://aguasinteriores.CETESB.sp.gov.br/publicacoes-erelatorios/>. Acesso em: 10 out. 2014.

CHAPMAN, D. Water quality assessments. A guide to use of biota, sediments and water in environmental monitoring. Ed. Chapman, D. Chapman e Hall. Cambridge: Unesco/WHO/UNEP, 1992.585p.

CHAPMAN, D.. Water quality assessments. A guide to use of biota, sediments and water in environmental monitoring. Cambridge: 1992. 585p.

CHAVES, A. Importância da mata ciliar (legislação) na proteção dos cursos hídricos, alternativas para sua viabilização em Pequenas propriedades rurais. IN: SEMINÁRIO APRESENTADO NA DISCIPLINA "MANEJO E CONSERVAÇÃO DO SOLO E DA ÁGUA. Universidade de Passo Fundo. 2009.

CONAMA - Conselho Nacional do Meio Ambiente. Resolução no 454, de 01 de novembro de 2012. Estabelece as diretrizes gerais e os procedimentos referenciais para o gerenciamento do material a ser dragado em águas sob jurisdição nacional. Disponível em: < http://www.mma.gov.br/port/conama/legiabre.cfm?codlegi=693>. Acesso em: 06 abr. 2015. 
CONAMA - Conselho Nacional do Meio Ambiente. Resolução no 10, de 1 de outubro de 1993. Estabelece os parâmetros básicos para análise dos estágios de sucessão de Mata Atlântica. Publicada no DOU no 209, de 3 de novembro de 1993, Seção 1, páginas 16497-16498

CONAMA - Conselho Nacional de Meio Ambiente. Resolução $n^{\circ} 357$ de 17 de março de 2005. Dispõe sobre a classificação dos corpos de água e diretrizes ambientais para o seu enquadramento, bem como estabelece as condições e padrões de lançamento de efluentes, e dá outras providências. Disponível em: < http://www.mma.gov.br/port/conama/legiabre.cfm?codlegi=459>. Acesso em: 25 mar. 2015.

CONCEIÇÃO, F. T.; BONOTTO, D. M. Relações hidroquímicas aplicadas na avaliação da qualidade da água e diagnóstico ambiental na bacia do Rio Corumbataí (SP). Geochimica Brasiliensis, v. 16, n. 1, p. 1-21, 2002.

COOKE, G.D.; WELCH, E.B; PETERSON, S.A.; NICHOLS, S.A. Restoration and management lakes and reservoirs. Boca Raton, FL: CRC Press, 2005. 584p.

CPRM - Companhia de Pesquisa de Recursos Minerais. Programa levantamentos geológicos do Brasil: Carta geológica. Pedreira, A. J.; Martins Martagalho, R. de S. F. X. (org). Brasília: DNPM/CPRM, 1990. 122p, Escala 1:100.000.

DAEE - Departamento de Águas e Energia Elétrica do Estado de São Paulo. Estudo de Impacto Ambiental - Sistema Produtor do Alto Tietê: Barragens de Bititiba-Mirim, Paraitinga e Complementação Taiaçupeba. CCN Planejamento. São Paulo - SP, 1997.

DAEE - Departamento de Águas e Energia Elétrica do Estado de São Paulo. Estudo de Águas Subterrâneas, Região Administrativa 1 - Grande São Paulo. vol. 1 Resumo. 220p. SOMA. São Paulo - SP, 1975

DAEE - Departamento de Águas e Energia Elétrica. Plano Estadual de Recursos Hídricos: 2004/2007. São Paulo: DAEE, Relatório Técnico, p. 92. 2006.

DAEE - Departamento de Águas e Energia Elétrica. Sistema Produtor Alto Tietê, 2011. Disponível em: <http://www.daee.sp.gov.br/>. Acesso em: 06 abr. 2015.

DAEE - - Departamento de Águas e Energia Elétrica. 2015. Desenho esquemático Sistema Alto Tietê. Disponível em: <http://www.daee.sp.gov.br/images/stories/noticias/2012/janeiro/sistema/sistemaaltot iete19jan2012.jpg >. Acesso em: 20 mar. 2015. 
DORES, E. F. G. C.; DE-LAMONICA-FREIRE, E. M. Contaminação de ambiente aquático por pesticidas: vias de contaminação e dinâmica dos pesticidas no ambiente aquático. Pesticidas: Revista de Ecotoxicologia e Meio Ambiente, Curitiba, v. 9, p. 1-18, 1999.

EMBRAPA - Empresa Brasileira de Pesquisa Agropecuária. Centro Nacional de Pesquisa de Florestas. Aspectos Ecológicos. Disponível em: <http://www.cnpf.embrapa.br/pesquisa/efb/aspec.htm>. Acesso em: 14 nov. 2014.

EMPLASA - Empresa Paulista de Planejamento Metropolitano S.A. Cartas Topográficas. 1996.

ENZWEILER, J. Amostragem de águas e parâmetros de qualidade. GE117, 2010. Disponível em: <http://www.ige.unicamp.br/site/aulas/9/Aula5.pdfn>. Acesso em: 10 out. 2014.

ESTEVES, F. A. Fundamentos de Limnologia. Rio de Janeiro: Interciência, 1998, $602 p$;

ESTEVES, F. A. Fundamentals of limnology. Rio de Janeiro: Interciência LTDA, 2011.

FADIGAS F. S; AMARAL-SOBRINHO, N. M. B.; MAZUR, N.; ANJOS, L. H. C. A., FREIXO, A.A. Concentrações naturais de metais pesados em algumas classes de solos brasileiros. Bragantia, Campinas, v. 61, n. 2, p. 151-159, 2002. Disponível

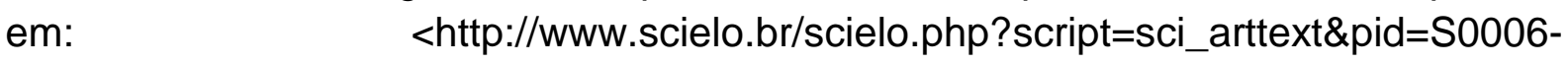
$87052002000200008 \&$ Ing=en\&nrm=iso $>$. Acesso em 02 Set 2015.

FARIA, L. C. Mapa de Desapropriação - Reservatório de Biritiba-Mirim, Mosaico de Ortofotos. DAEE, 2008. 1:10.000.

FATMA - Fundação do Meio Ambiente. Relevância dos parâmetros de qualidade de água aplicados a águas correntes. Parte I: características gerais, nutrientes, elementos traço e substâncias nocivas e inorgânicas, características biológicas. Florianópolis: Fundação de Meio Ambiente de Santa Catarina, 1999.

FERREIRA, A. C.; ROCHA, L. C.; FIGUEIREDO, M.do A. Análise do Índice De Qualidade de Água na Bacia do Córrego do Rio Acima, São João Del-Rei/MG. Revista Nacional de Gerenciamento de Cidades, v. 3, n. 15, 2015. 
FIA - Fundação Instituto de Administração. Disponível em: $<$ http://www.fundacaofia.com.br/gdusm/sub_bacia_at.htm>. Acesso em: 20 mar. 2015.

FORSTNER, U; WITTMANN, G. T. W. Metal Polluition in the Aquatic Environment. 1. ed. Heidelberg: Springer Verlag, 486p, 1981.

FORSTNER, U. Metal concentrations in freshwater-sediments-natural background and cultural effects. In: GOLTERMAN, H.L. (Ed.), Interations Between Sediments and Fresh Water., The Hague: 1977, pp. 94-103.

FRANCO, T.; DRUCK, G. Padrões de industrialização, riscos e meio ambiente. Ciência e Saúde Coletiva, Rio de Janeiro, v. 3, n. 2, p. 61-71, 1998.

GOULART, M. D.; CALLISTO, Marcos. Bioindicadores de qualidade de água como ferramenta em estudos de impacto ambiental. Revista da FAPAM, v. 2, n. 1, p. 156164, 2003.

HART, B. T. Uptake of trace metals by sediments and suspended particulates: A review. Hydrobiology, v. 91, n. 1, pp. 299-313, 1982.

HASUI Y, DANTAS ASL, CARNEIRO CDR e BISTRICH CA. O embasamento précambriano e eopaleozóico em São Paulo. Instituto de Pesquisas Tecnológicas de São Paulo. Mapa Geológico do Estado de São Paulo, Escala 1:500.000, v. 1, n. 000, p. 12-45, 1981.

HENRY, R.; NUNES, M.A.; MITSUKA, P.M.; LIMA, N.; CASANOVA, S.M.C. Variação espacial e temporal da produtividade primária pelo fitoplâncton na represa de Jurumirim (rio Paranapanema, SP). Rev. Brasil. Biol., São Carlos, 58(4): 571-590. 1998.

HORTELLANI, M. A; JORGE, E. S. S; ABESSA, D. M. S; SOUSA, E. C. P. M. Avaliação da contaminação por elementos metálicos dos sedimentos do estuário Santos - São Vicente. Química Nova, v. 31, n.1, pp. 10-19, 2008.

IBGE - Instituto Brasileiro de Geografia e Estatística. Disponível em: <http://cod.ibge.gov.br/8EW>. Acesso em: 23 nov. 2014.

ISA - Instituto Sócioambiental. Seminário Guarapiranga (1.:2006:São Paulo) Proposição de ações prioritárias para garantir água de boa qualidade para abastecimento público / [organizadoras Marussia Whately e Pilar Cunha]. São Paulo: Instituto Socioambiental, 2006. 
IZAZOLA, H.; DO CARMO, R. L. México e São Paulo: expansão metropolitana, desigualdade social e a questão da água. In: I CONGRESSO DA ASSOCIAÇÃO LATINO AMERICANA DE ESTUDOS DE POPULAÇÃO, 2004, Caxambu - MG, Brasil. Disponível em: < http://www.abep.nepo.unicamp.br/site_eventos_alap/pdf/alap2004_258.pdf>. Acesso em: 16 mar. 2015.

JESUS, H. C; COSTA, E. A: MENDONÇA, A. S. F; ZANDONALE, E. Distribuição de metais pesados em sedimentos do sistema estuarino a ilha de Vitória - ES. Química Nova, v. 27, n. 3, p. 378-386, 2004.

JORCIN, A. (org.). Ecologia de reservatórios: Impactos potenciais, ações de manejo e sistemas em cascata. São Carlos: RiMa. p.417-434.

KRUMGALZ B.S. Unusal grain size effect on trace metals and organic matter in contaminated sediments. Marine Pollution Bulletin, v. 20, pp. 608-611, 1989.

KRUMGALZ, B. S., FAINSHTEIN, G. and COHEN, A. Grain size effect on anthropogenic trace metal and organic matter distribution in marine sediments, Science of the Total Environment, Elsevier Science Publishers, v. 116, pp. 15-30, 1992.

KRUPEK, R A.; FELSKI, G. Avaliação da Cobertura Ripária de Rios e Riachos da Bacia Hidrográfica do Rio das Pedras, Região Centro-Sul do Estado do Paraná. Revista Ciências Exatas e Naturais, v.8, n.2, p. 179-188, 2006.

LAMPARELLI, M. C. Grau de trofia em corpos d'água do estado de São Paulo: avaliação dos métodos de monitoramento. 2004. 238f. Tese (Doutorado) - Instituto de Biociências - Universidade de São Paulo, São Paulo, 2004.

LEMES, M. J. de L. Avaliação de metais e elementos-traço em águas e sedimentos das Bacias Hidrográficas dos rio Mogi-Guaçu e Pardo, São Paulo. 2001. 248 f. Dissertação (Mestrado), Instituto de Pesquisas Energética e Nucleares, Universidade de São Paulo, 2001.

LIMA, W. P.; ZAKIA, M. J. B. Hidrologia de matas ciliares. Matas Ciliares: conservação e recuperação. Edusp, São Paulo, p. 33-44, 2000.

LOMBA, C. C. P. A Escassez Hídrica na Região Metropolitana de São Paulo. In: CRISE, PRÁXIS E AUTONOMIA: ESPAÇOS DE RESISTÊNCIA E DE ESPERANÇAS - ESPAÇO DE SOCIALIZAÇÃO DE COLETIVOS, 2010, Porto Alegre - RS. Anais XVI Encontro Nacional dos Geógrafos A Escassez Hídrica na 
Região Metropolitana de São Paulo. Porto Alegre: AGB, 2010. Disponível em: <www.agb.org.br/>. Acesso em: 24 mar. 2015.

MAPEIA. Sistema de Visualização de Dados da EMPLASA (Empresa Paulista de Planejamento Metropolitano S.A.). Disponível em: http://www.mapeiasp.sp.gov.br/Mapa - EmplasaGeo. Acesso em 14 mar. 2014.

MARTINS, S. V. Recuperação de matas ciliares. $2^{\mathrm{a}}$ Ed. Revista e ampliada. Viçosa: Editora Aprenda Fácil, 2007. 255p.

MCNEELY, R. N.; NEIMANIS, V. P.; DWYER, L.,.. Water Quality Sourcebook: A Guide to Water Quality Parameters. Ottawa, Canadá: 1979. 89 p.

MMA - Ministério do Meio ambiente. Agrotóxicos. Disponível em: <http://www.mma.gov.br/seguranca-quimica/agrotoxicos>. Acesso em 10 Set. 2015.

MOCELLIN, Onir. Determinação do Nível de Risco Público ao Banho de Mar das Praias Arenosas do Litoral Centro Norte de Santa Catarina. Dissertação (Mestrado) Univali, 2006.

MOORE, J. W.; RAMAMOORTHY, S. Heavy Metals in Natural Waters. 1. ed. New York: Springer Verlag, 268p. 1984.

MUDROCK A AND MACKNIGHT SD. CRC Handbook of techniques for aquatic sediment sampling. Boca Raton: CRC Press Inc, Ann Arbor. 1991, 210p.

MURILLO, E. O Sistema Produtor do Alto Tietê: Um Estudo Toponímico. 2008. Dissertação (Mestrado) - Faculdade de Filosofia, Letras e Ciências Humanas, Universidade de São Paulo. São Paulo, 2008. Disponível em: <http://www.teses.usp.br/teses/disponiveis/8/8139/tde-25112009-092857/pt-br.php>. Acesso em: 23 nov. 2014.

NÚÑEZ, J. E. V; SOBRINHO, N. M. B; MAZUR, N. Consequências de diferentes sistemas de preparo do solo sobre a contaminação do solo, sedimentos e água por metais pesados. Edafologia, v. 13, pp. 73-85, 2006. Disponível em: <http://www.edafologia.net/revista/tomo13b/articulo73.pdf >. Acesso em: 6 abr. 2015.

OLIVEIRA, C. A; KLIEMANN, H. J.; CORRECHEL, V.; SANTOS, F. C. V. Avaliação da retenção de sedimentos pela vegetação ripária pela caracterização morfológica e físico-química do solo. Revista Brasileira de Engenharia Agrícola e Ambiental, v. 14, n. 12, p. 1281-1287, 2010. 
OLIVEIRA, C., LEAL, J.R., VELLOSO, A.C.X. Processos redox em glei húmico do Estado do Rio de Janeiro: IV. Variação no "status redox" (pe+pH) de solos cultivados com arroz alagado. Revista Brasileira de Ciência do solo, Campinas, v. 17, n.1, p. 35-39, 1993.

PAIVA, M. H. R. P.; PENEDO, S.; KUENNE, A.; PRADO, R. B.; SCHULER, A. E. Qualidade da Agua e Exportação de Sedimentos em Sub-bacias dos rios GuapiMacacu-Bioma Mata Atlântica-RJ. In: XXXIII CONGRESSO BRASILEIRO DE CIÊNCIA DO SOLO, 2011, Uberlândia, Minas Gerais - Brasil. Solos nos Biomas Brasileiros: Sustentabilidade e Mudanças Climáticas. Disponível em: <http://ainfo.cnptia.embrapa.br/digital/bitstream/item/51926/1/2315-1.pdf>. Acesso em: 06 abr. 2015.

PEREIRA, L. S. Evolução espaço - temporal do uso e cobertura da terra e qualidade da água do Ribeirão Piancó - Anápolis - Goiás, 2008. 98 f. Dissertação (Mestrado) Universidade Estadual de Goiás, 2008. Disponível em: < http://www.unucet.ueg.br/biblioteca/arquivos/DISSERTACAO_LYNE.pdf>. Acesso em: 06 abr. 2015.

PIRES NETO, A. G. As abordagens sintético-histórica e analítico-dinâmica: uma proposição metodológica para a geomorfologia. 1992. Tese (Doutorado) Faculdade de Filosofia, Letras e Ciências Humanas da Universidade de São Paulo, São Paulo, 1992.

PRADO, R. B.; NOVO, E. M. L. de M. Aplicação de geotecnologias na modelagem do potencial poluidor das sub-bacias de contribuição para o reservatório de Barra Bonita-SP relacionado à qualidade da água. In: SIMPÓSIO BRASILEIRO DE SENSORIAMENTO REMOTO, 2005, Goiânia - Brasil. Anais XII... Goiânia: INPE, 2005, p. 3253-3260. Disponível em <http://marte.sid.inpe.br/col/tid.inpe.br/sbsr/2005/02.12.16.31/doc/@sumario.htm>. Acesso em: 25 abr. 2015.

PRADO, R. P. Geotecnologias aplicadas à análise espaço temporal do uso e cobertura da terra e qualidade da água do reservatório de Barra Bonita, SP, como suporte à gestão de recursos hídricos. 2004. 158 f. Tese (Doutorado) - Escola de Engenharia de São Carlos, São Paulo, 2004.

PRAT, N.; MUNNÉ, A. Water use and quality and stream flow in a Mediterranean stream. Water Research, v. 34, n. 15, p. 3876-3881, 2000.

RANGEL, L. Conservar o solo para preservar a água e reduzir a fome. O Eco. 2015. Disponível em: <http://www.oeco.org.br/colunas/colunistas-convidados/29070- 
conservar-o-solo-para-preservar-a-agua-e-reduzir-a-fome/>. Acesso em 22 abr. 2015.

REBOUÇAS, A. da C.; BRAGA, B.; TUNDISI, J.G. - Águas Doces no Brasil: capital ecológico, uso e conservação. São Paulo: Escrituras Editora, 1999. 717p.

REBOUÇAS, A. Condições de Uso e Proteção das Águas Subterrâneas. In: SEMINÁRIO PROBLEMAS GEOLÓGICOS GEOTÉCNICOS NA REGIÃO METROPOLITANA DE SÃO PAULO, 1992, São Paulo. São Paulo: ABAS/ABGE/SBG-SP, 1992, p.77-88.

REBOUÇAS, A. C.; BRAGA, B.; TUNDISI, J. G. Águas doces no Brasil: capital ecológico, uso e conservação. 3 ed. São Paulo: Escrituras, 2006. 748p.

RIBEIRO, M. L.; LOURENCETTI, C.; PEREIRA, S. Y.; MARCHI, M. R. R. Contaminação de águas subterrâneas por pesticidas: avaliação preliminar. Química Nova, v. 30, n. 3, p. 688-694, 2007.

RIBEIRO, L.H.L.; KISHI, R.T.; ALBERTI, S.M.; BUBA, H.; BIZZONI, O.;OLIVEIRA, A.G.; MARENDA, P.A. Carga de nutrientes afluente ao reservatório da usina hidrelétrica de Salto Caxias (PR): um enfoque ao controle da eutrofização. In: SIMPÓSIO BRASILEIRO DE RECURSOS HÍDRICOS, 16, João Pessoa, 2024/nov./2005.

RODRIGUES, R. R. \& FILHO, H. L. Matas Ciliares: conservação e recuperação. São Paulo: EDUSP, 2004. p. 15-25

ROSS, J.L.S. \& MOROZ, I.C. Mapa Geomorfológico do Estado de São Paulo. São Paulo: Laboratório de Geomorfologia Depto de Geografia FFLCH-USP/Laboratório de Cartografia Geotécnica - Geologia Aplicada - IPT/FAPESP, 1997. 63p.

SABESP;CEPAS;IG-USP. Diagnóstico Hidrogeológico da Região Metropolitana de São Paulo. São Paulo: 1994,115p.

SANTOS, T. G.; SPIES, M. R.; KOPP, K.; TREVISAN, R.; CECHIN, S. Z. Mamíferos do campus da Universidade Federal de Santa Maria, Rio Grande do Sul, Brasil. Biota Neotrópica., v.8, n.1, jan./mar. 2008. Disponível em: <http://www.biotaneotropica.org.br/v8n1/pt/abstract?inventory+bn00508012008>. Acesso em: 06 abr. 2015.

SANTOS, D. G.; DOMINGOS, A. F.; GISLER, C. V. T.: Gestão de Recursos Hídricos na Agricultura: O Programa Produtor de Água. IN: Manejo e conservação da água no contexto e mudanças ambientais. XVII REUNIÃO BRASILEIRA DE MANEJO E 
CONSERVAÇÃO DO SOLO E DA ÁGUA. Rio de Janeiro: 10 a 15 de agosto de 2008.

SÃO PAULO. Secretaria de Agricultura e Abastecimento. Coordenadoria de Assistência Técnica Integral. Instituto de Economia Agrícola. Levantamento censitário de unidades de produção agrícola do Estado de São Paulo - LUPA. São Paulo: SAA/CATI/IEA, 2008. Disponível em: <http://www.cati.sp.gov.br/projetolupa>. Acesso em: 14 nov. 2014.

SÃO PAULO. Secretaria do Meio Ambiente. Instituto Florestal. Inventário Florestal da Vegetação Natural do Estado de São Paulo. São Paulo: 2005. Disponível em: <http://s.ambiente.sp.gov.br/sifesp/biritibamirim.pdf>. Acesso em: 14 nov. 2014.

SÃO PAULO. Resolução Conjunta SMA/IBAMA no 1, de 17 de fevereiro de 1994. Orientar os procedimentos de licenciamento de exploração da vegetação nativa no Estado de São Paulo. Disponível em: <http://www.CETESB.sp.gov.br/licenciamento/documentos/1994_Res_Conj_SMA_IB AMA_1.pdf>. Acesso em: 16 set. 2014.

SÃO PAULO. Decreto Estadual no 60.521 de 5 de junho de 2014. Institui o Programa de Incentivos à Recuperação de Matas Ciliares e à Recomposição de Vegetação nas Bacias Formadoras de Mananciais de Água, institui a unidade padrão ÁrvoreEquivalente e dá providências correlatas. Disponível em: < http://www.al.sp.gov.br/repositorio/legislacao/decreto/2014/decreto-6052105.06.2014.html>. Acesso em: 05 maio 2015.

SÃO PAULO. Resolução Conjunta SMA/SSRH 001, de 05 de junho de 2014. Define as áreas de intervenção do Programa de Incentivos à Recuperação de Matas Ciliares e à Recomposição de Vegetação nas Bacias Formadoras de Mananciais de Água - Programa Mata Ciliar. Disponível em: < http://www.ambiente.sp.gov.br/legislacao/files/2014/06/RESOLU\%C3\%87\%C\%83OCONJUNTA-SMA-SSRH-001-05062014.pdf>. Acesso em: 05 maio 2015.

SAUNDERS, D. L.; MEEUWIG, J. J.; VINCENT, A. C. J. Freshwater protected areas: strategies for conservation. Conservation Biology, Quebec, v.16, n.1, pp. 30-41, 2002. Disponível em: < http://onlinelibrary.wiley.com/doi/10.1046/j.15231739.2002.99562.x/epdf>. Acesso em: 23 mar. 2015.

SENDACZ, S.; MONTEIRO JUNIOR, A.J.; MERCANTE, C.T.J.; MENEZES, L.C.B.; MORAES, J.F. Sistemas em cascata: concentrações e cargas de nutrientes no Sistema Produtor Alto Tietê, São Paulo. In: NOGUEIRA, M. G.; HENRY, R e JORCIN, A. (org.). Ecologia de reservatórios: Impactos potenciais, ações de manejo e sistemas em cascata. São Carlos: RiMa, 2005, p.417-434. 
SENDACZ, S.; MONTEIRO JUNIOR, A.J.; MERCANTE, C.T.J.; MENEZES, L.C.B.; MORAES, J.F. Sistemas em cascata: concentrações e cargas de nutrientes no Sistema Produtor Alto Tietê. São Paulo, 2005. In: NOGUEIRA, M. G.; HENRY, R e

SMA - Secretaria de Meio Ambiente. Sistema Ambiental Paulista - Programa Nascentes - Proteção e restauração de mata ciliar. Disponível em: <http://www.ambiente.sp.gov.br/programanascentes/>. Acesso em: 06 abr. 2015.

SSRH - Secretaria de Saneamento e Recursos Hídricos. Programa Mananciais. Disponível

em: http://www.saneamento.sp.gov.br/site_manaciais/default.asp?ASP=introducao\&Parm =Apresentacao\#. Acesso em 20mar.2015.

SIGRH - Sistema Integrado de Gerenciamento de Recursos Hídricos do Estado de São Paulo. Disponível em: <http://www.sigrh.sp.gov.br/sigrh/ARQS/RELATORIO/CRH/1063/ugrhi_06_10.pdf.> Acesso em 15 set. 2015.

SILVA R.T; PORTO M. F. A. Gestão urbana e gestão das águas: caminhos da integração. Estudos avançados, v.17, n.47, São Paulo, Jan./Apr. 2003.

SILVA, D. F.; GALVÍNCIO, J. D.; ALMEIDA, H. R. R. C. Variabilidade da qualidade de água na bacia hidrográfica do rio São Francisco e atividades antrópicas relacionadas.Qualit@s Revista Eletrônica, v. 9, n.3, pp. 1-17, 2010.

SILVA, C. de L. Estudo da qualidade da água na sub-bacia do Ribeirão do Carmo (MG), com ênfase na geoquímica e na comunidade zooplanctônica [manuscrito] / Cláudia de Lima e Silva - 2013.

SOUZA, D. F. O assoreamento e a qualidade fisico-quimico das águas superficiais da lagoa maior em 2013/14 no Município de Três Lagoas/MS, 2015. Disponível em: < http://repositorio.cbc.ufms.br:8080/jspui/handle/123456789/2363>. Acesso em: 25 set. 2015.

STEINBLUMS, I.J.; FROELICH, H.A. ; LYONS, J.K.. Designing stable buffer strips for stream protection. Journal of Forestry, 82(1), 49-52, 1984.

STUMM, W.; MORGAN, J. J. Aquatic Chemistry. A Willey-Interscience Publication, USA, Limnological Research Center, University of Minnesota, 1022p. 1996.

THOMANN, R. V.; MUELLER, J. A. Principles of surface water quality modeling and control. Harper Internacional Edition, 1987. 644 p. 
TUNDISI, J. G. Reservoirs as complex sistems. Ciência e cultura, v. 48, n.5-6, pp383-387, 1996.

TUNDISI, J.G.; TUNDISI, T. M.; ROCHA, O. Ecossistemas de águas interiores. In: REBOUÇAS, A.C.; BRAGA, B.; TUNDISI, J.G. (ed.). Águas doces do Brasil: capital ecológico, uso e conservação. São Paulo: Escritura, 2006, p.153-192.

TUNDISI, J. G. Recursos hídricos no futuro: problemas e soluções. Estudos avançados, v.22, n.63, pp. 7-16, 2008. Disponível em: < http://www.scielo.br/scielo.php?script=sci_arttext\&pid=S0103-

$40142008000200002 \&$ Ing=pt\&nrm=iso\&tlng=pt>. Acesso em: 16 mar. 2015.

URAKAWA, M. K. Avaliação do conteúdo de metais e defensivos agrícolas na área de influência do reservatório de Biritiba-Mirim (SP). 2011. Dissertação de Mestrado Instituto de Geociências, Universidade de São Paulo. Disponível em: $<$ http://www.teses.usp.br/teses/disponiveis/44/44142/tde-06102015-114001/en.php>. Acesso em: 05 mar. 2015.

VON SPERLING, M.. Introdução à qualidade das águas e ao tratamento de esgotos. Belo Horizonte: Editora UFMG, 2005. 240p.

WALDMAN, M. Água e Metrópole: limite e expectativas do tempo. 2005. 406 f. Tese (Doutorado) - Departamento de Geografia da Faculdade de Filosofia, Letras e Ciências Humanas da Universidade de São Paulo - FFLCH/USP. São Paulo 2005.

WANG, X. H.; YIN, C. Q.; SHAN, B. Q. The role of diversified landscape buffer structures for water quality improvement in an agricultural watershed, North China. Agricultural Ecosystem And Environment, v.107, n.2, p.381-396, 2005.

WHATELY, M.; DINIZ, L. T. Água e esgoto na grande são Paulo: situação atual, nova lei de saneamento e programas governamentais propostos. São Paulo: Instituto Socioambiental, 2009. Disponível em: <http://www.socioambiental.org/banco_imagens/pdfs/10369.pdf>. Acesso em: 24 mar. 2015.

WIKIPÉDIA. Disponível em:

<https://upload.wikimedia.org/wikipedia/commons/c/c3/SaoPaulo_Municip_BiritibaMir im.svg>. Acesso em: 23 nov. 2014. 